INTER NATIONAL MONETARY FUND
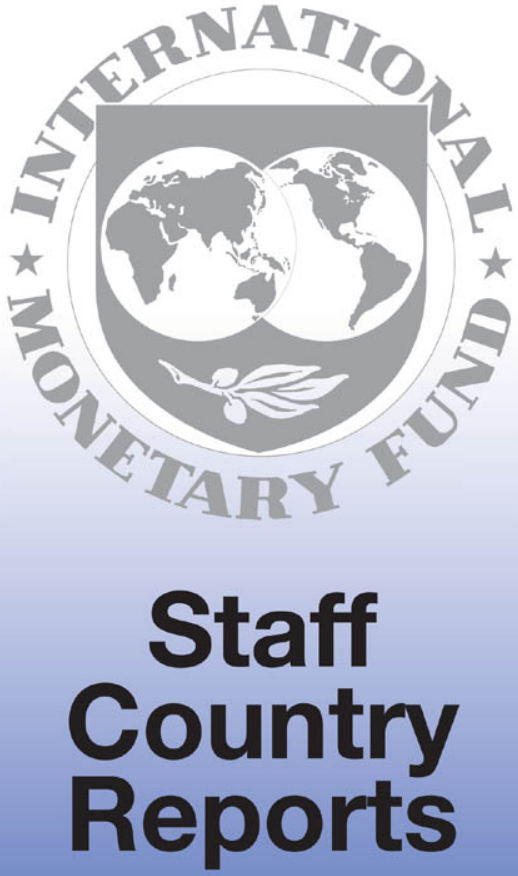


\title{
Cameroon: Staff Report for the 2009 Article IV Consultation and Request for disbursement Under the Rapid-Access Component of the Exogenous Shocks Facility
}

The following documents have been released and are included in this package:

- $\quad$ The staff report, prepared by a staff team of the IMF, following discussions that ended on April 9, 2009, with the officials of Cameroon on economic developments and policies. Based on information available at the time of these discussions, the staff report was completed on June 19, 2009. The views expressed in the staff report are those of the staff team and do not necessarily reflect the views of the Executive Board of the IMF.

- $\quad$ Debt Sustainability Analysis.

- $\quad$ A Press Release.

- A statement by the Executive Director for Cameroon.

The document listed below will be separately released.

Letter of Intent sent to the IMF by the authorities of Cameroon*

*Also included in Staff Report

The policy of publication of staff reports and other documents allows for the deletion of marketsensitive information.

\author{
Copies of this report are available to the public from \\ International Monetary Fund • Publication Services \\ $70019^{\text {th }}$ Street, N.W. • Washington, D.C. 20431 \\ Telephone: (202) 623-7430 • Telefax: (202) 623-7201 \\ E-mail: publications@imf.org Internet: http://www.imf.org
}

\section{International Monetary Fund \\ Washington, D.C.}


INTERNATIONAL MONETARY FUND

\title{
CAMEROON
}

\section{Staff Report for the 2009 Article IV Consultation and Request for Disbursement Under the Rapid-Access Component of the Exogenous Shocks Facility}

\author{
Prepared by the African Department \\ (In collaboration with other departments) \\ Approved by Mark Plant and Dhaneshwar Ghura
}

June 19, 2009

Discussions. The Article IV consultation discussions took place in Yaoundé and Douala, March 26-April 9 and in Washington, April 25-29. The mission met with Prime Minister Inoni, Finance Minister Menye, Economy Minister Motaze, several Cabinet members, BEAC National Director Mani, members of Parliament, donors, and representatives of civil society, labor unions, the private sector and the press. The team comprised Mr. Mecagni (head), Mr. Singh, Mr. Samake (all AFR), Mr. Klemm (FAD), Mr. Gemayel (SPR), Mr. Vandepeute (MCM), and Ms. Kabedi-Mbuyi (Resident Representative). Mr. Ghura joined the mission for the first few days. World Bank and African Development Bank staff participated in the discussions.

Consultation focus. The discussions focused on the impact of the global crisis on Cameroon's economy and appropriate responses that preserve debt sustainability. Although macroeconomic stability was strengthened under the recently completed PRGF arrangement and debt relief firmed up the country's debt sustainability, growth has remained too low to reduce poverty. The recent sizable exogenous shocks have considerably affected economic activity and the balance of payments, as well as tightened budgetary resources.

Policy advice. The staff report recommends (i) maintaining the 2009 budgeted spending plans to prevent a fiscal contraction in a year of declining economic growth; (ii) continuing efforts to achieve greater nonoil revenue mobilization, strengthen public expenditure management, and develop alternative sources of financing; (iii) creating a more conducive environment for private sector development through further improvement in transparency and governance, public enterprise reform, and trade liberalization; and (iv) closely monitoring the health of the banking system.

The authorities' position. The authorities broadly shared the staff's assessment, and are concerned about the pace of fiscal and external deterioration. They agreed that the 2009 budgetary spending plans should be protected in priority areas. In the absence of social safety nets, targeted measures could be taken in favor of sectors in distress. They also agreed that developments in the banking system should be monitored closely.

Request for support under the Exogenous Shocks Facility (ESF). The authorities are requesting support under the rapid-access component of the ESF (SDR 92.85 million, 50 percent of quota) to help the economy weather the impact of the shocks. The full amount would become available upon Board approval. 


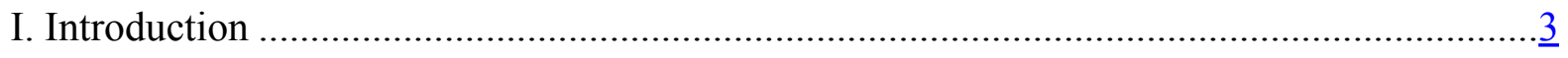

II. Recent Economic Developments and Outlook: Weathering the Global Crisis................... 7

A. Economic Developments in 2008 ...............................................................

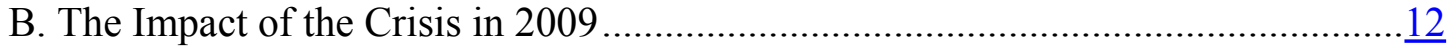

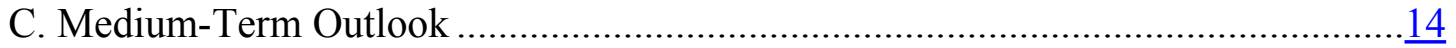

III. Policy Discussions: Responding to The Crisis and Reducing Vulnerabilities ..................15

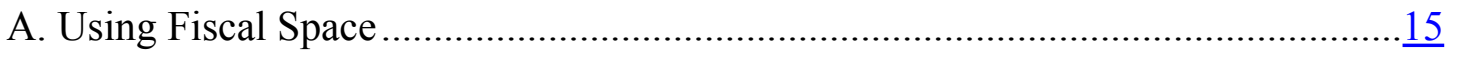

B. Raising Growth: Addressing the Bottlenecks ................................................19

C. Assuring the Stability of the Financial System ….............................................

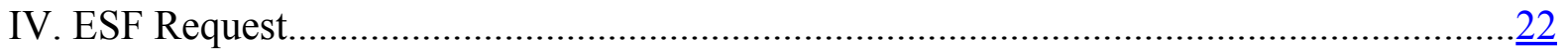

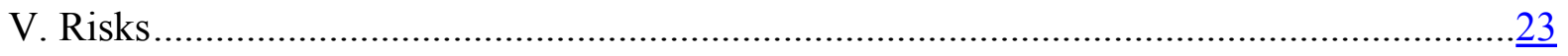

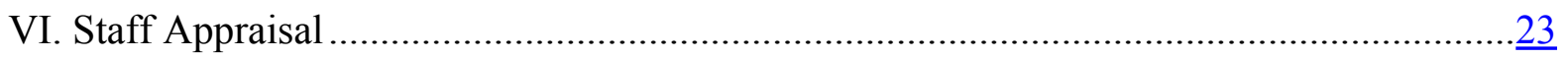

Boxes

1. Response to Previous Fund Advice .......................................................................... $\underline{6}$

2. External Competitiveness and Real Exchange Rate Assessment ................................... 9

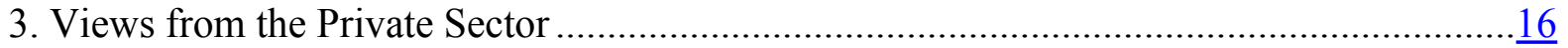

4. Infrastructure Bottlenecks to Growth and Challenges Ahead........................................20

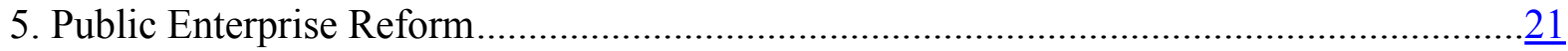

Figures

1. Key Achievements Under the PRGF, 2004-08 ............................................................. 4

2. Comparative Indicators ........................................................................................ $\frac{5}{2}$

3. Competitiveness-Survey Data Analysis, 2005-09 ................................................... 10

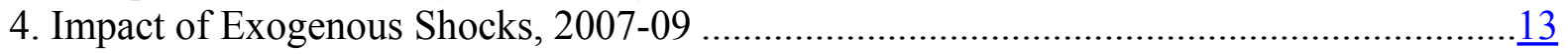

Tables

1. Selected Economic and Financial Indicators, 2007-12 _.............................................. 25

2. Balance of Payments, 2007-14 ................................................................................

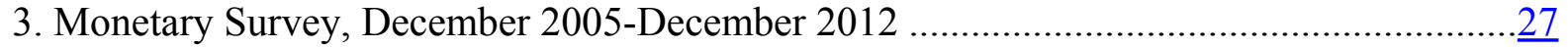

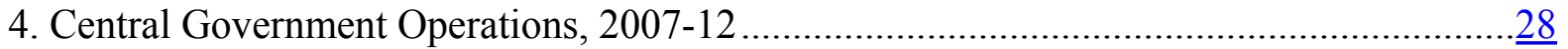

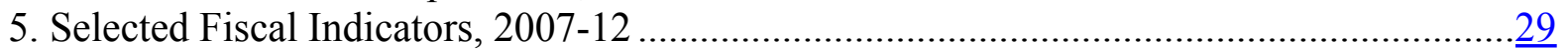

6. Indicators of Capacity to Repay the Fund, 2008-18 …............................................

Appendix

Letter of Intent 


\section{INTRODUCTION}

\section{Cameroon's macroeconomic performance was strengthened under the PRGF} arrangement completed in January 2009 (Figure 1 and Box 1). Debt relief in April 2006 under the HIPC Initiative helped firm up the country's debt sustainability, and create fiscal space for poverty-reducing spending. Public expenditure management is now more transparent and the financial sector stronger. ${ }^{1}$ Prudent management of oil earnings and revenue has allowed the authorities to accumulate government deposits at the regional central bank (BEAC) and to contribute to the currency union's pool of foreign exchange reserves, while raising investment and normalizing relations with creditors.

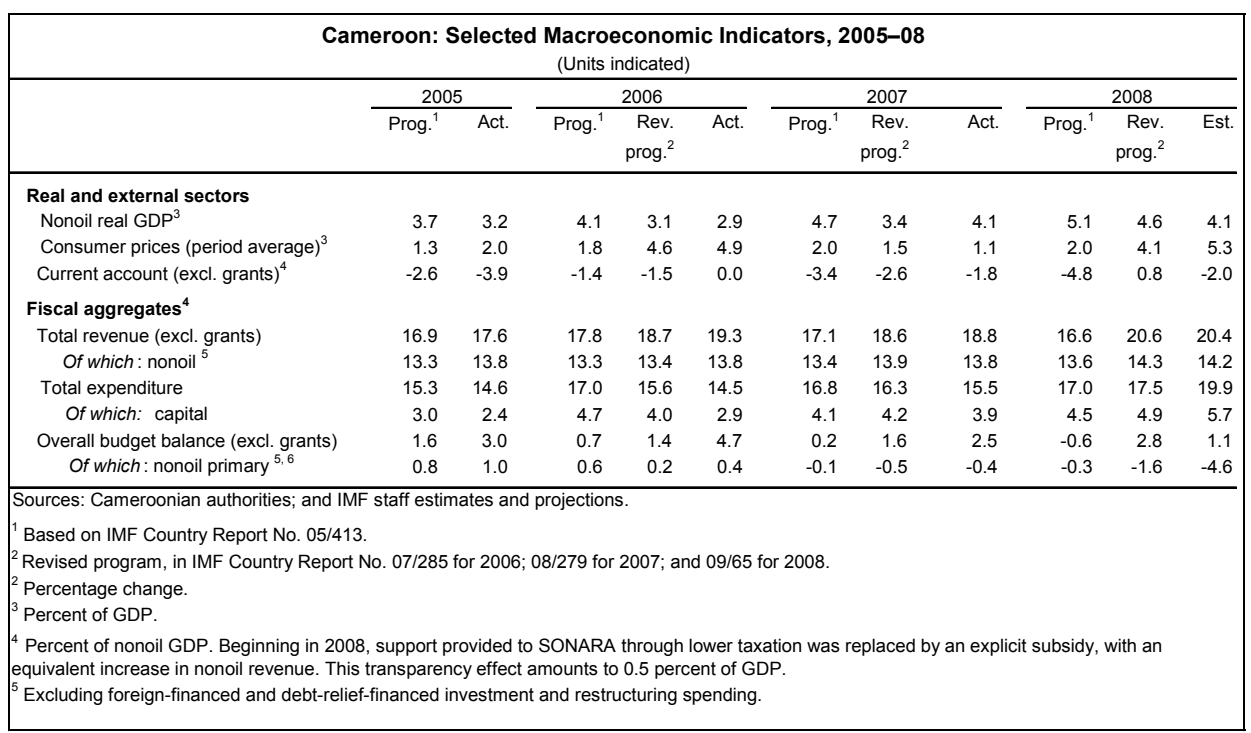

2. Despite these improvements, the economy remains vulnerable to commodity shocks, especially from oil, and reducing poverty is a challenge (Figure 2). Cameroon still relies heavily on commodities for its foreign exchange earnings and fiscal revenues, making it vulnerable to a decline in demand and prices for these products. Furthermore, the reforms carried out to date have not yet delivered the expected pickup in investment that would set the country on the higher growth path needed to reduce poverty. Reform of public

\begin{tabular}{|c|c|c|}
\hline \multicolumn{3}{|c|}{$\begin{array}{l}\text { Cameroon: Economic and Social Indicators, 2000-07 } \\
\text { (Period average, in units indicated) }\end{array}$} \\
\hline & Cameroon & $\begin{array}{r}\text { Lower-Middle- } \\
\text { Income } \\
\text { Economies } \\
\end{array}$ \\
\hline \multicolumn{3}{|l|}{ Economic indicators } \\
\hline GDP per capita ${ }^{1}$ & 658.8 & $1,070.4$ \\
\hline GDP per capita growth ${ }^{2}$ & 1.5 & 6.5 \\
\hline Gross domestic investment ${ }^{3}$ & 17.6 & 31.5 \\
\hline Foreign direct investment ${ }^{4}$ & 0.4 & 526.6 \\
\hline Credit to private sector $^{3}$ & 9.6 & 59.0 \\
\hline Trade in goods ${ }^{3}$ & 41.5 & 60.1 \\
\hline \multicolumn{3}{|l|}{ Social indicators } \\
\hline Adult literacy rate $^{5}$ & 67.9 & 88.9 \\
\hline Primary completion rate & 55.0 & 85.0 \\
\hline Secondary school enrollment ratio ${ }^{5}$ & 27.3 & 61.6 \\
\hline Life expectancy at birth, total (years) & 50.3 & 67.8 \\
\hline \multicolumn{3}{|c|}{$\begin{array}{l}\text { Source: World Bank Social Indicators Database; } \\
\text { and Cameroonian authorities. }\end{array}$} \\
\hline \multicolumn{3}{|l|}{${ }^{1}$ Constant 2000 US dollar. } \\
\hline \multicolumn{3}{|l|}{${ }^{2}$ Annual percent change. } \\
\hline \multicolumn{3}{|l|}{${ }^{3}$ Percent of GDP. } \\
\hline${ }^{4}$ US $\$$ billions. & & \\
\hline
\end{tabular}

\footnotetext{
${ }^{1}$ For instance, the budgetary support provided to SONARA (the national oil refinery) was made more transparent in 2008 by the adoption of a new fuel price formula that replaces lower taxation with higher explicit subsidies.
} 
Figure 1. Cameroon: Key Achievements Under the PRGF, 2004-08

HIPC/MDRI brought both external debt ...

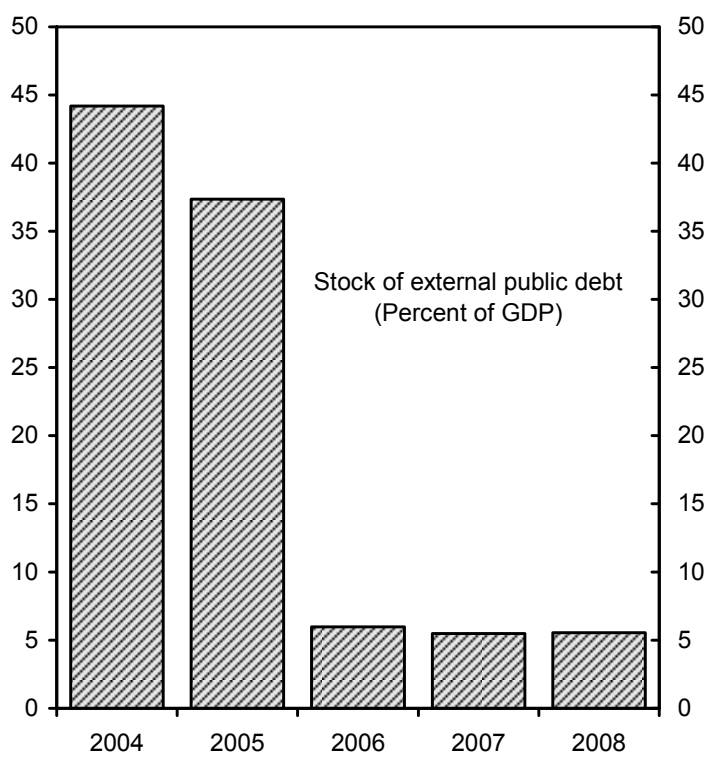

Prudent fiscal policy allowed the buildup of significant net government deposits...

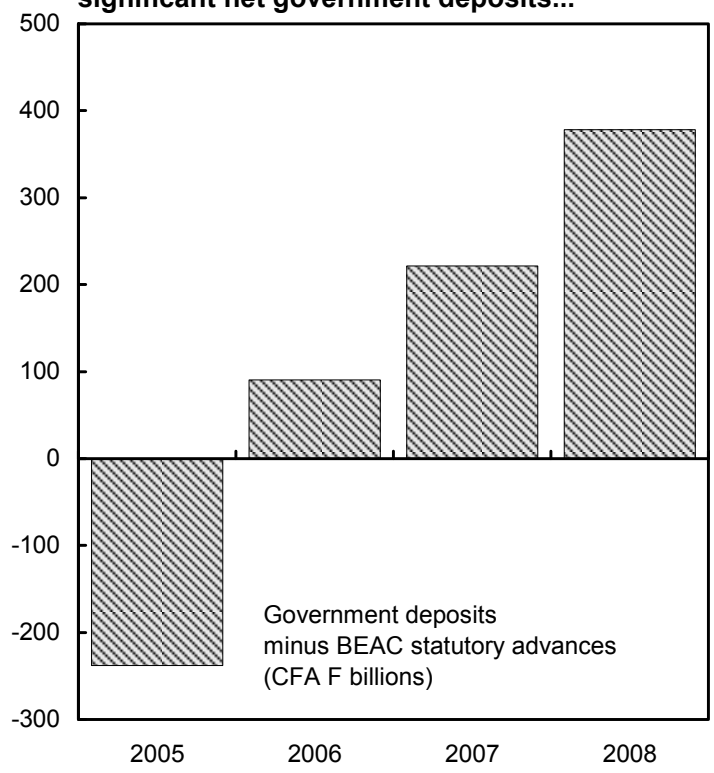

....and public debt to a sustainable level.

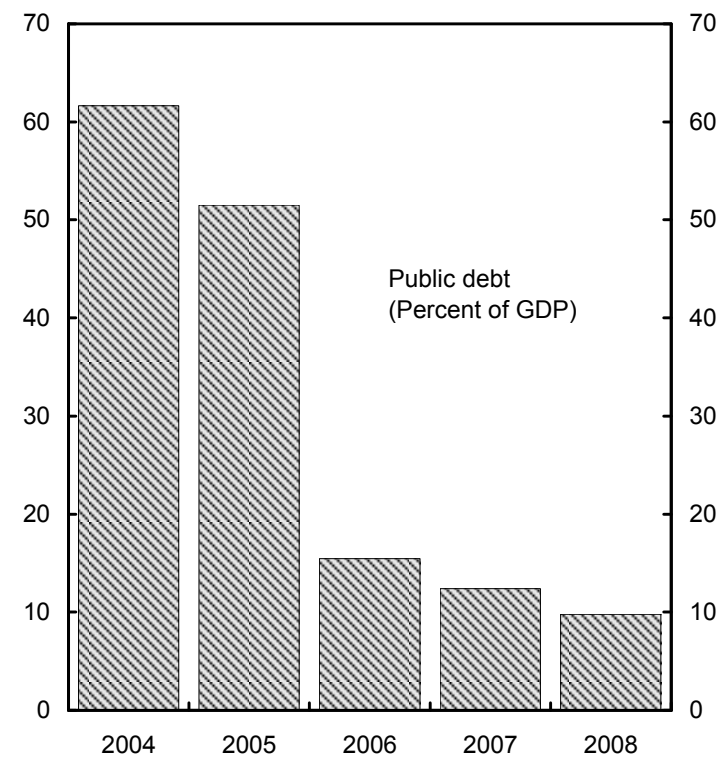

... and a contribution to the regional international reserves.

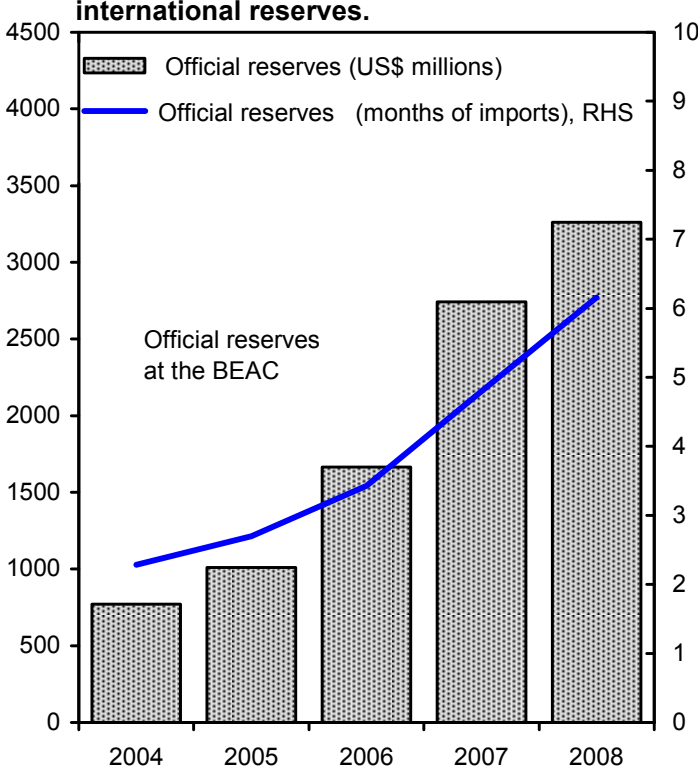

Sources: Cameroonian authorities; and IMF staff estimates. 
Figure 2. Cameroon: Comparative Indicators, 1980-2008

Cameroon is one of the largest economies in Africa ...

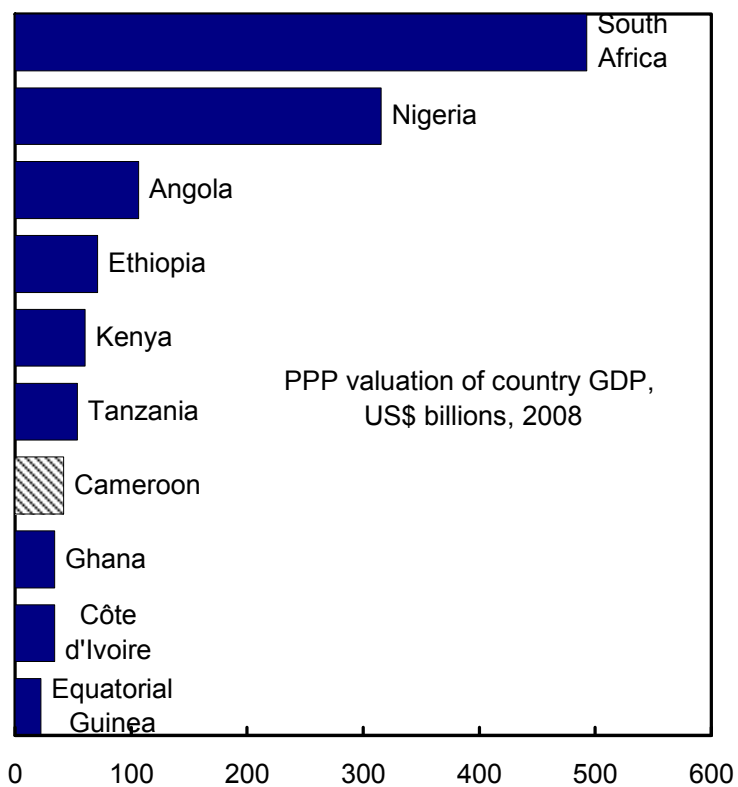

...and is relatively diversified.

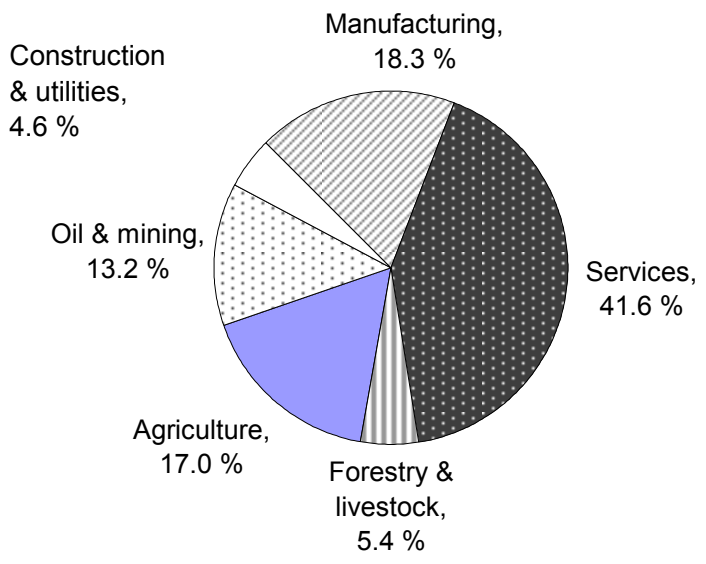

2008 GDP breakdown, percent of total

But oil still plays an important role... (2008, in percent)
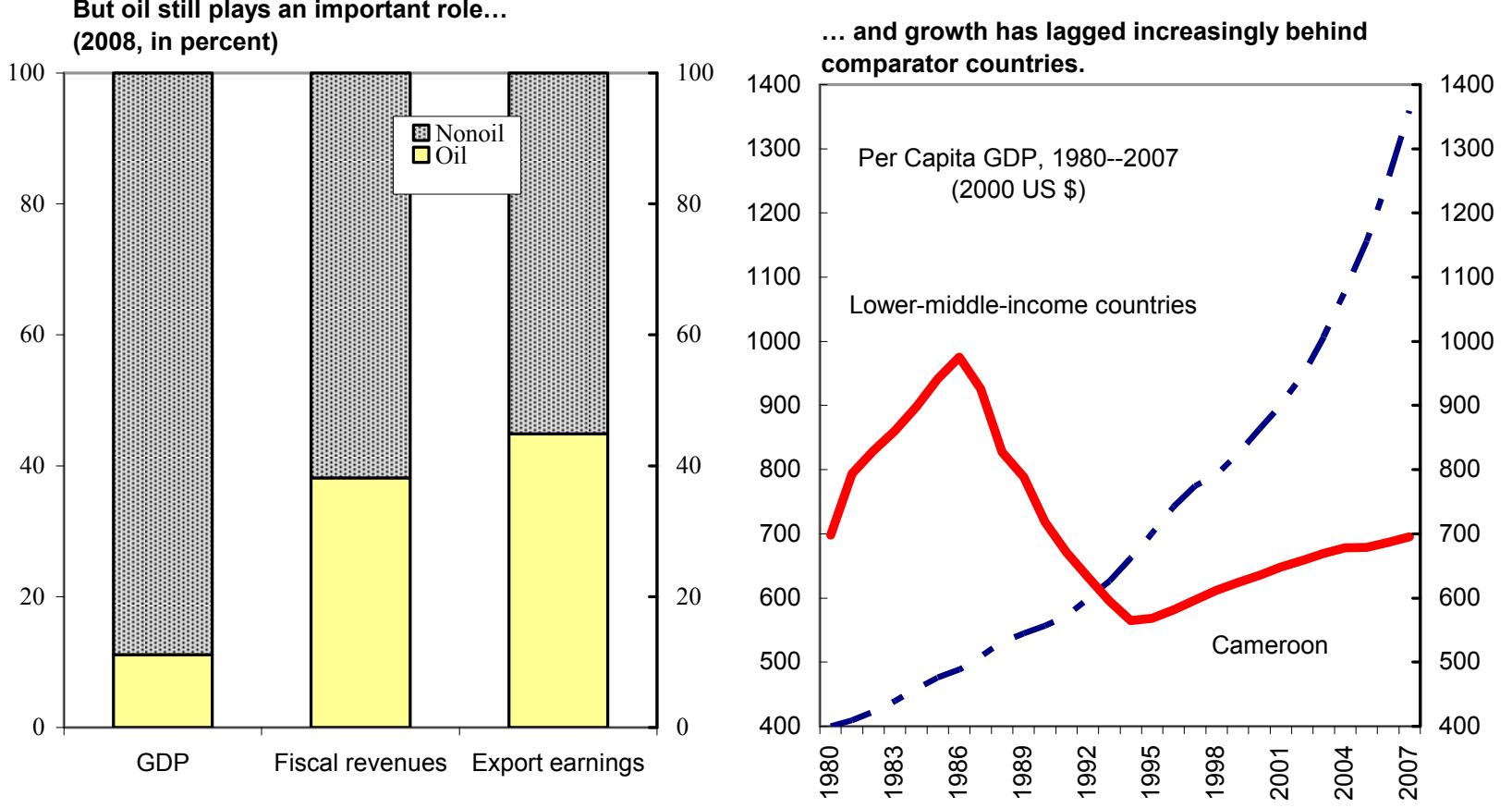

Sources: Cameroonian authorities; and IMF staff estimates. 
enterprises has been slower than expected under the PRGF arrangement, and limited infrastructure and an unfavorable business environment continue to hamper economic growth. As a result, Cameroon's per capita real GDP has trailed comparator countries and the population living below the poverty threshold has remained virtually unchanged at 40 percent since 2001. On its current trajectory, Cameroon is unlikely to meet the MDGs.

\begin{tabular}{|c|c|c|}
\hline \multicolumn{3}{|c|}{ Box 1. Cameroon: Response to Previous Fund Advice } \\
\hline Policy Area & $\begin{array}{l}\text { Staff Recommendations During } \\
\text { the } 2007 \text { Article IV Consultation }\end{array}$ & Implementation/Outcome \\
\hline $\begin{array}{l}\text { Fiscal policy and } \\
\text { management }\end{array}$ & $\begin{array}{l}\text { Raise nonoil revenues; contain } \\
\text { expenditures while promoting } \\
\text { priority outlays; improve public } \\
\text { finance management; and ensure } \\
\text { prudent debt management. }\end{array}$ & $\begin{array}{l}\text { Despite reforms in tax and customs } \\
\text { administrations, nonoil revenues stagnated as a } \\
\text { share of nonoil GDP (once adjusted for } \\
\text { transparency effects). }{ }^{2} \text { Priority spending, } \\
\text { including investment, increased. A new public } \\
\text { finance system law was adopted in } 2007 \text { and is } \\
\text { being phased in over five years. Only } \\
\text { concessional debt was contracted and budgetary } \\
\text { surpluses were used to reduce domestic debt. }\end{array}$ \\
\hline $\begin{array}{l}\text { Public enterprise } \\
\text { reform }\end{array}$ & $\begin{array}{l}\text { Take actions to reduce government } \\
\text { participation in public enterprises } \\
\text { and improve services. }\end{array}$ & $\begin{array}{l}\text { Although the water company is now under a } \\
\text { management contract, the restructuring of the } \\
\text { airline and telephone companies has yet to be } \\
\text { completed. }\end{array}$ \\
\hline $\begin{array}{l}\text { Private sector } \\
\text { development }\end{array}$ & $\begin{array}{l}\text { Improve the business environment } \\
\text { in order to boost growth. }\end{array}$ & $\begin{array}{l}\text { Spending on infrastructure increased. Limited } \\
\text { progress was made toward the removal of } \\
\text { impediments to trade within CEMAC. An action } \\
\text { plan has been prepared to deepen financial } \\
\text { intermediation on the basis of the } 2007 \text { FSAP } \\
\text { recommendations. The government is taking } \\
\text { steps to strengthen the judiciary and fight } \\
\text { corruption. }\end{array}$ \\
\hline
\end{tabular}

3. The authorities are eager to set the economy on a higher-growth path that can lower poverty, though they realize that the global crisis will make this task more challenging. Even before the global crisis, the authorities had stressed their resolve to revive economic activity, while preserving macroeconomic stability and debt sustainability. They had accelerated priority expenditure, refocused capital spending on infrastructure and agriculture, and stepped up efforts to mobilize nonoil revenue. They are preparing an economic program in the context of a new poverty reduction strategy (PRS). The global slowdown has made this policy agenda even more urgent.

\footnotetext{
${ }^{2}$ See footnote 1 .
} 


\section{Social tensions that arose last year have abated and the political situation is}

stable. Dissatisfaction with rising costs for food and fuel amid discussions of changes to the constitution had caused unrest in early 2008. Fiscal measures adopted by the authorities in March 2008 - customs duty exemptions for some necessities, a fuel price freeze amid high oil prices, and salary increases for civil servants - helped to reduce social tensions and price pressures. The impact of the global crisis carries a risk of severe social implications, however. In April 2008, Parliament amended the constitution to eliminate the two-term limit for presidents.

\section{RECENT ECONOMIC DEVELOPMENTS AND OUTLOOK-WEATHERING THE GLOBAL CRISIS}

\section{A. Economic Developments in $\mathbf{2 0 0 8}$}

\section{In 2008, the global downturn had little effect on Cameroon's economic activity} (Table 1). Despite a contraction in oil output, real GDP grew by about $3 \frac{1}{2}$ percent driven by the continued pickup in nonoil economic activity, including agriculture. Slower external demand has, however, lowered timber and cotton exports. In addition, increased imports resulting from high food prices kept the current account in deficit (Table 2), despite high oil prices for most of the year. Nonetheless, the overall external position remained in surplus, allowing a further contribution to the regional pool of foreign exchange reserves.
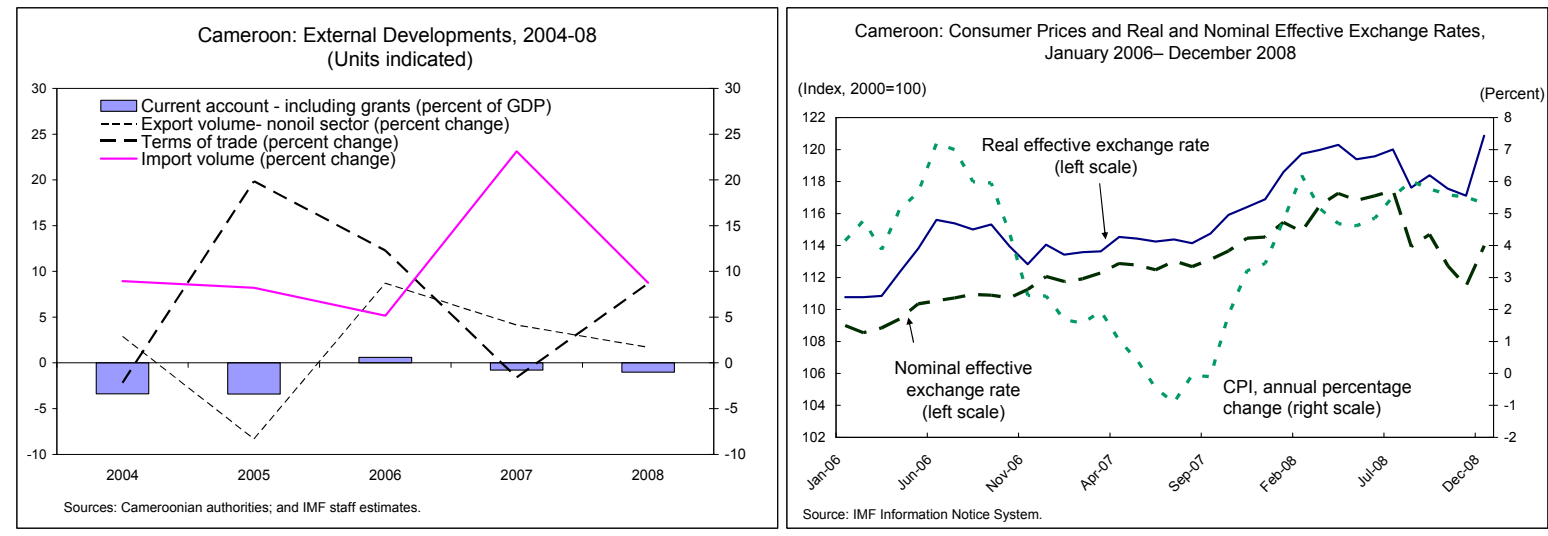

6. Fuel and food continued to dominate price developments. Despite the fuel price freeze and lower taxation of some staple goods, inflation increased in 2008. Headline inflation reached 5.3 percent (year-on-year) in December 2008 (compared to 3.4 percent a year earlier), but core inflation remained stable at about $4 \frac{1}{2}$ percent. Combined with a recent strengthening of the euro, these developments contributed to an appreciation of the real effective exchange rate (REER). ${ }^{3}$ While the REER is broadly in line with fundamentals,

\footnotetext{
${ }^{3}$ Cameroon is a member of the Central African Economic and Monetary Community (CEMAC). The region's currency (the CFA franc) is pegged to the euro.
} 


\section{Box 2. External Competitiveness and Real Exchange Rate Assessment}

Staff's analysis suggests that Cameroon's real effective exchange rate (REER) is in line with its equilibrium level. Survey data indicate, however, that the country's competitiveness continues to suffer from several nonprice factors, principally related to a poor business environment.

Methodology. Five approaches were used to assess Cameroon's real effective exchange rate (REER) and competitiveness: the three CGER methodologies complemented by a Cameroonspecific multivariate reduced-form model (see Table) and survey data analysis.

\section{The macroeconomic balance approach} estimates a current account norm (or equilibrium current account) based on economic fundamentals for Cameroon relative to its trading partners. The analysis shows that a 4 percent (backward) to 3 percent (forward) real depreciation would be required to close the gap between the underlying current account, which strips the actual current account of all temporary factors, and the current account norm.

2. The external sustainability approach calculates the current account that stabilizes the net foreign assets (NFA)-to-GDP ratio at the end-2008 level. Based on medium-term growth and inflation projections and estimated trade elasticities, the analysis suggests that the REER would need to depreciate by 6 percent (backward) to 8 percent (forward) to stabilize NFA.

3. Two reduced-form Fundamental Equilibrium Exchange Rate assessments were conducted: the CGER panel-based and the country-specific multivariate vector error correction model. These methodologies assume that the equilibrium REER is related to a set of fundamental factors: terms of trade, productivity, investment, government consumption, NFA, and trade openness. They produce a range of results from 0.2 percent undervaluation (CGER panel-based) to 7 percent overvaluation (country-specific model).

4. Survey data analysis, which is a complement to the above quantitative assessments, provides information on structural obstacles to competitiveness. For the last two years the Global Competitiveness Index (GCI) and the World Bank Doing Business reports have ranked Cameroon in the bottom quartile. The country's share in world nonoil products markets has been declining for the past decade (see text figure). These observations suggest an erosion in Cameroon's competitiveness. 
Figure 3. Cameroon: Competitiveness-Survey Data Analysis, 2008-09
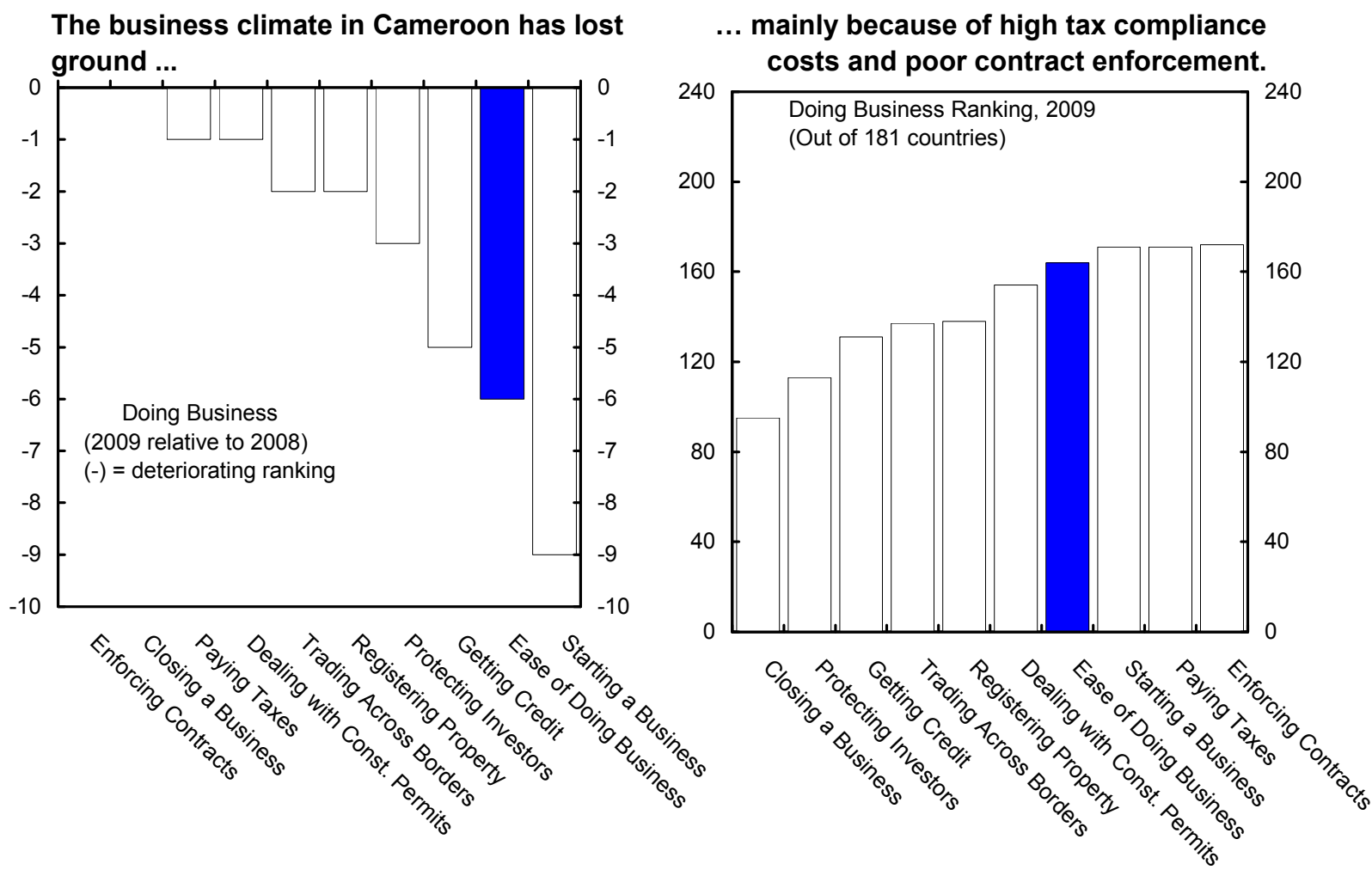

As a result, the country remains in the bottom quartile ranking.

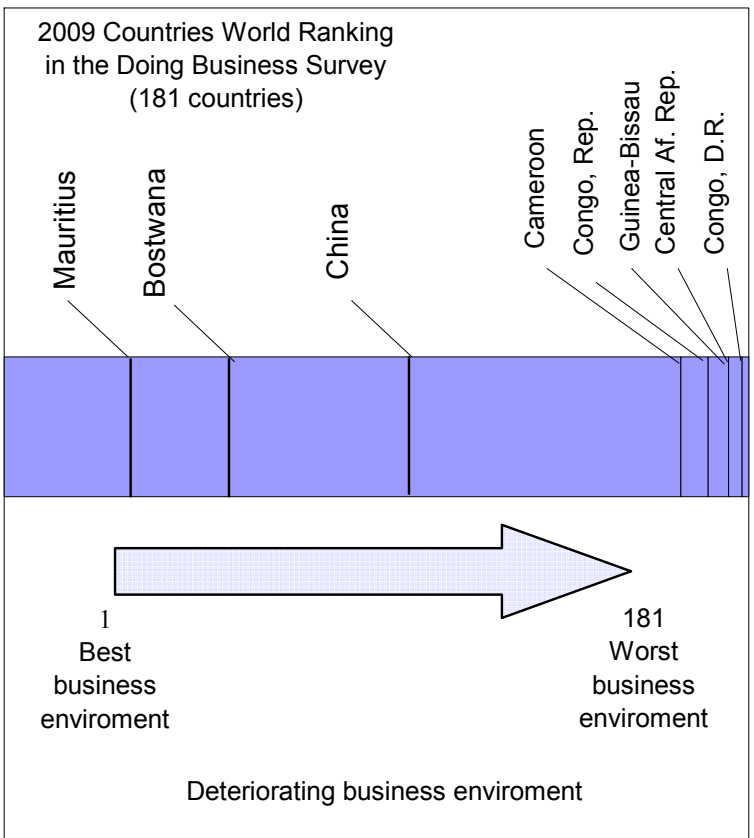

\begin{tabular}{|c|c|c|c|c|}
\hline & $\begin{array}{r}\text { Doing } \\
\text { Business } \\
(\text { Overall } \\
\text { rank) }{ }^{1} \\
\end{array}$ & $\begin{array}{r}\text { Days to } \\
\text { Acquire } \\
\text { Licenses } \\
\end{array}$ & $\begin{array}{r}\text { Cost of } \\
\text { Registering } \\
\text { Property }^{2} \\
\end{array}$ & $\begin{array}{l}\text { Days for } \\
\text { Enforcing } \\
\text { Contracts } \\
\end{array}$ \\
\hline Cameroon & 164 & 426 & 18 & 800 \\
\hline Philippines & 140 & 203 & 4 & 842 \\
\hline Indonesia & 129 & 176 & 11 & 570 \\
\hline China & 83 & 336 & 3 & 406 \\
\hline Botswana & 38 & 167 & 5 & 987 \\
\hline Mauritius & 24 & 107 & 11 & 750 \\
\hline Thailand & 13 & 156 & 1 & 479 \\
\hline Other CEMAC & 170 & 200 & 15 & 717 \\
\hline Sub-Saharan Africa & 138 & 271 & 11 & 660 \\
\hline LMIC $^{3}$ & 103 & 214 & 6 & 664 \\
\hline \multicolumn{5}{|c|}{ Source: Doing Business Database, 2009 (World Bank) } \\
\hline \multicolumn{5}{|c|}{$\begin{array}{l}{ }^{1} \text { Indicates ranking out of } 181 \text { countries } \\
\text { (lower number = higher ranking). }\end{array}$} \\
\hline
\end{tabular}

Source: The World Bank, Doing Business 2008 and 2009. 
of the freeze in fuel prices were not fully paid, resulting in arrears towards this company of about 1 percent of GDP.

9. Money growth slowed in 2008. The continued accumulation of government deposits and slower expansion in net foreign assets kept money growth contained (Table 3). Meanwhile, credit to the private sector picked up, expanding by about 20 percent (year-on-year) as a number of investment projects were initiated. This reduced the amount of excess liquidity in the banking system. Despite the rapid credit expansion, observance of regional prudential norms has improved. In addition, an agreement was reached with a strategic partner to take over one of the two intervened banks, with discussions ongoing for the other one. At this stage, the regional supervisory agency

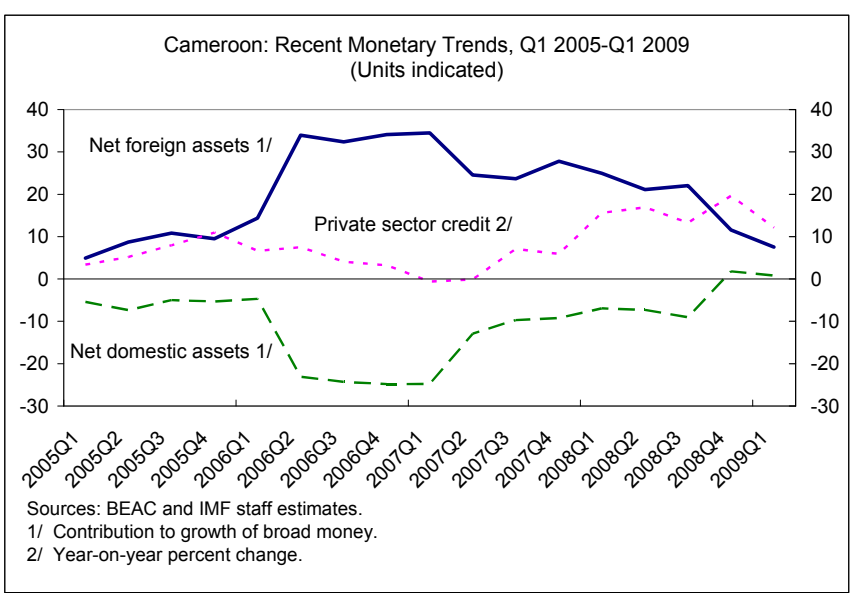
(COBAC) sees no widespread evidence of distress in the banking sector. Pockets of vulnerability exist, however, compliance with capital requirements and credit exposure limits remaining weak in some instances.

\begin{tabular}{|c|c|c|c|c|c|c|}
\hline \multicolumn{7}{|c|}{$\begin{array}{c}\text { Cameroon: Banking System Indicators } \\
\text { (Units indicated) }\end{array}$} \\
\hline & 2006 & Feb-2007 & Feb-2008 & Aug-2008 & Nov-2008 & Feb-2009 \\
\hline \multicolumn{7}{|l|}{ Violations of main prudential ratios } \\
\hline Capital adequacy ratio & 4 & 4 & 3 & 3 & 4 & 2 \\
\hline Limit on single large exposure $^{1}$ & 6 & 7 & 6 & 5 & 6 & 4 \\
\hline Limit on global risk exposure ${ }^{2}$ & & 3 & 3 & 3 & 3 & 2 \\
\hline Fixed assets coverage 3 & 6 & 5 & 5 & 3 & 3 & 2 \\
\hline Liquidity ${ }^{4}$ & 0 & 0 & 1 & 0 & 0 & 0 \\
\hline Excess liquidity $^{5}$ & $\ldots$ & $\ldots$ & 35 & 31 & 23 & 27 \\
\hline Maturity transformation ${ }^{6}$ & 4 & 2 & 2 & 2 & 2 & 1 \\
\hline Minimum capital' & 2 & 2 & 2 & 2 & 2 & 1 \\
\hline Exposure to the affiliated ${ }^{\gamma}$ & & 2 & 3 & 2 & 2 & 1 \\
\hline Number of banks & 11 & 11 & 12 & 12 & 12 & 12 \\
\hline \multicolumn{7}{|l|}{ Quality of loan portfolio } \\
\hline Nonperforming loans (percent of gross loans) & 12.4 & 13.6 & 13.3 & 13.2 & 11.8 & 12.1 \\
\hline Provisioning (percent of nonperforming loans) & 89.5 & 83.7 & 89.8 & 86.2 & 89.1 & 91.1 \\
\hline \multicolumn{7}{|c|}{$\begin{array}{l}\text { Sources: Banking Commission of Central Africa (COBAC) and IMF staff calculations. } \\
{ }^{1} \text { Single large exposure is limited to } 45 \text { percent. } \\
2 \text { The sum of single large exposure above } 15 \text { percent cannot be more than } 8 \text { times the permanent resources. } \\
{ }^{3} \text { Net capital and other permanent resources over fixed assets must be equal or above } 100 \text { percent. } \\
{ }^{4} \text { Short term assets (up to one month remaining maturity) over short-term liabilities (up to one month remaining } \\
\text { maturity) must be equal or above minimum } 100 \text { percent. } \\
\\
{ }^{6} \text { Excess liquidity: Banks' total reserves minus reserve requirements over deposits. } \\
{ }^{5} \text { Financing of long-term assets (more than five years) over long-term liabilities (more than five years) must be at least } \\
{ }^{7} \text { Minimum capital for Cameroon : CFAF } 1 \text { billion. } \\
{ }^{8} \text { Credit to shareholders, administrators, and managers must be below } 15 \text { percent. }\end{array}$} \\
\hline
\end{tabular}




\section{B. The Impact of the Crisis in 2009}

10. The global crisis is expected to take a considerably greater toll in 2009 (Figure 4). Although Cameroon's banking sector is not directly exposed to the global financial turmoil, Cameroon's economic activity is expected to be adversely affected through the following channels:

- World prices for Cameroon's main export commodities (e.g., oil) have declined, leading to a sharp deterioration in the terms of trade (about 20 percent).

- Slower world demand has had adverse effects on timber, rubber, cotton, and to a lesser extent, aluminum, which was also affected by input constraints.

- Given the tight international liquidity conditions, financing for some large investment projects has been delayed, particularly in the energy, aluminum, and mining sectors, reducing the inflow of foreign capital.

- Remittances (although they amount only to about 0.8 percent of GDP) are expected to decline.

11. As a result, economic activity, the external position, and the fiscal accounts are being severely affected. Economic growth is projected to slow by 1 percentage point, to 2.4 percent in 2009 , with risks on the downside. The estimated net impact of the shocks on balance of payments flows is about 7.6 percent of GDP. Offsetting developments in other items bring the deterioration in the balance of payments to about 6 percentage points of GDP in 2008-09. This would imply a sharp decline in the country's notional foreign exchange reserves at the BEAC from 6.2 months of imports in 2008 to about 4.5 months of imports by end-2009 in the absence of additional financing. Similarly, the overall fiscal surplus of 2 percent of GDP (including grants) observed in 2008 is expected to turn into a deficit in 2009 of close to 1 percent of GDP.

\begin{tabular}{|c|c|c|}
\hline \multicolumn{3}{|c|}{$\begin{array}{c}\text { Estimated Net Impact of Exogenous } \\
\text { Shocks on Cameroon's } \\
\text { Balance of Payments }\end{array}$} \\
\hline & \multicolumn{2}{|c|}{$\Delta 2008-09$} \\
\hline & $\begin{array}{r}\text { CFAF } \\
\text { (billion) }\end{array}$ & $\begin{array}{l}\text { Percent } \\
\text { of GDP }\end{array}$ \\
\hline Exports & $-1,016.6$ & -9.9 \\
\hline Oil & -405.6 & -3.9 \\
\hline Non-oil & -611.0 & -5.9 \\
\hline Imports & 165.1 & 1.6 \\
\hline Income & 155.0 & 1.5 \\
\hline Remittances & -5.3 & -0.1 \\
\hline Capital flows & -86.3 & -0.8 \\
\hline Total & -788.2 & -7.6 \\
\hline
\end{tabular}


Figure 4. Cameroon: Impact of Exogenous Shocks, 2007-09¹

Commodity prices have declined and risks remain on the downside.

As a result, Cameroon's terms of trade are expected to deteriorate substantially in 2009.
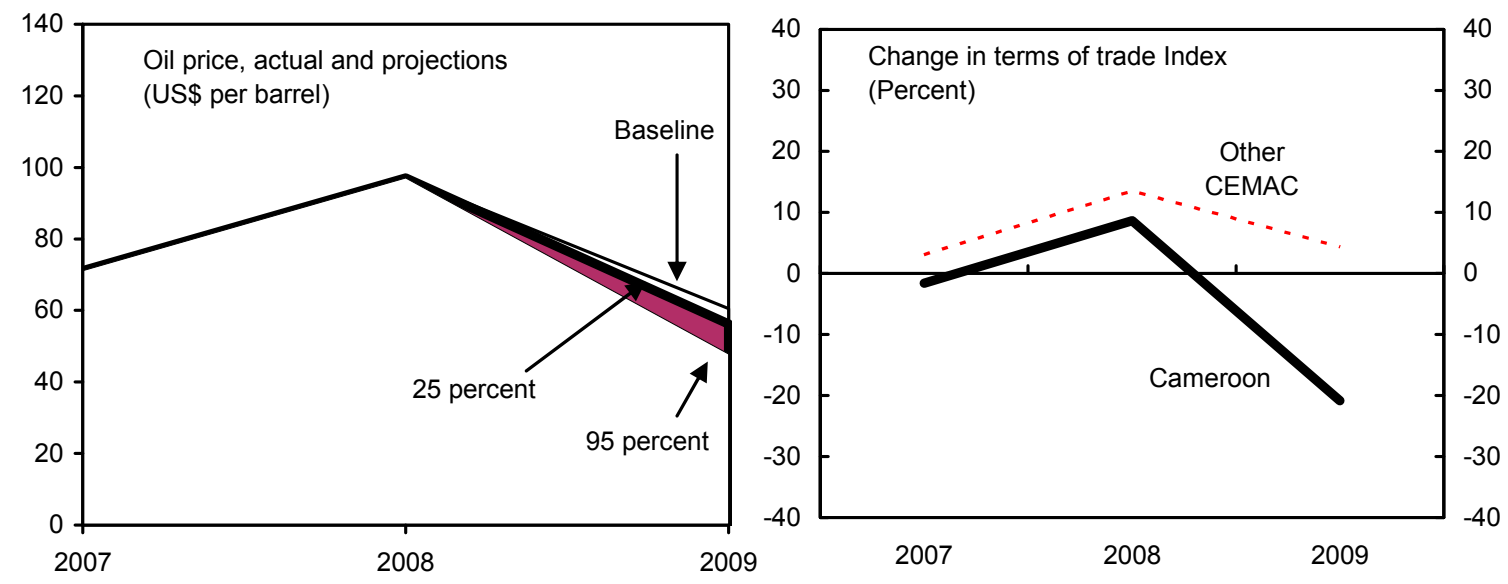

Lower external demand is expected to slow real GDP growth.
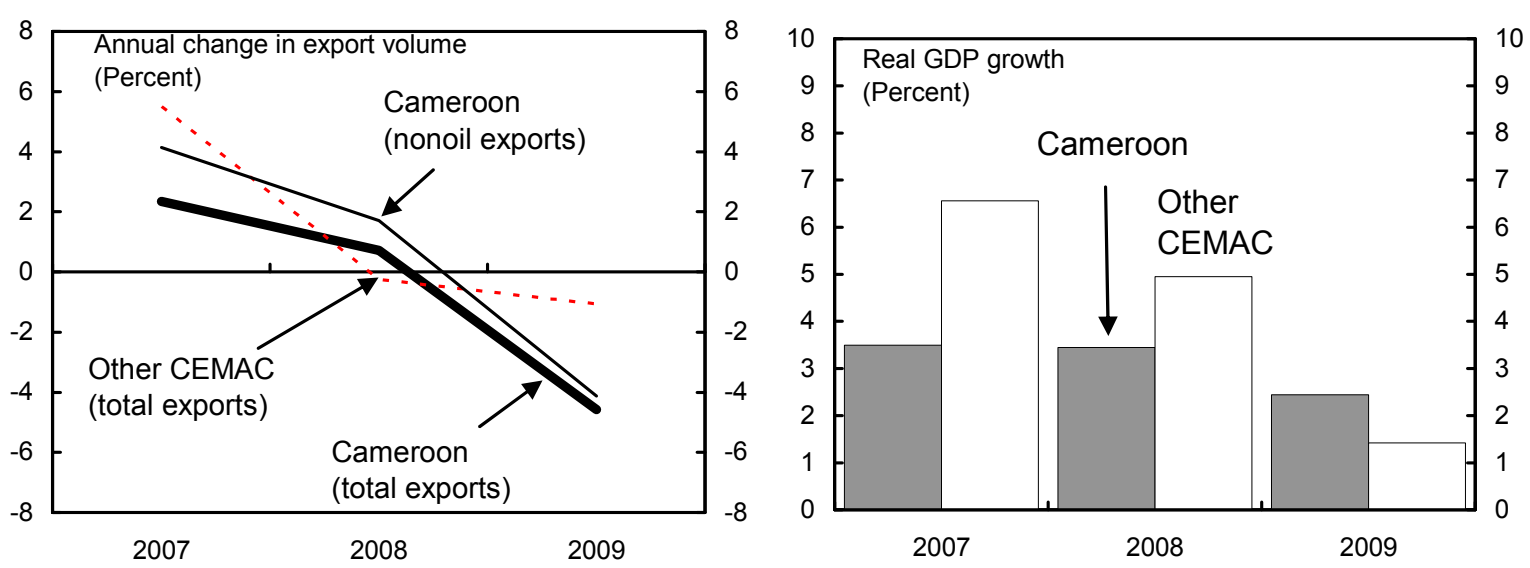

The current account is projected to further widen and the overall fiscal position turn into a deficit.

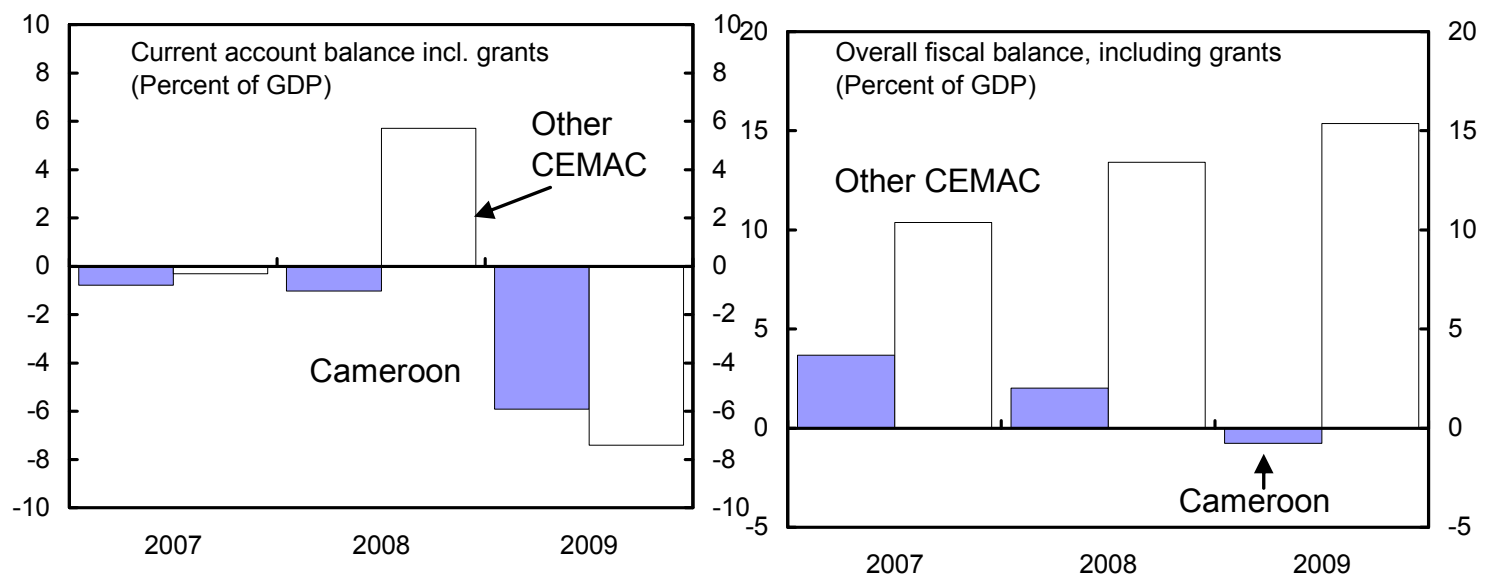

Source: Cameroonian authorities; and IMF staff estimates and projections.

${ }^{1}$ CEMAC averages exclude Cameroon. 


\section{Medium-Term Outlook}

\section{Cameroon's medium-term economic outlook has also been revised downward.}

The deterioration in Cameroon's terms of trade is expected to be partially reversed in 2010 and the country's export outlook should gradually improve as the global economy recovers. Nevertheless, delays in implementing important infrastructure projects will continue to weigh adversely on the country's medium-term economic prospects. Against this background,

- Nonoil real GDP growth is expected to be lower than previously projected by about $1 \frac{1}{2}$ percentage points per year.

- Fiscal oil revenues have been revised slightly upwards with recent investment temporarily raising oil production in 2011 and 2012.

- Nonoil revenues have been revised downward, because of the weaker growth projections.

- The overall fiscal balance will turn into a modest deficit of less than one percent of GDP and the nonoil primary deficit will widen broadly by the same magnitude.

- The current account deficit, widening by about 2 percentage points of GDP because of the global crisis, will persist over the medium term.

- On the positive side, price pressures on food and fuel seen last year have subsided.

\begin{tabular}{|c|c|c|c|c|c|c|c|c|c|}
\hline \multicolumn{10}{|c|}{$\begin{array}{l}\text { Cameroon: Selected Macroeconomic Indicators, 2008-14 } \\
\text { (Units indicated) }\end{array}$} \\
\hline & \multirow{2}{*}{$\frac{2008}{\text { Est. }}$} & \multicolumn{2}{|c|}{ Baseline $^{1}$} & \multicolumn{6}{|c|}{ Updated Scenario } \\
\hline & & 2009 & 2010 & 2009 & 2010 & 2011 & 2012 & 2013 & 2014 \\
\hline \multicolumn{10}{|l|}{ Economic growth and prices } \\
\hline Nonoil real GDP growth ${ }^{2}$ & 4.1 & 4.6 & 4.9 & 3.1 & 3.3 & 3.6 & 3.9 & 4.9 & 5.6 \\
\hline Consumer prices (period average) ${ }^{2}$ & 5.3 & 2.6 & 2.0 & 2.7 & 2.0 & 2.0 & 2.0 & 2.0 & 2.0 \\
\hline Oil export price (US\$ per barrel) & 94.3 & 58.0 & 65.0 & 57.5 & 71.5 & 75.0 & 77.0 & 78.3 & 79.5 \\
\hline Oil output (thousands of barrels a day) & 86 & 85 & 84 & 78 & 70 & 79 & 87 & 85 & 83 \\
\hline \multicolumn{10}{|l|}{ Fiscal aggregates $^{3}$} \\
\hline Total revenue & 21.3 & 19.0 & 18.3 & 19.2 & 18.1 & 19.1 & 19.4 & 19.1 & 18.9 \\
\hline Of which: oil & 7.8 & 4.1 & 3.3 & 4.9 & 4.0 & 4.9 & 5.3 & 4.9 & 4.6 \\
\hline nonoil $^{4}$ & 14.2 & 14.8 & 15.1 & 14.2 & 14.3 & 14.6 & 14.8 & 14.9 & 15.0 \\
\hline Total expenditure & 19.9 & 18.8 & 18.5 & 18.7 & 18.7 & 18.7 & 18.8 & 19.0 & 19.0 \\
\hline Of which: noninterest current & 14.0 & 12.8 & 12.3 & 12.6 & 12.4 & 12.1 & 11.9 & 11.9 & 11.9 \\
\hline capital & 5.7 & 5.6 & 5.8 & 5.7 & 6.0 & 6.3 & 6.6 & 6.8 & 6.9 \\
\hline Overall budget balance (incl. grants) & 2.0 & 0.0 & -0.4 & -0.8 & -0.7 & 0.2 & 0.4 & 0.0 & -0.2 \\
\hline Nonoil primary fiscal balance ${ }^{4}$ & -6.8 & -3.8 & -3.4 & -4.3 & -4.5 & -4.6 & -4.8 & -4.9 & -4.8 \\
\hline Nonoil current balance $^{4}$ & -0.8 & 1.0 & 1.8 & 1.4 & 1.6 & 1.9 & 2.1 & 2.2 & 2.4 \\
\hline \multicolumn{10}{|l|}{ External sector } \\
\hline Current account (incl. grants) & -1.0 & -4.0 & -4.0 & -5.9 & -4.2 & -3.6 & -3.3 & -3.2 & -3.1 \\
\hline Terms of trade ${ }^{2}$ & 8.7 & -30.7 & -2.4 & -20.9 & 12.5 & 4.4 & 2.3 & -4.1 & -3.9 \\
\hline \multicolumn{10}{|l|}{ Memorandum items: } \\
\hline Oil revenue (alternative scenario) ${ }^{5}$ & $\ldots$ & $\ldots$ & $\ldots$ & 4.0 & 3.0 & 4.0 & 4.3 & 4.0 & 3.7 \\
\hline \multicolumn{10}{|c|}{ Sources: Cameroonian authorities; and IMF staff estimates and projections. } \\
\hline $\begin{array}{l}{ }^{1} \text { Based on IMF Country Report No. 09/65. } \\
{ }^{2} \text { Percentage change. } \\
{ }^{3} \text { Percent of GDP. } \\
{ }^{4} \text { Percent of nonoil GDP. } \\
{ }^{5} \text { Using WEO oil prices minus US } \$ 10 \text { per b }\end{array}$ & & & & & & & & & \\
\hline
\end{tabular}




\section{Policy Discussions-Responding to The Crisis AND REDUCING VULNERABILITIES}

\section{A key challenge confronting the Cameroonian authorities is to address the} impact of the global crisis within a framework that maintains fiscal and external sustainability while leaving room to boost growth. The authorities recognize that the impact of the global crisis underscores the continued vulnerability of Cameroon's economy to external shocks, especially fluctuations in demand and prices for its key commodities. They have taken immediate actions to shelter the economy in the short run and are committed to reforms that would increase resilience to external shocks over time. Against this backdrop, the Article IV consultation discussions centered on three key areas:

- Using the available fiscal space;

- Reducing the obstacles to growth; and

- Ensuring the stability of the financial sector.

\section{A. Using Fiscal Space}

\section{The authorities and staff agreed that in the short run fiscal policy should help} cushion the economy from the impact of the global crisis, despite the tighter financing conditions. The private sector has expressed concerns about the potential social costs of the current crisis and is calling for immediate action in favor of sectors in distress (Box 3). In this context, the authorities agreed to avoid to the extent possible a fiscal contraction in a year of significant decline in growth. In this regard, they are preparing a supplementary budget which would allow for some targeted support, a minor increase in domestic investment, and a larger allocation for the clearance of arrears. The level of the 2009 budgeted spending would be maintained (with the exception of fuel subsidies). The implied fiscal stance would remain broadly unchanged in 2009 compared to $2008 .^{6}$

- In the absence of social safety nets, targeted measures will be taken to protect sectors facing particular difficulties. In the forestry sector, cascading has been reduced by eliminating some taxes and the annual timber royalty could be reduced to reflect lower timber prices. In the agriculture sector, given the tight financial situation of many small producers, the authorities are moving to provide targeted subsidies to purchase seeds and fertilizers for the next harvest.

\footnotetext{
${ }^{6}$ The projected reduction in the nonoil primary deficit, from 6.8 percent of nonoil GDP in 2008 to 4.3 percent in 2009 , stems mainly from the elimination of fuel subsidies.
} 
- Lower international oil prices offer an opportunity to eliminate fuel subsidies in 2009 and resume timely retail fuel price adjustments. In this regard, options for rolling out targeted mechanisms to protect the poor are under consideration.

- The decline in oil revenue is expected to turn the overall fiscal balance in 2009 into a deficit. While the country's low debt level would allow it to borrow without jeopardizing fiscal sustainability, access to concessional financing could be limited in the near future in light of the global downturn. In addition, the domestic debt market is not yet operational. Hence, the deficit would have to be financed by drawing on the government deposits at the BEAC.

- Given the downside risks, the authorities agreed in principle on the need to consider contingent measures, in case revenues are much lower than expected. In this regard, they agreed that such measures should be rapid to implement, yield quick results, imply limited economic distortions, and minimize adverse effects on the poor. These actions would aim at safeguarding government deposits and would probably imply cuts in nonpriority spending.

\section{Box 3. Views from the Private Sector}

Staff had a number of meetings with the private sector, including representatives of the aluminum, banking, cement, cotton, electricity, forestry, and oil industries.

Private sector representatives have expressed concerns about the severe impact of the global crisis. Lower external demand and prices are affecting a number of key sectors in Cameroon, some of which were already in difficulty. The cotton sector, for instance, had been suffering from a steep increase in the cost of inputs, especially fertilizers, and production was in sharp decline. Spillover effects were expected to be significant, especially in the transport sector with about half of its activities related to the seriously affected timber industry.

Social costs were seen as high. The forestry sector (10,000 jobs) has laid off about 20 percent of its employees and put another 15 percent on forced leave. The cotton sector (370,000 jobs) is under threat. If the crisis were to be protracted and no action taken to help sectors in distress, especially timber, it was feared that the financial crisis could degenerate into a social crisis.

There were calls for immediate action. The private sector called for immediate measures to alleviate the impact in the sectors most affected, through subsidies or tax deferrals. It was suggested that the government help laid-off workers find other jobs to reduce hardship. Private sector representatives also underscored the need for structural reforms to make the economy more resilient to shocks and improve competitiveness. They stressed the importance of improving transparency and governance, access to financing, and public infrastructure (especially roads, ports and energy). 
15. The medium-term fiscal strategy should continue to reflect the nonrenewable nature of oil revenues and the need to address obstacles to growth, while preserving debt sustainability. Cameroon should limit fiscal deficits while oil revenues are significant so that future generations are not faced with a renewed debt burden. Oil revenues and available prudent borrowing should be effectively used to finance growth-enhancing investments. This strategy is ensured by maintaining a moderately positive nonoil current balance and by avoiding sizable overall deficits for as long as oil revenues remain substantial. Finally, fluctuations in the nonoil primary balance should be contained to avoid destabilizing effects on the economy. The macroeconomic framework discussed with the authorities is in line with these principles.

\section{Within this framework, the authorities recognize that existing fiscal buffers are} limited and adjustment efforts needed over the medium term. In view of limited financing prospects at terms consistent with safeguarding sustainability, a balanced overall fiscal position would need to be gradually restored over the medium term, while continued support is provided to the economy. The policy discussions focused on a three-pronged strategy: (i) increase nonoil revenues, (ii) rationalize public spending to protect priority programs, and (iii) develop alternative sources of domestic financing.

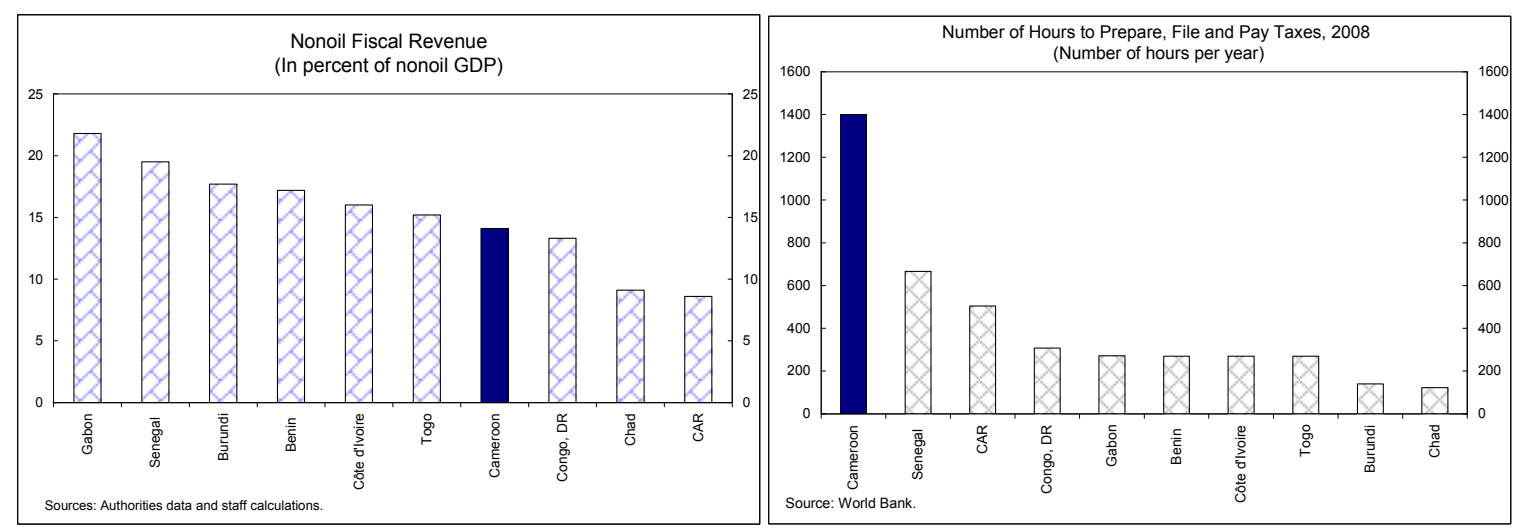

17. The recent significant decline in oil revenues makes it more urgent to continue efforts to mobilize additional nonoil revenues in order to protect priority spending. In view of the expected decline in oil production beyond 2012 and further envisaged import tariff reductions-and given that tax rates on capital income, labor, and consumption are already high-broadening the tax base through administrative measures is a key priority.

The authorities agreed that the priority should be to reduce the cost of compliance by simplifying tax procedures. In particular, the number of tax forms will be reduced. In addition, the opening of tax centers offering accounting and tax advice to small- and medium-sized enterprises is expected to facilitate compliance. 
Implementation of exemptions will be tightened. A more effective tracking system will be put in place to monitor transit trade and trading risk-profiles will be further developed to improve customs administration.

18. The quality of public spending would need to be improved. With tighter budgetary constraints, efforts to achieve greater efficiency should continue. In this regard, capital expenditure (and maintenance of existing infrastructure) would need to be stepped up to reduce the severe infrastructural bottlenecks, and provide a renewed and stronger impetus to growth. Related administrative capacity needs also to be further strengthened.

$>$ To be effective, new capital projects need to be carefully selected to maximize their impact on growth and integrated into a medium-term strategy. In this context, the authorities intend to continue (i) reinforcing public expenditure tracking and training of personnel; and (ii) building capacity to prepare, evaluate, and execute projects.

$>$ The large fluctuations in the treasury float make it difficult to assess the fiscal stance in any given period. In this regard, the authorities have committed to settle the arrears to SONARA in 2009 and produce comprehensive budgetary execution data on a payment orders basis by the end of the year.

$>$ The gradual implementation of the new public finance system law will require careful monitoring. Among the changes it introduces are a budget structured by program, stronger budget execution, more stringent accounting and control rules, and improved transparency. The introduction of such changes has been a challenge, even in advanced countries.

19. Alternative sources of financing should also be developed. A broader financing base could help protect priority spending while preserving fiscal sustainability and containing pressures on the region's pool of foreign exchange reserves. Staff recognized that the country's low debt level would allow it to borrow prudently without jeopardizing fiscal sustainability, and encouraged the authorities to continue to work with relevant regional agencies and take action to speed up the development of the domestic bond market.

\section{In this regard, the DSA analysis indicates that the risk of debt distress remains} low, but the authorities are taking steps to strengthen their debt management capacity. ${ }^{7}$ Cameroon's debt management was assessed by the World Bank as among the weakest in post-completion point HIPC countries. The authorities have indicated that improving this area is a priority. Following joint Bank-Fund technical assistance, they are working on implementing a new debt management strategy in line with CEMAC regional guidelines. This will require the definition of an institutional framework with clear responsibilities,

\footnotetext{
${ }^{7}$ Cameroon still has outstanding external arrears of about US $\$ 1.4$ million. The authorities have made every effort to finalize negotiations with the private creditors involved (see the attached Debt Sustainability Analysis). The lack of agreement with these creditors does not undermine Cameroon's reform and adjustment efforts.
} 
effective coordination of all relevant entities (Budget, Treasury, CAA, and BEAC), and the elaboration of an annual borrowing plan and calendar for the issuance of bonds suited for the country's financial situation.

\section{B. Raising Growth: Addressing the Bottlenecks}

21. The authorities recognize that an unfavorable investment climate is holding back the country's economic expansion. Inadequate infrastructure and an unfavorable business environment hamper output and export diversification and faster economic growth (Box 4). The authorities have initiated a dialogue with the private sector and donors to identify concrete measures and recognized that continued efforts to improve governance would reduce regulatory uncertainty.

\section{Further progress in reforming public enterprises would also help improve the} business environment. Progress in restructuring public enterprises and service delivery has been slow (Box 5). The authorities recognize that the global financial crisis could hamper access to financing and cause further delays for their privatization agenda. Against this, the opportunity should be taken to clarify the reform strategies, in particular for air transport and telecommunications, allowing a prompt finalization of the restructuring once international financial conditions improve.

23. Progress in trade liberalization would stimulate economic growth. The authorities signed an interim economic partnership agreement with the European Union (EU) in January 2009, pending a broader regional agreement with the other CEMAC members. Intra-CEMAC regional trade remains very limited, however. CEMAC import tariffs are among the highest in sub-Saharan Africa. ${ }^{8}$ Against this backdrop, the authorities agreed to continue to urge CEMAC partners to further liberalize trade by (i) reducing the maximum common external tariff (CET) from 30 to 20 percent, and (ii) harmonizing rules of origin and streamlining CET exemptions, and (iii) working toward a regional trade agreement with the EU.

\section{Assuring the Stability of the Financial System}

\section{Although the banking sector is generally sound, there are pockets of}

vulnerability. Observance of regional prudential norms has generally improved, but the compliance of some Cameroonian banks with capital requirements and credit exposure limits remains weak, making them vulnerable to an economic slowdown. In this regard, the authorities agreed that they would continue to work with the relevant regional agencies to monitor closely developments in the banking sector, and in particular ensure timely

\footnotetext{
${ }^{8}$ Major constraints on greater intraregional trade include weak regional infrastructure and lack of production diversification.
} 
assessment of asset quality and adequate provisioning for nonperforming loans, and enforce corrective action where needed.

\section{Box 4. Infrastructure Bottlenecks to Growth and Challenges Ahead}

Several factors have held back Cameroon's growth. Cameroon's productivity played a key role in boosting growth after the devaluation of the CFA franc in 1994. The impulse from the devaluation was accompanied by a number of structural reforms in the telecommunications, port, railroad, and banking sectors. Since then, productivity gains have slowed down and growth has been far slower than in other lower-middleincome countries. A shallower financial market, a lower investment rate, a generally unattractive business environment, and

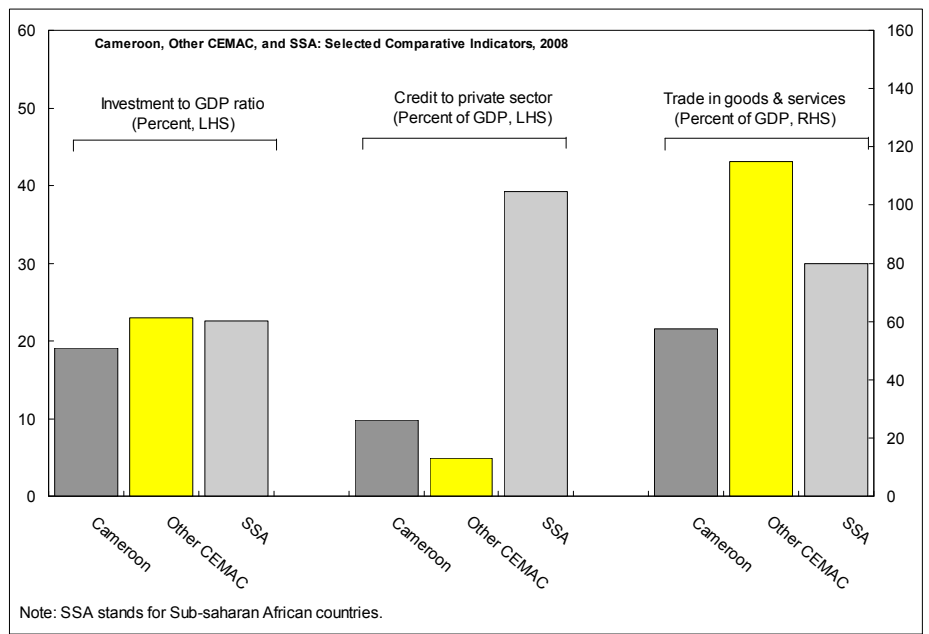
inadequate infrastructure have been mentioned as the main reasons. Improvements in these areas will be crucial to achieve faster growth.

Inadequate transport services and unreliable electricity supply are particularly problematic. Improving roads and access to market remains a major objective. Only about 8 percent of Cameroon's road network is paved, far below the lowermiddle-income-country average. Much of this network, including the paved areas, is of questionable quality and insufficient capacity. The rainy season severely compounds

\begin{tabular}{|lrr|}
\hline \multicolumn{2}{|c|}{ Cameroon: Bottlenecks to Growth, 2007 } \\
\hline & $\begin{array}{r}\text { Lower-Middle- } \\
\text { Income } \\
\text { Economies }\end{array}$ \\
\hline Physical infrastructure $^{1}$ & Cameroon & \\
Paved roads (percent of road network) $^{\mid}$ & 8.4 & 23.1 \\
Electric power (consumption per capita kWh) $^{2}$ & 186.0 & $1,380.0$ \\
Telephone subscribers $^{2}$ & $1,050.0$ & 566.0 \\
Households with television (percent) & 25.0 & 63.0 \\
\hline
\end{tabular}

Source: World Bank Development Indicators Database; and Cameroonian authorities.

${ }^{1}$ Data for 2000-06.

${ }^{2}$ Mobile cellular and fixed-line subscribers per employee, 2008. transportation problems. Surveys have highlighted that unreliable electricity supply was also a major deterrent for private investors. Electricity consumption in Cameroon is far lower than in other lower-middle-income countries. Supply is insufficient and distribution is uneven, with frequent blackouts affecting also important parts of the public administration. 


\section{Box 5. Public Enterprise Reform}

The authorities have been carrying out public enterprise restructuring programs to improve their performance and the quality of services they provide, as well as reduce the burden on the budget. Progress, however, has been slow, contributing to the infrastructure bottlenecks that hamper faster economic growth.

CAMAIR (the national airline company) ceased operations in May 2008 and is being liquidated. The authorities have stepped up their efforts to launch a successor company, CAMAIRCo. The preparatory work for issuing the bids for the selection of a strategic partner is ongoing, but the prospects are problematic in the current financial environment.

Bids for the privatization of CAMTEL (the telephone company) were issued in March 2007, but the government judged the offers unsatisfactory. It is now considering a management contract as a more appropriate framework, in light of the investment it has made to set up a fiber optic backbone and the significant market power it would convey to a private operator.

Efforts to reduce the costs of SONARA (the oil refinery) continue. The financing package for the expansion of its production capacity is being finalized and would allow greater economies of scale. The next step is to improve efficiency to allow the refinery to process more of the heavier Cameroonian crudes.

The 2008 financial accounts for CAMPOST (the postal bank) have been produced. A business plan has been prepared by the management company on how best to provide financial services to rural areas and move ahead with the restructuring. The authorities are examining the options.

\section{The authorities recognize that bank credit remains hampered by a poorly functional judicial system, absence of adequate collateral, and limited credit} information. Given the global financial crisis, credit conditions could become even tighter if impediments to access are not tackled and asset quality deteriorates. The authorities agreed, therefore, to accelerate the implementation of their action plan to deepen financial intermediation, based on the recommendations of the 2007 FSAP mission. The plan aims to (i) improve credit information by supporting the BEAC in finalizing implementation of the central credit registry; (ii) introduce financial instruments appropriate to small and medium enterprises such as factoring, leasing, and venture capital; and (iii) improve contract enforcement by setting up a court dedicated to commercial matters and facilitating out-of-court settlements. 


\section{ESF REQUEST}

\section{Cameroon is facing difficulties caused primarily by sudden and exogenous} shocks with a severe impact on the economy. Declining commodity prices, lower external demand, and tighter external financing are adversely affecting key economic activities. Growth projections have been revised downwards and the overall external balance is expected to turn into a deficit. A financing requirement of CFAF 111 billion (1.1 percent of GDP), which mirrors the fiscal gap, would emerge if the deterioration in the country's notional foreign exchange reserves were to be limited to a level corresponding to about 5 months of imports.

\section{The authorities have expressed concern about the size of the shocks and the pace} of deterioration of their fiscal buffers. The authorities consider it prudent to maintain government deposits at about their current level (equivalent to about 2.6 percent of GDP or $13 / 4$ months of public spending), given (i) the uncertain duration of the global crisis, (ii) the volatility of oil revenues, (iii) the risk of contingent liabilities materializing, considering the pockets of vulnerability in the banking system, (iv) the absence of an operational market for government securities, and (v) their commitment to regularizing their payment arrears. Under current conditions and without additional financing, the authorities' proposed fiscal strategy would imply, however, a decline in usable government deposits from 2.6 percent of GDP at end-2008 to about $1 \frac{1}{2}$ percent of GDP at end-2009 (equivalent to about a month of spending). ${ }^{9}$

\section{Against this background, the authorities have requested Fund financing under} the rapid-access component of the ESF in the amount of SDR 92.85 million (50 percent of quota). In light of the unfinished structural agenda, the authorities intend to move rapidly to a new PRGF arrangement and have approached other multilateral development partners for additional financing. Meanwhile, rapid Fund assistance would provide some temporary additional financial support to help the economy adjust to the exogenous shocks, and to ensure that priority outlays (investment, health, education) are protected in 2009.

\section{Cameroon has adequate capacity to repay the Fund (Table 6). Access of} 50 percent of quota (about 0.6 percent of GDP) will not jeopardize debt sustainability. The country has a low stock of external debt, and the debt sustainability analysis places Cameroon at a low risk of debt distress. Following the HIPC Initiative assistance and MDRI debt relief, Cameroon's stock of public debt fell to about 10 percent of GDP and external debt to about 6 percent of GDP at end-2008, while the NPV of external debt stood at 10.2 percent of exports.

\footnotetext{
${ }^{9}$ Usable government deposits exclude C2D funds, earmarked for specific projects financed by France. Data for the first quarter of 2009 are in line with the projected deterioration.
} 


\section{RISKS}

30. The economic outlook is nevertheless subject to significant downside risks. The main risks relate to a further worsening or longer duration of the global downturn and delays in implementing the proposed policies.

- A sharper or more protracted growth decline in the global economy could lower demand and prices for commodities, including oil, and remittances. ${ }^{10}$

- Tighter financial conditions could dry up further net private capital inflows and postpone large infrastructure projects with adverse effects on the country's prospects for growth and poverty reduction.

- Lack of improvements in mobilizing nonoil revenue and reducing nonpriority spending could put greater pressure on the government's deposits at the regional central bank.

- Delays in improving the investment climate could hamper the expected pickup in nonoil exports and net capital inflows, putting pressure on the regional pool of foreign exchange reserves.

\section{Staff APPRAisal}

31. The global economic crisis is affecting Cameroon severely. After last year's social tensions arising from high food and fuel prices, the global crisis this year is providing yet another set of challenges. Lower oil prices are reducing exports and fiscal revenues. Considerably weaker external demand is adversely affecting key exports. Tighter external financing conditions have delayed important investment projects. As a result, growth projections have been revised downward, and the overall fiscal and external balances are projected to turn into deficit. Without appropriate social safety nets in place, the social costs of the downturn could be severe.

\section{Recent economic achievements provide Cameroon with a relatively solid} foundation for weathering the impact of the global crisis. Prudent management of oil windfalls under the recently completed PRGF-supported program has allowed the authorities to accumulate government deposits at the BEAC and contribute to the regional pool of foreign exchange reserves. These savings now provide welcome fiscal and external buffers that can be prudently used to alleviate the impact of the crisis.

\footnotetext{
${ }^{10}$ For instance, should international oil prices be US\$10/barrel lower than currently projected, fiscal revenues would be lower by 0.9 percentage point of GDP.
} 
33. Economic growth has, however, been too slow to reduce poverty. While the exchange rate is broadly in line with fundamentals, nonprice factors continue to adversely affect Cameroon's competitiveness. Limited infrastructure and an unfavorable business environment hamper faster economic development. On the current trajectory, Cameroon is highly unlikely to meet the MDGs. Against this backdrop, staff commends the authorities' commitment to continue to preserve macroeconomic stability and tackle structural impediments to growth, although the global crisis will make this task more challenging.

34. The authorities have already taken steps to deal with the shocks. Staff agrees that the implementation of the 2009 budgetary priority spending plans should be maintained to avoid a public sector contraction in a year of declining economic growth. Targeted measures are being put in place to help particular sectors in difficulty and alleviate social distress.

\section{Staff welcomes the accelerated implementation of structural measures to} increase the economy's resilience to shocks. The authorities have committed to enhance their efforts to achieve greater nonoil revenue mobilization, strengthen public expenditure management and transparency, and develop alternative sources of financing. Decisive actions are also needed to improve governance, make the business environment more attractive, and enhance the still limited role of the financial sector in the development of the economy. Staff welcomes the authorities' efforts and commitment to address these challenges through a medium-term economic program in the context of a new PRS under preparation.

\section{Staff supports the authorities' request for the rapid-access component of the}

ESF. The authorities have demonstrated a readiness to collaborate with the Fund in finding solutions to the deteriorating balance of payments situation. Their policy commitments appropriately address the impact of the shocks and contribute to making the economy more resilient. Rapid Fund support would contribute to contain the decline in the country's notional foreign exchange reserves and in usable government deposits to a level that is prudent to maintain in light of the uncertainties facing the economy. Cameroon has adequate capacity to repay the Fund and, with a low risk of debt distress, access of 50 percent of quota will not jeopardize debt sustainability.

\section{Nonetheless, the authorities should continue to remain vigilant against the} possibility of downside risks. While not directly affected, the financial sector in particular could be negatively affected by a protracted economic slowdown and act as a further drag on growth if credit conditions become tighter. Developments in this sector should be closely monitored in cooperation with regional supervisors and corrective actions taken if needed.

\section{It is proposed that the next Article IV consultation with Cameroon take place on the standard 12-month cycle.}


Table 1. Cameroon: Selected Economic and Financial Indicators, 2007-12

\begin{tabular}{|c|c|c|c|c|c|c|}
\hline & 2007 & $\frac{2008}{\text { Est. }}$ & $\frac{2009}{\text { Proj. }}$ & $\frac{2010}{\text { Proj. }}$ & $\frac{2011}{\text { Proj. }}$ & $\frac{2012}{\text { Proj. }}$ \\
\hline & \multicolumn{6}{|c|}{ (Annual percentage changes, unless otherwise indicated) } \\
\hline \multicolumn{7}{|l|}{ National income and prices } \\
\hline GDP at constant prices & 3.5 & 3.4 & 2.4 & 2.6 & 4.0 & 4.2 \\
\hline Oil & -5.2 & -6.4 & -9.4 & -10.0 & 13.1 & 9.7 \\
\hline Nonoil & 4.1 & 4.1 & 3.1 & 3.3 & 3.6 & 3.9 \\
\hline GDP deflator & 2.1 & 1.5 & -3.3 & 2.4 & 2.0 & 2.0 \\
\hline Consumer prices (12-month average) & 1.1 & 5.3 & 2.7 & 2.0 & 2.0 & 2.0 \\
\hline Nominal GDP (CFA F billions) & 9,916 & 10,410 & 10,311 & 10,838 & 11,493 & 12,217 \\
\hline Oil & 948 & 1,161 & 718 & 754 & 896 & 1,009 \\
\hline Nonoil & 8,968 & 9,249 & 9,593 & 10,084 & 10,597 & 11,207 \\
\hline Oil output (thousands of barrels a day) & 86 & 84 & 78 & 70 & 79 & 87 \\
\hline \multicolumn{7}{|l|}{ External trade } \\
\hline Export volume & 2.3 & 0.7 & -4.6 & 0.8 & 7.7 & 5.7 \\
\hline Of which: nonoil sector & 4.1 & 1.7 & -4.1 & 4.0 & 6.2 & 4.5 \\
\hline Import volume & 23.1 & 8.7 & -8.1 & 4.1 & 5.3 & 6.0 \\
\hline Average oil export price (US\$ per barrel) & 69.6 & 94.3 & 57.5 & 71.5 & 75.0 & 77.0 \\
\hline Nominal effective exchange rate & 2.4 & 1.9 & $\ldots$ & $\ldots$ & $\ldots$ & $\ldots$ \\
\hline Real effective exchange rate & 1.2 & 3.3 & $\ldots$ & $\ldots$ & $\ldots$ & $\ldots$ \\
\hline Terms of trade & -1.6 & 8.7 & -20.9 & 12.5 & 4.4 & 2.3 \\
\hline Nonoil export price index (CFA F) & -3.3 & 2.7 & -8.2 & 3.5 & 3.4 & 2.9 \\
\hline \multicolumn{7}{|l|}{ Money and credit (end of period) } \\
\hline Net domestic assets ${ }^{7}$ & -9.2 & 1.8 & 14.6 & 8.3 & 10.3 & 8.0 \\
\hline Net credit to the public sector ${ }^{7}$ & -6.8 & -6.5 & 1.7 & 1.7 & 3.4 & 1.0 \\
\hline Credit to the private sector & 5.9 & 19.6 & 13.0 & 12.5 & 12.0 & 11.8 \\
\hline Broad money (M2) & 18.6 & 13.4 & 0.4 & 5.1 & 6.0 & 5.2 \\
\hline Velocity (GDP/average M2) & 5.3 & 5.0 & 5.0 & 5.0 & 5.0 & 5.0 \\
\hline \multicolumn{7}{|l|}{ Central government operations } \\
\hline Total revenue & 3.3 & 18.5 & -12.8 & 0.2 & 12.6 & 9.5 \\
\hline \multirow[t]{2}{*}{ Total expenditure } & 12.9 & 22.1 & -2.9 & 5.1 & 6.1 & 7.2 \\
\hline & \multicolumn{6}{|c|}{ (Percent of GDP, unless otherwise indicated) } \\
\hline Gross national savings & 17.4 & 18.0 & 12.1 & 14.0 & 15.5 & 16.9 \\
\hline Gross domestic investment & 18.2 & 19.1 & 18.0 & 18.3 & 19.1 & 20.2 \\
\hline Public investment & 3.9 & 5.7 & 5.8 & 6.0 & 6.3 & 6.6 \\
\hline Private investment & 14.3 & 13.4 & 12.2 & 12.3 & 12.8 & 13.6 \\
\hline \multicolumn{7}{|l|}{ Central government operations } \\
\hline Total revenue (excluding grants) & 18.8 & 20.4 & 18.1 & 17.3 & 18.4 & 18.9 \\
\hline Oil revenue & 6.4 & 7.8 & 4.9 & 4.0 & 4.9 & 5.3 \\
\hline Nonoil revenue (percent of nonoil GDP) & 13.8 & 14.2 & 14.2 & 14.3 & 14.6 & 14.8 \\
\hline Total expenditure & 15.5 & 19.9 & 18.7 & 18.7 & 18.7 & 18.8 \\
\hline \multicolumn{7}{|l|}{ Fiscal balance (including net changes in arrears) } \\
\hline Excluding grants & 2.5 & 1.1 & -1.8 & -1.6 & -0.5 & -0.1 \\
\hline Including grants & 3.7 & 2.0 & -0.8 & -0.7 & 0.2 & 0.4 \\
\hline Nonoil primary balance (percent of nonoil GDP) & -1.5 & -6.8 & -4.3 & -4.5 & -4.6 & -4.8 \\
\hline \multicolumn{7}{|l|}{ External sector } \\
\hline Current account balance (including grants) & -0.8 & -1.0 & -5.9 & -4.2 & -3.6 & -3.3 \\
\hline Gross official reserves ${ }^{2}$ & 4.8 & 6.2 & 4.9 & 4.2 & 3.5 & 3.0 \\
\hline Stock of external public debt & 5.5 & 5.5 & 7.5 & 8.0 & 8.3 & 8.6 \\
\hline \multirow[t]{2}{*}{ Stock of public debt } & 11.8 & 9.8 & 12.4 & 13.1 & 13.2 & 13.3 \\
\hline & \multicolumn{6}{|c|}{ (Percent of exports of goods and services, unless otherwise indicated) ${ }^{3}$} \\
\hline NPV of external debt & $\ldots$ & 10.2 & 21.3 & 22.7 & 21.9 & 22.2 \\
\hline External debt service & 0.8 & 0.7 & 1.5 & 1.1 & 1.3 & 1.3 \\
\hline External debt service (as a percent of government revenue) & 1.4 & 1.2 & 1.8 & 1.5 & 1.8 & 1.7 \\
\hline
\end{tabular}

Sources: Cameroonian authorities; and IMF staff estimates and projections.

${ }^{1}$ Percent of broad money at the beginning of the period.

${ }^{2}$ In months of next year's imports of goods and services.

${ }^{3}$ Estimations and calculations are based on the revised DSA (June 2009) using the LIC Debt Sustainability Framework methodology. 
Table 2. Cameroon: Balance of Payments, 2007-14

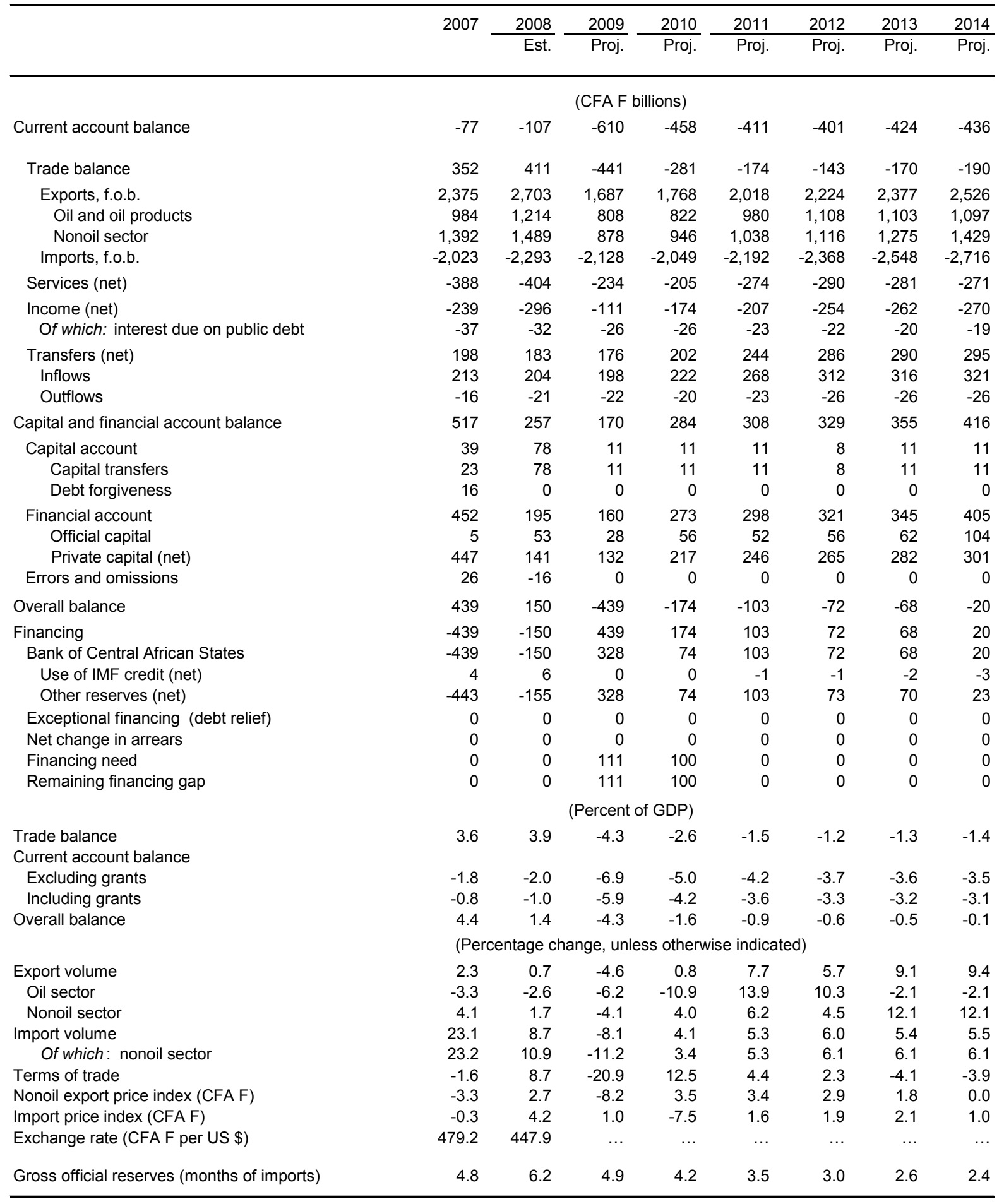

Sources: Cameroonian authorities; and IMF staff estimates and projections. 
Table 3. Cameroon: Monetary Survey, December 2005-December 2012 (CFA F billions, unless otherwise noted)

\begin{tabular}{|c|c|c|c|c|c|c|c|c|}
\hline & 2005 & 2006 & 2007 & $\begin{array}{r}2008 \\
\text { Dec. } \\
\text { Est. }\end{array}$ & $\begin{array}{c}2009 \\
\text { Dec. } \\
\text { Proj. }\end{array}$ & $\begin{array}{c}2010 \\
\text { Dec. } \\
\text { Proj. }\end{array}$ & $\begin{array}{l}2011 \\
\text { Dec. } \\
\text { Proj. }\end{array}$ & $\begin{array}{c}2012 \\
\text { Dec. } \\
\text { Proj. }\end{array}$ \\
\hline Net foreign assets & 500 & 1,034 & 1,510 & 1,745 & 1,417 & 1,343 & 1,240 & 1,168 \\
\hline Bank of Central African States (BEAC) & 382 & 856 & 1,296 & 1,445 & 1,112 & 1,038 & 936 & 864 \\
\hline Commercial banks & 118 & 178 & 220 & 304 & 304 & 304 & 304 & 304 \\
\hline Net domestic assets & 1,069 & 679 & 522 & 558 & 896 & 1,088 & 1,338 & 1,545 \\
\hline Domestic credit & 1,174 & 863 & 816 & 855 & 1,035 & 1,228 & 1,477 & 1,684 \\
\hline Net claims on the public sector & 338 & -2 & -119 & -250 & -212 & -173 & -90 & -65 \\
\hline Net credit to the central government & 238 & -90 & -222 & -378 & -368 & -368 & -368 & -407 \\
\hline Claims & 461 & 301 & 80 & 0 & 0 & 0 & 0 & 0 \\
\hline Deposits & -223 & -391 & -302 & -378 & -368 & -368 & -368 & -407 \\
\hline Of which: usable (excluding C2D) ${ }^{1}$ & -223 & -326 & -212 & -273 & -273 & -273 & -273 & -303 \\
\hline Credit to autonomous agencies & 22 & 17 & 17 & 14 & 14 & 16 & 20 & 23 \\
\hline Credit to public enterprises & 78 & 71 & 86 & 114 & 143 & 179 & 259 & 319 \\
\hline Credit to financial institutions & 4 & 6 & 25 & 17 & 17 & 17 & 17 & 17 \\
\hline Credit to the private sector & 832 & 859 & 910 & 1,088 & 1,230 & 1,383 & 1,549 & 1,732 \\
\hline Other items (net) & -106 & -184 & -294 & -297 & -140 & -140 & -140 & -140 \\
\hline Money and quasi-money & 1,568 & 1,713 & 2,032 & 2,303 & 2,312 & 2,431 & 2,578 & 2,713 \\
\hline Currency outside banks & 273 & 259 & 355 & 431 & 431 & 447 & 558 & 602 \\
\hline Deposits & 1,295 & 1,455 & 1,677 & 1,873 & 1,881 & 1,984 & 2,019 & 2,111 \\
\hline \multicolumn{9}{|l|}{ Memorandum items: } \\
\hline \multicolumn{9}{|c|}{ Contribution to the growth of broad money (percentage points) } \\
\hline Net foreign assets & 9.5 & 34.1 & 27.8 & 11.5 & -14.2 & -3.2 & -4.2 & -2.8 \\
\hline Net domestic assets & -5.3 & -24.8 & -9.2 & 1.8 & 14.6 & 8.3 & 10.3 & 8.0 \\
\hline Of which: credit to the central government & -9.0 & -20.9 & -7.7 & -7.7 & 0.4 & 0.0 & 0.0 & -1.5 \\
\hline Private sector credit (annual percentage change) & 10.9 & 3.2 & 5.9 & 19.6 & 13.0 & 12.5 & 12.0 & 11.8 \\
\hline Broad money (annual percentage change) & 4.2 & 9.3 & 18.6 & 13.4 & 0.4 & 5.1 & 6.0 & 5.2 \\
\hline Currency & -15.6 & -5.4 & 37.4 & 21.2 & 0.1 & 3.7 & 24.9 & 7.8 \\
\hline Deposits & 9.6 & 12.4 & 15.3 & 11.7 & 0.5 & 5.4 & 1.8 & 4.5 \\
\hline Velocity (GDP/average M2) & 5.9 & 5.8 & 5.3 & 5.0 & 5.0 & 5.0 & 5.0 & 5.0 \\
\hline
\end{tabular}

Sources: BEAC; and IMF staff estimates and projections.

${ }^{1}$ Earmarked for specific projects financed by France. 
Table 4. Cameroon: Central Government Operations; 2007-12 (CFA F billions)

\begin{tabular}{|c|c|c|c|c|c|c|}
\hline & \multirow[t]{2}{*}{2007} & 2008 & 2009 & 2010 & 2011 & 2012 \\
\hline & & Est. & Proj. & Proj. & Proj. & Proj. \\
\hline Total revenue and grants & 1,985 & 2,215 & 1,978 & 1,965 & 2,190 & 2,372 \\
\hline Total revenue & 1,867 & 2,122 & 1,870 & 1,874 & 2,109 & 2,309 \\
\hline Oil sector revenue & 631 & 810 & 504 & 429 & 566 & 648 \\
\hline Nonoil sector revenue & 1,236 & 1,312 & 1,366 & 1,444 & 1,543 & 1,661 \\
\hline Total grants & 118 & 92 & 108 & 91 & 81 & 63 \\
\hline Projects & 23 & 26 & 11 & 11 & 11 & 8 \\
\hline Programs & 0 & 0 & 5 & 0 & 0 & 0 \\
\hline Other & 95 & 66 & 93 & 81 & 70 & 55 \\
\hline Total expenditure & 1,542 & 2,068 & 1,925 & 2,023 & 2,146 & 2,301 \\
\hline Current expenditure & 1,151 & 1,497 & 1,338 & 1,376 & 1,423 & 1,490 \\
\hline Wages and salaries & 435 & 561 & 624 & 640 & 664 & 693 \\
\hline Goods and services & 436 & 512 & 491 & 504 & 521 & 548 \\
\hline Debt relief-financed & 17 & 27 & 55 & 38 & 31 & 29 \\
\hline Subsidies and transfers & 230 & 388 & 187 & 197 & 204 & 217 \\
\hline Of which: fuel subsidies & 16 & 166 & 0 & 0 & 0 & 0 \\
\hline Pensions & 84 & 94 & 100 & 105 & 111 & 118 \\
\hline Interest due & 50 & 36 & 36 & 36 & 34 & 33 \\
\hline External & 37 & 32 & 26 & 25 & 23 & 21 \\
\hline Domestic & 14 & 4 & 10 & 11 & 11 & 12 \\
\hline Capital expenditure & 389 & 589 & 587 & 647 & 724 & 810 \\
\hline Domestic investment & 280 & 410 & 453 & 520 & 608 & 714 \\
\hline Foreign-financed investment & 62 & 99 & 114 & 118 & 105 & 96 \\
\hline Rehabilitation and participation & 47 & 80 & 20 & 10 & 10 & 0 \\
\hline Net lending & 14 & -14 & 0 & 0 & 0 & 0 \\
\hline Unclassified expenditure & -12 & -4 & 0 & 0 & 0 & 0 \\
\hline Overall balance, excluding net change & & & & & & \\
\hline Excluding grants & 326 & 54 & -54 & -150 & -37 & 9 \\
\hline Including grants & 444 & 146 & 54 & -59 & 43 & 72 \\
\hline Net change in arrears & -78 & 65 & -132 & -20 & -20 & -20 \\
\hline External & 0 & 0 & 0 & 0 & 0 & 0 \\
\hline Domestic & -78 & 65 & -132 & -20 & -20 & -20 \\
\hline Overall balance, including net change & & & & & & \\
\hline Excluding grants & 248 & 119 & -186 & -170 & -57 & -11 \\
\hline Including grants & 366 & 211 & -78 & -79 & 23 & 52 \\
\hline Financing & -366 & -211 & -33 & -21 & -23 & -52 \\
\hline External financing, net & -47 & -7 & 16 & 43 & 38 & 42 \\
\hline Amortization & -87 & -80 & -87 & -64 & -56 & -46 \\
\hline Drawings & 40 & 73 & 103 & 107 & 95 & 88 \\
\hline Project financing & 40 & 73 & 103 & 107 & 95 & 88 \\
\hline Program financing (loans) & 0 & 0 & 0 & 0 & 0 & 0 \\
\hline Domestic financing, net & -318 & -204 & -49 & -65 & -62 & -94 \\
\hline Banking system & -217 & -155 & 10 & 0 & 0 & -39 \\
\hline Banking system, excluding C2D & -191 & -140 & 0 & 0 & 0 & -30 \\
\hline Amortization & -106 & -59 & -59 & -65 & -62 & -55 \\
\hline Nonbank financing & 4 & 10 & 0 & 0 & 0 & 0 \\
\hline Reserves & 0 & 0 & 0 & 0 & 0 & 0 \\
\hline Remaining financing needs & 0 & 0 & 111 & 100 & 0 & 0 \\
\hline Memorandum items: & & & & & & \\
\hline Nonoil primary balance & -137 & -628 & -415 & -452 & -488 & -543 \\
\hline Nonoil current balance & 202 & -75 & 137 & 160 & 201 & 234 \\
\hline
\end{tabular}

Sources: Cameroonian authorities; and IMF staff estimates and projections. 
Table 5. Cameroon: Selected Fiscal Indicators; 2007-12

(Percent of GDP, unless otherwise indicated)

\begin{tabular}{|c|c|c|c|c|c|c|}
\hline & \multirow[t]{2}{*}{2007} & 2008 & 2009 & 2010 & 2011 & 2012 \\
\hline & & Est & Proj. & Proj. & Proj. & Proj. \\
\hline Total revenue and grants & 20.0 & 21.3 & 19.2 & 18.1 & 19.1 & 19.4 \\
\hline Total revenue & 18.8 & 20.4 & 18.1 & 17.3 & 18.4 & 18.9 \\
\hline Oil sector revenue & 6.4 & 7.8 & 4.9 & 4.0 & 4.9 & 5.3 \\
\hline Nonoil sector revenue & 12.5 & 12.6 & 13.3 & 13.3 & 13.4 & 13.6 \\
\hline Total grants & 1.2 & 0.9 & 1.0 & 0.8 & 0.7 & 0.5 \\
\hline Total expenditure & 15.5 & 19.9 & 18.7 & 18.7 & 18.7 & 18.8 \\
\hline Current expenditure & 11.6 & 14.4 & 13.0 & 12.7 & 12.4 & 12.2 \\
\hline Wages and salaries & 4.4 & 5.4 & 6.1 & 5.9 & 5.8 & 5.7 \\
\hline Goods and services & 4.4 & 4.9 & 4.8 & 4.6 & 4.5 & 4.5 \\
\hline Debt relief-financed & 0.2 & 0.3 & 0.5 & 0.3 & 0.3 & 0.2 \\
\hline Subsidies and transfers & 2.3 & 3.7 & 1.8 & 1.8 & 1.8 & 1.8 \\
\hline Of which: fuel subsidies & 0.2 & 1.6 & 0.0 & 0.0 & 0.0 & 0.0 \\
\hline Pensions & 0.8 & 0.9 & 1.0 & 1.0 & 1.0 & 1.0 \\
\hline Interest due & 0.5 & 0.3 & 0.3 & 0.3 & 0.3 & 0.3 \\
\hline External & 0.4 & 0.3 & 0.2 & 0.2 & 0.2 & 0.2 \\
\hline Domestic & 0.1 & 0.0 & 0.1 & 0.1 & 0.1 & 0.1 \\
\hline Capital expenditure & 3.9 & 5.7 & 5.7 & 6.0 & 6.3 & 6.6 \\
\hline Domestic investment & 2.8 & 3.9 & 4.4 & 4.8 & 5.3 & 5.8 \\
\hline Foreign-financed investment & 0.6 & 1.0 & 1.1 & 1.1 & 0.9 & 0.8 \\
\hline Rehabilitation and participation & 0.5 & 0.8 & 0.2 & 0.1 & 0.1 & 0.0 \\
\hline Net lending & 0.1 & -0.1 & 0.0 & 0.0 & 0.0 & 0.0 \\
\hline Unclassified expenditure & -0.1 & 0.0 & 0.0 & 0.0 & 0.0 & 0.0 \\
\hline Overall balance, excluding net change & & & & & & \\
\hline Excluding grants & 3.3 & 0.5 & -0.5 & -1.4 & -0.3 & 0.1 \\
\hline Including grants & 4.5 & 1.4 & 0.5 & -0.5 & 0.4 & 0.6 \\
\hline Net change in arrears & -0.8 & 0.6 & -1.3 & -0.2 & -0.2 & -0.2 \\
\hline External & 0.0 & 0.0 & 0.0 & 0.0 & 0.0 & 0.0 \\
\hline Domestic & -0.8 & 0.6 & -1.3 & -0.2 & -0.2 & -0.2 \\
\hline Overall balance, including net change & & & & & & \\
\hline Excluding grants & 2.5 & 1.1 & -1.8 & -1.6 & -0.5 & -0.1 \\
\hline Including grants & 3.7 & 2.0 & -0.8 & -0.7 & 0.2 & 0.4 \\
\hline Financing & -3.7 & -2.0 & -0.3 & -0.2 & -0.2 & -0.4 \\
\hline External financing, net & -0.5 & -0.1 & 0.2 & 0.4 & 0.3 & 0.3 \\
\hline Amortization & -0.9 & -0.8 & -0.8 & -0.6 & -0.5 & -0.4 \\
\hline Drawings & 0.4 & 0.7 & 1.0 & 1.0 & 0.8 & 0.7 \\
\hline Project financing & 0.4 & 0.7 & 1.0 & 1.0 & 0.8 & 0.7 \\
\hline Program financing (loans) & 0.0 & 0.0 & 0.0 & 0.0 & 0.0 & 0.0 \\
\hline Domestic financing, net & -3.2 & -2.0 & -0.5 & -0.6 & -0.5 & -0.8 \\
\hline Banking system & -2.2 & -1.5 & 0.1 & 0.0 & 0.0 & -0.3 \\
\hline Banking system, excluding C2D & -1.9 & -1.3 & 0.0 & 0.0 & 0.0 & -0.2 \\
\hline Amortization & -1.1 & -0.6 & -0.6 & -0.6 & -0.5 & -0.5 \\
\hline Nonbank financing & 0.0 & 0.1 & 0.0 & 0.0 & 0.0 & 0.0 \\
\hline Reserves & 0.0 & 0.0 & 0.0 & 0.0 & 0.0 & 0.0 \\
\hline Remaining financing needs & 0.0 & 0.0 & 1.1 & 0.9 & 0.0 & 0.0 \\
\hline Memorandum items (percent of nonoi & & & & & & \\
\hline Nonoil revenue ${ }^{1}$ & 13.8 & 14.2 & 14.2 & 14.3 & 14.6 & 14.8 \\
\hline Nonoil primary balance & -1.5 & -6.8 & -4.3 & -4.5 & -4.6 & -4.8 \\
\hline Nonoil current balance & 2.2 & -0.8 & 1.4 & 1.6 & 1.9 & 2.1 \\
\hline
\end{tabular}

Sources: Cameroonian authorities; and IMF staff estimates and projections.

${ }^{1}$ Includes transparency effect from the new fuel price formula. Beginning in 2008, support provided to SONARA through lower taxation was replaced by an explicit subsidy, with an equivalent increase in nonoil revenue. This transparency effect amounts to 0.5 percent of GDP. 
Table 6. Cameroon: Indicators of Capacity to Repay the Fund, 2008-18

\begin{tabular}{|c|c|c|c|c|c|c|c|c|c|c|c|}
\hline & 2008 & 2009 & 2010 & 2011 & 2012 & 2013 & 2014 & 2015 & 2016 & 2017 & 2018 \\
\hline & Est. & \multicolumn{10}{|c|}{ Projections } \\
\hline \multicolumn{12}{|c|}{ Fund obligations based on existing credit (SDR millions) } \\
\hline Principal & - & - & - & 0.8 & 1.6 & 2.4 & 3.5 & 3.7 & 2.9 & 2.1 & 1.3 \\
\hline Charges and interest & 0.7 & 0.2 & 0.2 & 0.2 & 0.2 & 0.2 & 0.2 & 0.1 & 0.1 & 0.1 & 0.1 \\
\hline \multicolumn{12}{|c|}{ Fund obligations based on existing and prospective credit (In millions of SDRs) } \\
\hline Principal & - & - & - & 0.8 & 1.6 & 2.4 & 12.7 & 22.3 & 21.5 & 20.7 & 19.9 \\
\hline Charges and interest & 0.7 & 0.5 & 0.7 & 0.7 & 0.6 & 0.6 & 0.6 & 0.5 & 0.4 & 0.3 & 0.2 \\
\hline \multicolumn{12}{|c|}{ Total obligations based on existing and prospective credit } \\
\hline SDR millions & 0.7 & 0.5 & 0.7 & 1.5 & 2.2 & 3.0 & 13.3 & 22.8 & 21.9 & 21.0 & 20.1 \\
\hline CFA F billions & 0.5 & 0.4 & 0.5 & 1.1 & 1.6 & 2.2 & 9.7 & 16.6 & 15.9 & 15.2 & 14.6 \\
\hline Prcent of government revenue & 0.0 & 0.0 & 0.0 & 0.0 & 0.1 & 0.1 & 0.4 & 0.6 & 0.5 & 0.5 & 0.4 \\
\hline Percent of exports of goods and services & 0.0 & 0.0 & 0.0 & 0.0 & 0.1 & 0.1 & 0.3 & 0.4 & 0.4 & 0.4 & 0.3 \\
\hline Percent of debt service ${ }^{2}$ & 0.5 & 0.3 & 0.5 & 1.3 & 2.4 & 3.4 & 15.4 & 28.5 & 29.9 & 30.1 & 33.5 \\
\hline Percent of GDP & 0.0 & 0.0 & 0.0 & 0.0 & 0.0 & 0.0 & 0.1 & 0.1 & 0.1 & 0.1 & 0.1 \\
\hline Percent of quota & 0.4 & 0.3 & 0.4 & 0.8 & 1.2 & 1.6 & 7.2 & 12.3 & 11.8 & 11.3 & 10.8 \\
\hline \multicolumn{12}{|l|}{ Outstanding Fund credit } \\
\hline SDR millions & 18.6 & 111.4 & 111.4 & 110.6 & 109.0 & 106.7 & 93.9 & 71.6 & 50.2 & 29.5 & 9.6 \\
\hline CFA F billions & 13.2 & 83.7 & 81.0 & 80.1 & 78.9 & 77.4 & 68.2 & 52.0 & 36.4 & 21.4 & 6.9 \\
\hline Percent of government revenue & 0.6 & 4.5 & 4.3 & 3.8 & 3.4 & 3.2 & 2.6 & 1.9 & 1.2 & 0.7 & 0.2 \\
\hline Percent of exports of goods and services & 0.4 & 3.6 & 3.3 & 2.9 & 2.6 & 2.4 & 1.9 & 1.4 & 0.9 & 0.5 & 0.2 \\
\hline Percent of debt service & 11.8 & 74.2 & 91.0 & 101.2 & 117.2 & 118.7 & 108.4 & 89.6 & 68.5 & 42.2 & 15.9 \\
\hline Percent of GDP & 0.1 & 0.8 & 0.7 & 0.7 & 0.6 & 0.6 & 0.5 & 0.3 & 0.2 & 0.1 & 0.0 \\
\hline Percent of quota & 10.0 & 60.0 & 60.0 & 59.6 & 58.7 & 57.4 & 50.6 & 38.6 & 27.0 & 15.9 & 5.1 \\
\hline Net use of Fund credit (SDR millions) & 5.3 & 95.5 & - & -0.8 & -1.6 & -2.4 & -12.7 & -22.3 & -21.5 & -20.7 & -19.9 \\
\hline Disbursements & 5.3 & 95.5 & - & - & - & - & - & - & - & - & - \\
\hline Repayments and repurchases & & - & - & 0.8 & 1.6 & 2.4 & 12.7 & 22.3 & 21.5 & 20.7 & 19.9 \\
\hline \multicolumn{12}{|l|}{ Memorandum items: (CFA F billions) } \\
\hline Nominal GDP & 10,410 & 10,311 & 10,838 & 11,493 & 12,217 & 13,034 & 14,004 & 15,141 & 16,498 & 17,909 & 19,368 \\
\hline Exports of goods and services & 3,645 & 2,341 & 2,463 & 2,785 & 3,053 & 3,289 & 3,521 & 3,758 & 3,909 & 4,185 & 4,478 \\
\hline Government revenue & 2,122 & 1,870 & 1,874 & 2,109 & 2,309 & 2,432 & 2,586 & 2,778 & 2,917 & 3,130 & 3,342 \\
\hline Debt service $^{2}$ & 111.7 & 112.7 & 89.0 & 79.2 & 67.3 & $\begin{array}{r}2,402 \\
65.2\end{array}$ & $\begin{array}{r}62.9 \\
62.9\end{array}$ & 58.1 & 53.2 & 50.7 & $\begin{array}{r}4,042 \\
43.6\end{array}$ \\
\hline
\end{tabular}

Sources: IMF staff estimates and projections.

${ }^{1}$ Includes disbursement (SDR 92.85 millions) under the ESF-RAC as of July 16, 2009

${ }^{2}$ Total debt service includes IMF repurchases and repayments. 


\section{APPENDIX-LETTER OF INTENT}

June 18,2009

Mr. Dominique Strauss-Kahn

Managing Director

International Monetary Fund

$70019^{\text {th }}$ Street, N.W.

Washington, D.C. 20431

U.S.A.

Dear Mr. Strauss-Kahn:

1. The conclusions of the Article IV consultation mission to Cameroon indicated that our country's economic situation, which had improved significantly with the implementation of reforms supported by the most recent PRGF arrangement (October 2005-January 2009), will deteriorate owing to the international economic crisis.

2. The Cameroonian economy remains vulnerable to fluctuations in global demand and commodity prices. In particular, the sharp decline in oil revenues this year will lead to a deterioration in the fiscal and external balances. These tighter financial conditions will make the government's efforts to accelerate economic growth, particularly through public investment, more challenging. Despite the progress made to consolidate macroeconomic stability, poor infrastructure and an unfavorable business environment still hamper economic activity and make it difficult to reach the growth rates needed to reduce poverty on a sustainable basis.

\section{Impact of the Shocks}

3. The global slowdown is having a severe impact on the Cameroonian economy through several channels:

- Lower international oil prices, which will lead to a significant deterioration in the terms of trade, as well as a substantial drop in fiscal oil revenues;

- Weaker external demand for our main export products, particularly timber, cotton, rubber, and aluminum;

- $\quad$ Tighter international financial conditions, which could delay some of our large mining and infrastructure projects;

- $\quad$ Reduced transfers from Cameroonians working abroad. 
4. This situation will negatively affect our net external balance and our economic growth, which could decline from $3 \frac{1}{2}$ percent in 2008 to $2 \frac{1}{2}$ percent in 2009 . The overall fiscal balance could also turn into a deficit of about 1 percent of GDP in 2009, while the balance of payments deficit could stand at around $4 \frac{1}{2}$ percent of GDP. The government is concerned by the magnitude of this deterioration (several percentage points of GDP).

\section{Policies to Address the Shocks}

5. To deal with this situation, the government has taken the immediate decision to maintain the priority expenditures included in the 2009 budget. It intends to use the available fiscal space to protect the economy from the effects of the global crisis and continue to lift the infrastructure bottlenecks hampering economic development. The government has also reaffirmed its commitment to eliminating subsidies on fuel prices and resuming implementation of the mechanism for adjusting the retail prices of petroleum products. To protect the most vulnerable segments of the population, it will continue its efforts to strengthen the social safety net, and look at the modalities and mechanisms for introducing a more targeted system.

6. The government has also taken measures to provide assistance to sectors in distress, particularly with a view to help small producers. In the timber sector, it has eliminated the bank guarantee required from taxpayers at the beginning of each fiscal year. It has also eliminated the factory admission tax for products entering second and third processing, thus reducing the cascading tax distortions adversely affecting the sector. It is also planning to reduce the annual timber royalty by half this year to take into account the decline in demand and lower prices for forestry products. In the cotton sector, the outstanding VAT credits have been cleared. Given the tight financial situation for small producers, there is a risk that many of them will lose their source of revenue this year if they are not able to produce. In this regard, discussions are ongoing with operators in the agricultural sector on the possibility of subsidizing inputs.

7. In this context, the government is committed to contain the overall fiscal deficit in 2009 to about 1 percent of GDP and the nonoil primary deficit to about 4 percent of GDP. For this purpose, it will adopt a supplementary budget in 2009 to reflect the decline in oil and nonoil revenues. On the expenditure side, the supplementary budget will take account of the need to maintain the initially planned priority expenditures, support the sectors in crisis, and eliminate arrears in the payments to SONARA to cover its losses incurred in 2008 as the result of the government's policy on retail prices for petroleum products.

8. The government also undertakes to respond to the exogenous shocks by implementing economic policies aimed at reducing the vulnerability of the Cameroonian economy while maintaining macroeconomic stability. To that end, it will take steps to: (i) increase nonoil revenues; (ii) diversify the sources of public financing; (iii) strengthen public expenditure management; (iv) improve the business environment; and (v) preserve the 
stability of the financial sector. In addition, the government will avoid introducing or intensifying trade restrictions.

\section{Increasing nonoil revenues}

9. The government will step up its efforts to mobilize nonoil revenues by expanding the tax base. To that end, the following measures will be implemented:

In regard to internal revenue:

$\underline{\text { In } 2009}$

- $\quad$ Simplify tax payment and filing procedures by cutting the number of forms to be filed by half, and hence reducing the high cost of tax compliance;

- $\quad$ Bring back into the general tax regime 19 enterprises identified as still benefiting unduly from exemptions;

- $\quad$ Establish management centers (offering tax and accounting services to small and medium-sized enterprises) to encourage operators in the informal sector to register with the tax administration, and improve and simplify the tax returns of operators already registered;

- $\quad$ Finalize the computer connection between the Ministry of Finance and the Ministry of Forestry and Wildlife to improve the exchange of information on taxpayers.

\section{$\underline{\text { In } 2010}$}

- $\quad$ Complete the work to update the fiscal cadastre in order to expand the property tax base;

- Implement electronic filing to continue to reduce the cost of tax compliance.

In regard to customs revenue:

$\underline{\text { In } 2009}$

- Improve the use of ASYCUDA (computerized customs system) through better tracking of its risk indicators to combat customs fraud;

- Introduce and use a GPS-based tracking mechanism to improve the monitoring of merchandise in transit and combat fraud affecting customs revenues;

- Accelerate implementation of the import duty sticker for tobacco and alcohol to combat smuggling and increase customs revenues. 
$\underline{\text { In } 2010}$

- Install ASYCUDA at other major revenue-collection posts, in particular Maroua and Garoua-Boulai, and establish computer connections between existing posts where ASYCUDA is installed;

- $\quad$ Computerize procedures and enhance data sharing by improving the electronic one-stop shop;

- Introduce a value registry to ensure proper application of the transaction value and achieve a better assessment of declared values.

\section{Diversification of the sources of public financing}

10. To diversify the sources of financing for the economy, the government plans to issue bonds in the coming year, as soon as the subregional mechanism is operational.

\section{Improvement of public expenditure management}

11. The government will continue its efforts to improve the quality of public spending to better match committed expenditures to services provided, and achieve savings that can be reallocated to priority outlays. To that end, starting in 2009 it will undertake a quarterly revision of the reference prices for government orders to limit overcharging and ensure the effectiveness of public spending.

12. Increasing public investment will be an essential component of our policy to foster economic recovery. The government undertakes to continue to: (i) improve the tracking of government spending; and (ii) strengthen capacity to prepare, evaluate, and implement projects. To that end, a consulting unit with government participation will be created in 2010 to build capacities for evaluating projects and ensuring that projects included in the government budget are carried through to completion.

13. The government will also take measures to improve fiscal transparency. The government intends to continue to publish quarterly reports on budget execution. The presentation of government financial operations (TOFE) on a payment order basis will be finalized in 2009 and will thereafter be produced on a regular basis to give a more complete picture of the government's fiscal commitments. In addition, the government recognizes the need to avoid excessive accumulation of arrears and treasury float. To that end, it will settle amounts remaining due to SONARA in 2009 and will continue its efforts to strengthen expenditure management.

14. A number of steps currently under way for the gradual implementation of the new public finance system law will be completed in 2009, in particular: (i) the drafting of the decree regulating government accounting, clarifying the fiscal operations of the government, 
the parties concerned, and their respective roles in the new environment; and (ii) the drafting of the methodological guide on the preparation of program budgets.

\section{Improvement of the business environment}

15. The authorities will give priority to development of the private sector in order to expand and diversify the production base and thus help to reduce the vulnerability of the economy to exogenous shocks. Emphasis will be placed on improving the business environment and combating corruption. To that end, the government is taking steps to create a more favorable environment for foreign investment with the help of the IFC. In 2009, planned priority actions focus on the simplification of procedures for establishing companies and improvement of cross-border trade.

\section{Protection of the stability of the financial sector}

16. Although contagion from the international financial crisis via financial channels seems very unlikely in Cameroon, a lasting slowdown in economic activity could increase the vulnerability of banks. To that end, the government will continue to work with the relevant regional authorities to strengthen surveillance of the banking system and limit any potential cost for the budget, while ensuring in particular that banks provision appropriately against nonperforming loans and that the needed corrective measures are taken.

\section{Request for Fund Assistance under the Rapid-Access Component of the ESF}

17. Despite these measures, the effects of the international crisis will result in an increased need for budget financing. In the absence of an operational government bond market, the overall fiscal deficit expected in 2009 could be financed by drawing on government deposits at the BEAC.

18. However, the current level of these deposits is appropriate to provide some guarantee in the face of: (i) uncertainties regarding the length of the international crisis; (ii) oil price volatility; (iii) the vulnerabilities of the banking sector; and (iv) the lack of a government bond market. To protect priority spending and not jeopardize poverty reduction efforts, it will be necessary to access other sources of financing.

19. Given the scope of these financing needs, the government has initiated discussions with its development partners to seek their assistance. Moreover, it is anticipated that the new Poverty Reduction Strategy Paper (PRSP) will be completed in August 2009 at the latest. This will be an important milestone for our dialogue with our partners and will lay the foundation for discussions with the IMF on a new program supported by the PRGF by end-2009. 
20. However, the mobilization of this financing will take time. We request, therefore, that the IMF allow the government of Cameroon the maximum access of 50 percent of quota (SDR 92.85 million) through the rapid-access component of the Exogenous Shocks Facility (ESF).

21. The government of Cameroon authorizes the IMF to publish this letter.

Sincerely yours,

$/ \mathrm{s} /$

Inoni Ephraim

Prime Minister and

Head of Government 


\title{
INTERNATIONAL MONETARY FUND AND \\ INTERNATIONAL DEVELOPMENT ASSOCIATION
}

\author{
CAMEROON
}

Joint Fund-Bank Debt Sustainability Analysis ${ }^{1}$

Prepared by the Staffs of the International Monetary Fund and the International Development Association

Approved by Mark Plant and Dhaneshwar Ghura (IMF) and Carlos Braga and Sudhir Shetty (World Bank)

June 19, 2009

The joint IMF-World Bank low-income country debt sustainability analysis (LIC DSA) indicates that Cameroon's risk of debt distress remains classified as low. All external debt ratios remain well below the policy-dependent thresholds under the baseline scenario and the stress tests; public debt indicators also remain at comfortable levels. Strengthening debt management practices, enhancing nonoil revenue mobilization, and widening the export base remains advisable in light of the anticipated long-run decline of oil revenues.

\footnotetext{
${ }^{1}$ Prepared by IMF and IDA staffs in collaboration with the Cameroonian authorities. The preliminary results were presented by IMF staff during a seminar organized by the Cameroonian authorities in Yaoundé on April 2, 2009. This DSA reflects comments from government officials and follows the IMF and World Bank Staff Guidance Note on the Application of the Joint Fund-Bank Debt Sustainability Framework for Low-Income Countries, October 9, 2008 (available at http://www.imf.org/external/pp/longres.aspx? id=4297 and http://go.worldbank.org/JBKAT4BH40). The analysis updates the 2008 DSA (IMF Country Report for Cameroon 08/279, available at http://www.imf.org/external/pubs/cat/longres.cfm?sk=22260.0 ). This DSA is conservatively undertaken on gross (as opposed to net) basis as no data on Cameroon's claim are available.
} 


\section{BACKGROUND}

1. This report updates the debt sustainability analysis (DSA) prepared in $\mathbf{2 0 0 8}$ (IMF Country Report No. 08/279). The baseline scenario reflects the latest IMF Article IV discussions with the authorities (March-April 2009). Since the 2008 DSA, Cameroon has been adversely affected by the global crisis through lower world demand and a drop in prices for commodities. Reduced export for timber, rubber, cotton, and aluminum products and lower oil production and prices have adversely affected GDP growth, with a sizable effect on both, the balance of payments and the fiscal accounts. As a result, the Cameroonian authorities have requested Fund assistance under the Rapid Access Component of the Exogenous Shocks Facility (ESF-RAC) in an amount equivalent to 50 percent of quota (0.6 percent of GDP). This DSA reflects these developments.

\section{The DSA is based on data provided by Cameroon's main multilateral creditors} and by the authorities on the remaining creditors. The debt data coverage continues to improve. It currently covers central government external debt, public-guaranteed debt, and an annual estimate of domestic debt. Despite efforts to improve debt statistics, the coverage of public enterprises' liabilities, contingent liabilities of financial institutions, and overdue claims of public enterprise and parastatal entities of the government remain uneven.

\section{Debt relief agreements with bilateral and most commercial creditors have been}

finalized. To date, all bilateral agreements with Paris Club and non-Paris Club creditors have been signed. Agreements were also finalized with most London Club commercial creditors, whereby the stock of debt was reduced to US\$1.4 million in 2008 compared to US\$91.2 million in 2007. Agreements have yet to be finalized with one bank (US\$0.5 million) and three nonbank corporations (US\$0.9 million). The authorities are making every effort to settle the outstanding debt ( 0.06 percent of GDP), but are experiencing difficulties in engaging with some creditors either because of a lack of response from them, or because they no longer exist as ongoing commercial entities.

4. Cameroon's debt situation has sharply improved in recent years. Its public debtto-GDP ratio declined from 51.8 percent in 2005 to 9.8 percent in 2008 (US $\$ 2.28$ billion), thanks to HIPC and MDRI relief in 2006 and prudent borrowing policies since then (Text Table 1). ${ }^{2}$ Since the HIPC Initiative and MDRI debt relief, further decline in external debt has reflected the following: (i) a reduction in net borrowing by public enterprises; (ii) the settlement of most London Club commercial creditors; and (iii) valuation effects due to

\footnotetext{
${ }^{2}$ Debt data, after the HIPC and MDRI, exclude the debt service to France under the Debt Settlement and Development Contract (C2D).
} 
changes in the exchange rate. On domestic debt, substantial repayments were also made possible due to the use of windfall gains from higher-than-expected oil prices in $2008 .^{3}$

Text Table 1. Cameroon: Stock of Public Debt, 2007-08

\begin{tabular}{lrrrrrrrr}
\hline & \multicolumn{2}{c}{ Million of US \$ } & & \multicolumn{2}{c}{ Percent of total } & & \multicolumn{2}{c}{ Percent of GDP } \\
\cline { 2 - 3 } & 2007 & 2008 & & 2007 & 2008 & & 2007 & 2008 \\
\hline Total & $2,450.2$ & $2,281.4$ & & 100.0 & 100.0 & & 11.8 & 9.8 \\
External & $1,173.6$ & $1,290.0$ & & 47.9 & 56.5 & 5.7 & 5.6 \\
Domestic & $1,276.6$ & 991.4 & & 52.1 & 43.5 & & 6.2 & 4.3
\end{tabular}

Sources: Cameroonian authorities; and Bank-Fund staff estimates.

Figure 1. Cameroon: Public- and Publicly-Guaranteed Debt Structure, End-2008

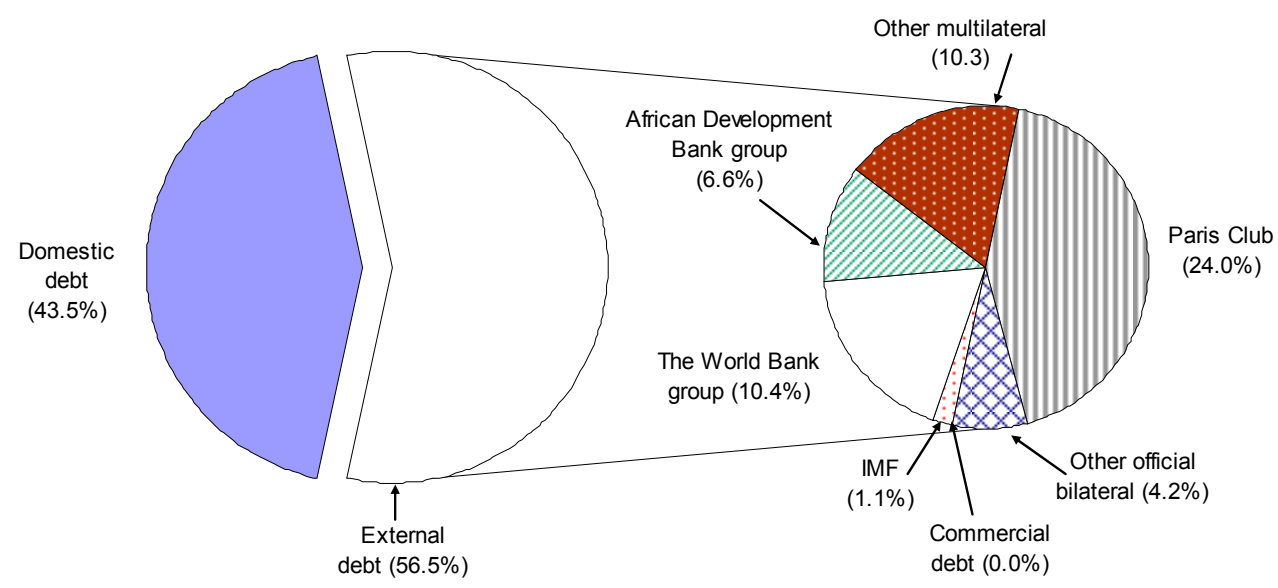

Sources: Cameroonian authorities; and Bank-Fund staff estimates.

${ }^{3}$ Domestic debt represents pre-end 2004 domestic arrears that were audited and rescheduled in 2005. 
5. The composition of external public debt is currently skewed toward bilateral debt. Following HIPC and MDRI debt relief in 2006, the share of bilateral debt increased to 52 percent in 2008 from 47 percent in 2005. As a result, between 2006 and 2008, the concessionality has been slightly lowered (from 41 percent to 39 percent), and the average interest rate has increased (from 1.1 percent to 1.4 percent).

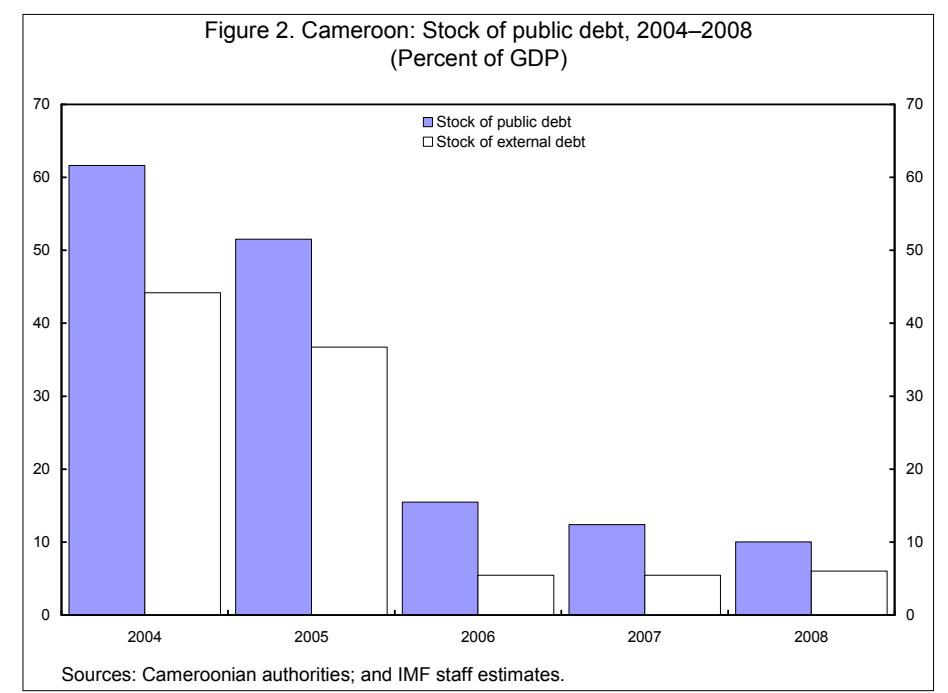

\section{The DSA BaSEline Scenario}

6. The medium- and long-term macroeconomic framework remains broadly unchanged relative to the previous DSA:

$>$ The international financial crisis and global slowdown affected adversely several macroeconomic variables, reflecting lower global demand and prices for key exports.

\section{$>$ However, the medium- and long-} term macroeconomic framework remains broadly unchanged relative to the previous DSA. More specifically, real GDP growth is expected to pick up over the medium term, reflecting increased investment and structural reform implementation. The current account deficit is

\begin{tabular}{|c|c|c|}
\hline \multicolumn{3}{|c|}{$\begin{array}{c}\text { Text Table 2. Cameroon: Key Macroeconomic } \\
\text { Assumptions, 2009-29 (updated vs. previous DSA) }{ }^{1}\end{array}$} \\
\hline & $2009-10$ & $2011-29$ \\
\hline \multicolumn{3}{|c|}{ Real GDP growth (percent) } \\
\hline Updated & 2.5 & 5.0 \\
\hline Previous & 4.7 & 5.3 \\
\hline \multicolumn{3}{|c|}{ Fiscal revenue (percent of GDP) } \\
\hline Updated & 18.7 & 17.6 \\
\hline Previous & 22.0 & 18.5 \\
\hline \multicolumn{3}{|c|}{ Exports (percent of GDP) } \\
\hline Updated & 22.7 & 23.6 \\
\hline Previous & 26.2 & 16.1 \\
\hline \multicolumn{3}{|c|}{ Oil price (U.S. dollars per barrel) } \\
\hline Updated & 64.5 & 70.1 \\
\hline Previous & 105.1 & 102.5 \\
\hline \multicolumn{3}{|c|}{$\begin{array}{l}\text { Sources: Cameroonian authorities; and } \\
\text { IMF and World Bank staffs estimates. } \\
{ }^{1} \text { Previous DSA covers the period 2008-28. }\end{array}$} \\
\hline
\end{tabular}
projected to deteriorate over the medium term, but then gradually improve over the longer term. Fiscal policy would be supportive of economic growth and poverty reduction. Over the medium term the nonoil primary balance is expected to deteriorate, reflecting the need to address considerable social and infrastructure needs. New public borrowing is assumed to increase gradually over the medium term to help finance infrastructure investments. 


\section{Box 1. Macroeconomic Assumptions for the Baseline Scenario ${ }^{4}$}

Against the backdrop of steady decline in oil production, the baseline annual growth, which is expected to be driven by the nonoil sector, has been revised downward in 2009-10 to about $2 \frac{1}{2}$ percent (3.2 percent for the nonoil sector growth), and is expected to increase gradually to 4.2 percent by 2012 on assumptions of increased capital spending and structural reforms in the areas of business climate, provision of public goods and infrastructure, and more efficient public finance management. Longer-term growth is expected to average 5.2 percent for 2015-29, driven by the nonoil sectors (agriculture, mining, and service). Staff projections include several distinct growth episodes. After an initial period of low growth in 2009-10 due to the financial crisis impact on Cameroon, growth is expected to pick up to about 4 percent in 2011-12. Growth is then projected to accelerate further to $5 \frac{1}{2}$ to 6 percent in 2013-16 reflecting the impact of envisaged structural reforms over the next 2-3 years aimed at improving transparency, governance, access to financing and a more competitive business environment, as well as new investment in public infrastructure, especially in transportation (including ports) and energy sectors. After 2016, growth would decline gradually to a more moderate range of 4 to $4 \frac{1}{2}$ percent, reflecting declining oil production and the weakening growth impact of the initial round of structural reform and investments projected to take place during 2010-13. Domestic investments over the projection period are expected to be sustained by capital inflows.

With the 2008 food and fuel crisis gradually abating, the consumer price-based inflation is expected to ease in 2009 and hold steady at around 2 percent — assuming a slow adjustment from the 2008 peak of over 5 percent but below the CEMAC threshold-over the medium- and long-term, in line with recent historical trend, which is also consistent with the CEMAC convergence criteria.

Government revenues are projected to decline over time as a result of reduced oil proceeds. Non-oil revenues are expected to rise from about 12/ $\frac{1}{2}$ percent of GDP in 2008 to about 16 percent at the end of the projection period, reflecting sustained implementation of measures to strengthen tax and customs administrations. Government expenditures are expected to rise over the medium term to about 19 percent of GDP. This path is consistent with a gradual increase in capital expenditure over the medium term, control of current spending growth, and a rise in pro-poor spending. The latter is also assumed to be achieved by improvements in public financial management, including expenditure allocation in priority areas.

\footnotetext{
${ }^{4}$ Estimates and projections are in CFA francs unless otherwise indicated. The baseline is consistent with the latest IMF World Economic Outlook assumptions and projections.
} 


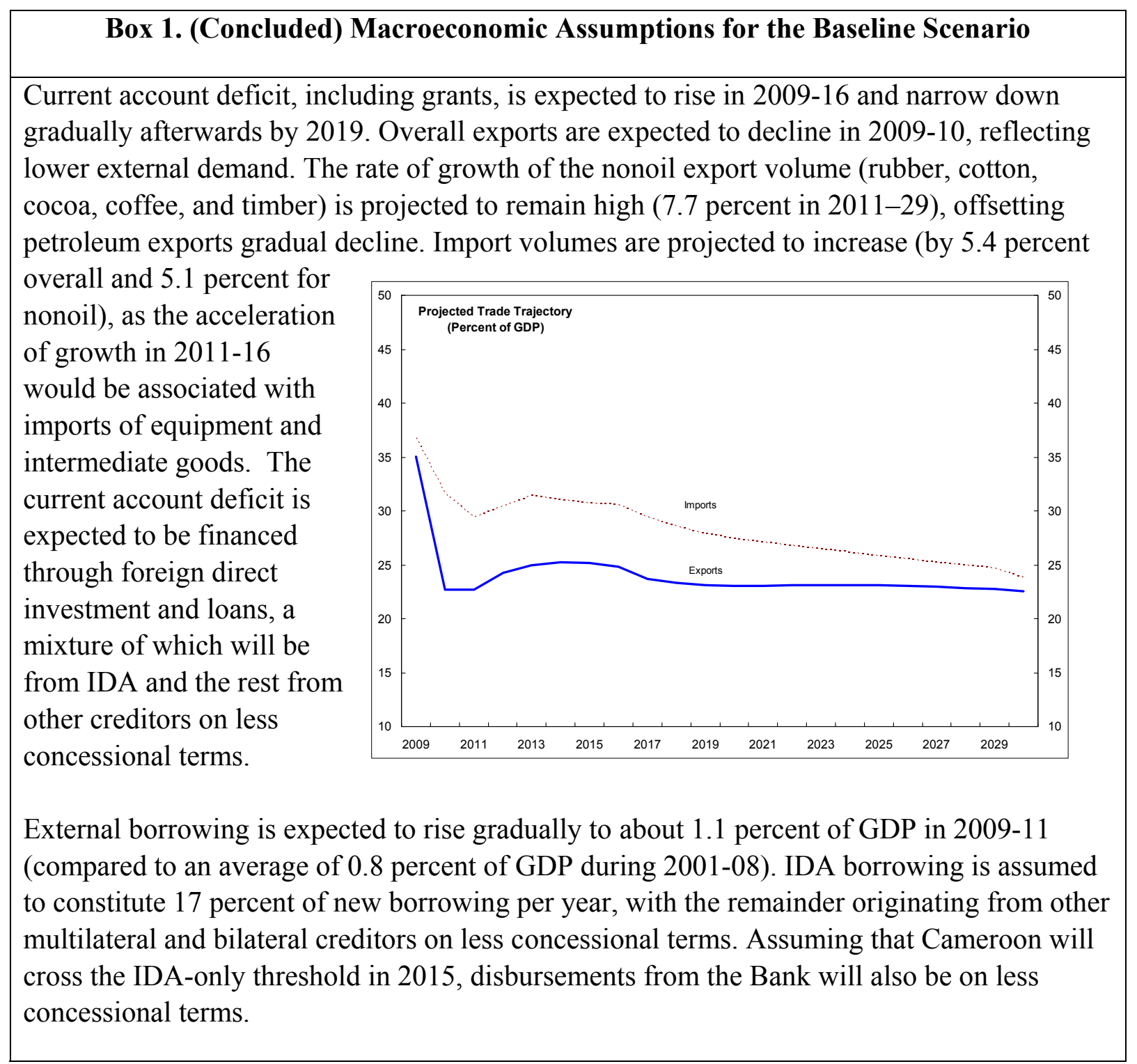

\section{EXternal Debt Sustainability}

\section{Baseline Scenario}

7. The analysis is guided by indicative, performance-based debt burden thresholds for external debt. The LIC debt sustainability framework (DSF) is guided by countryspecific debt burden thresholds based on the strength of a country's policies and institutions. These thresholds reflect the empirical findings that sustainable debt levels for a low-income country increase with the quality of its policies and institutions. Such quality is measured by the Country Policy and Institutional Assessment (CPIA) index, compiled annually by the 
World Bank. Cameroon now ranks as a 'weak performer' under the joint IMF/World Bank debt sustainability framework, based on its three-year moving average CPIA score. ${ }^{5}$ The indicative external debt burden thresholds for countries in this category are a PV of debt-toexports ratio of 100 percent, PV of debt-to-revenue ratio of 200 percent, a PV of debt-toGDP ratio of 30 percent, and debt-service-to-exports and revenues ratios of 15 and 25 percent, respectively.

8. Cameroon 's external debt appears sustainable. Under the baseline scenario, all debt indicators remain below their thresholds through 2029.

$>$ Text Table 3 and

Figure 3 show that all external debt ratios remain below their thresholds. The pace of increase of the PV of debt-to-exports ratio is projected to be steeper because oil exports, an important component of Cameroon's total export, are declining. The gradual and moderate rise in the $\mathrm{PV}$ of debt-to-exports ratio reflects the assumption that Cameroon's borrowing policy will continue to be prudent.

> The baseline scenario assumes concessional external borrowing (including the ESFRAC) to help fill the financing gaps associated with the global slowdown. Repayment could cluster in 2014 as debt contracted in 2009 and 2010 matures. Figure 3 shows that debt service ratios would peak in $2014-15$ but the debt situation would still be manageable.

\section{Alternative Scenario and Stress Tests}

\section{Alternative scenarios and bound tests show that debt indicators remain below their thresholds through 2029.}

$>$ In the scenario where new borrowing occurs on less concessional terms, which assumes

\footnotetext{
${ }^{5}$ Cameroon's CPIA declined from 3.3 to 3.2 between 2005 and 2006 and remained at that level in 2007, thus the average CPIA rating for Cameroon for the last three years is 3.25-the rating for weak performers . The downgrade is the result of a deterioration in the following criteria: business regulatory environment; policies and institutions for environmental sustainability; structural policy cluster; and efficiency of revenue mobilization.
} 
that the interest rate on new borrowing through 2029 is 2 percentage points higher than in the baseline, all debt ratios do deteriorate but stay below the thresholds. Deviations from the baseline occur as repayments cluster.

$>$ The historical average scenario, which is associated with past current account surpluses, is unlikely to occur, as oil production is expected to taper off in the next 20 years. This scenario shows a more optimistic debt ratio trajectory relative to the baseline. Thus, in terms of the risk assessment the historic scenario is irrelevant and, as such, is therefore omitted from Figure 3.

$>$ Bound tests, including a one-time 30 percent depreciation, lead to similar conclusions. The scenario of real GDP at the historical average minus one standard deviation in 2010-11, which implies 0.7 percentage point above the baseline projection, suggests that government would close the implied financing need by borrowing at similar conditions as in the baseline. As a result, the PV of debt-to-GDP ratio starts rising moderately over time and eventually levels off. However, the scenario where exports grow at the historical average minus one standard deviation in 2010-11, suggests a more pronounced shift in debt burden, and the PV of external debt reaches 94 percent of GDP in 2029 (below its threshold of 100 percent).

\section{Public Sector Debt Sustainability ${ }^{6}$}

10. The DSA shows that public debt sustainability will be preserved. The nonoil primary deficit is expected to deteriorate over the medium term in support of the country's development needs. New borrowing will amount to about 1 percent of GDP annually during 2009-16, consistent with the country's absorption capacity and will then gradually decline over the long term. ${ }^{7}$ In the baseline scenario, the debt ratio will rise gradually over the long-term. The PV of debt-to-GDP and debt-to-revenue ratios is expected to rise over time, with some reduction in outer years. Debt service will follow a similar pattern and stay at a comfortable level through 2029.

11. Stress tests indicate that all debt indicators (PV of debt-to-revenue ratio, $\mathrm{PV}$ of debt-to-revenue ratio, and debt service-to-revenue ratio) remain on stable paths and do not reveal particular vulnerabilities. However, the scenario of a contingent liability shock amounting to 10 percent of GDP shows some more sensitive debt dynamic relative to the baseline.

\footnotetext{
${ }^{6}$ The historical average scenario, which is associated with past primary surpluses, is unlikely to occur, as oil production is expected to taper off in the next 20 years. This scenario shows a more optimistic debt ratio trajectory relative to the baseline.

${ }^{7}$ Insufficient institutional and administrative capacity has so far kept Cameroon from scaling up foreignfinanced investment above 0.5 to 1 percentage point of GDP annually.
} 


\section{Despite its low risk of debt distress, Cameroon has stepped up efforts to} strengthen its debt management framework. Following joint Bank-Fund technical assistance, the authorities are working to implement a new debt management strategy aligned with CEMAC guidelines. The authorities have themselves started producing a DSA and are formulating a medium-term debt management strategy (MTDS) for central government debt, using the Bank-Fund toolkit.

\section{CONClusion}

13. Cameroon's risk of debt distress remains low. All external debt ratios remain well below the policy-dependent thresholds. However, because of the global financial crisis and economic slowdown, debt indicators are somewhat higher than in the 2008 DSA. Debt indicators rise under alternative scenario and bound tests, but not beyond country-specific debt burden thresholds, when assessing external sustainability, and remain at a comfortable level in regards to public debt sustainability.

14. However, persistent weakness in public finance management and insufficient data coverage remain areas of vulnerability in Cameroon's assessment. In particular, these vulnerabilities refer to quasi-fiscal liabilities of state-owned enterprises and a possible build up of new arrears since the 2005 audit, for which available information is limited. The authorities' efforts to improve debt management could be reinforced by steps to ensure better coverage of public sector liabilities and by a new audit to clarify whether new domestic arrears have emerged since 2005. In addition, continued efforts to achieve greater nonoil revenue mobilization and to widen the export base would be advisable, given the expected long-run decline in oil revenue. 
Figure 3. Cameroon: Indicators of Public- and Publicly-Guaranteed External Debt under Alternatives Scenarios, 2009-2029 1/
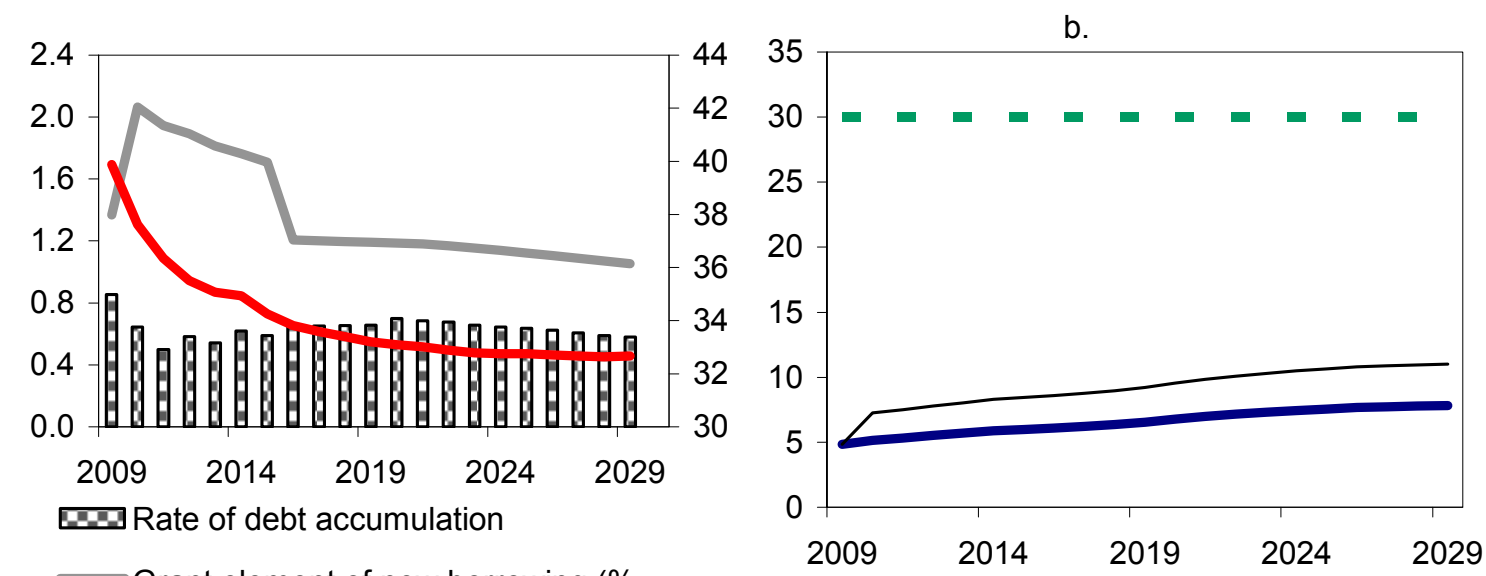

Grant element of new borrowing (\% right scale)

Grant-equivalent financing (\% of GDP)
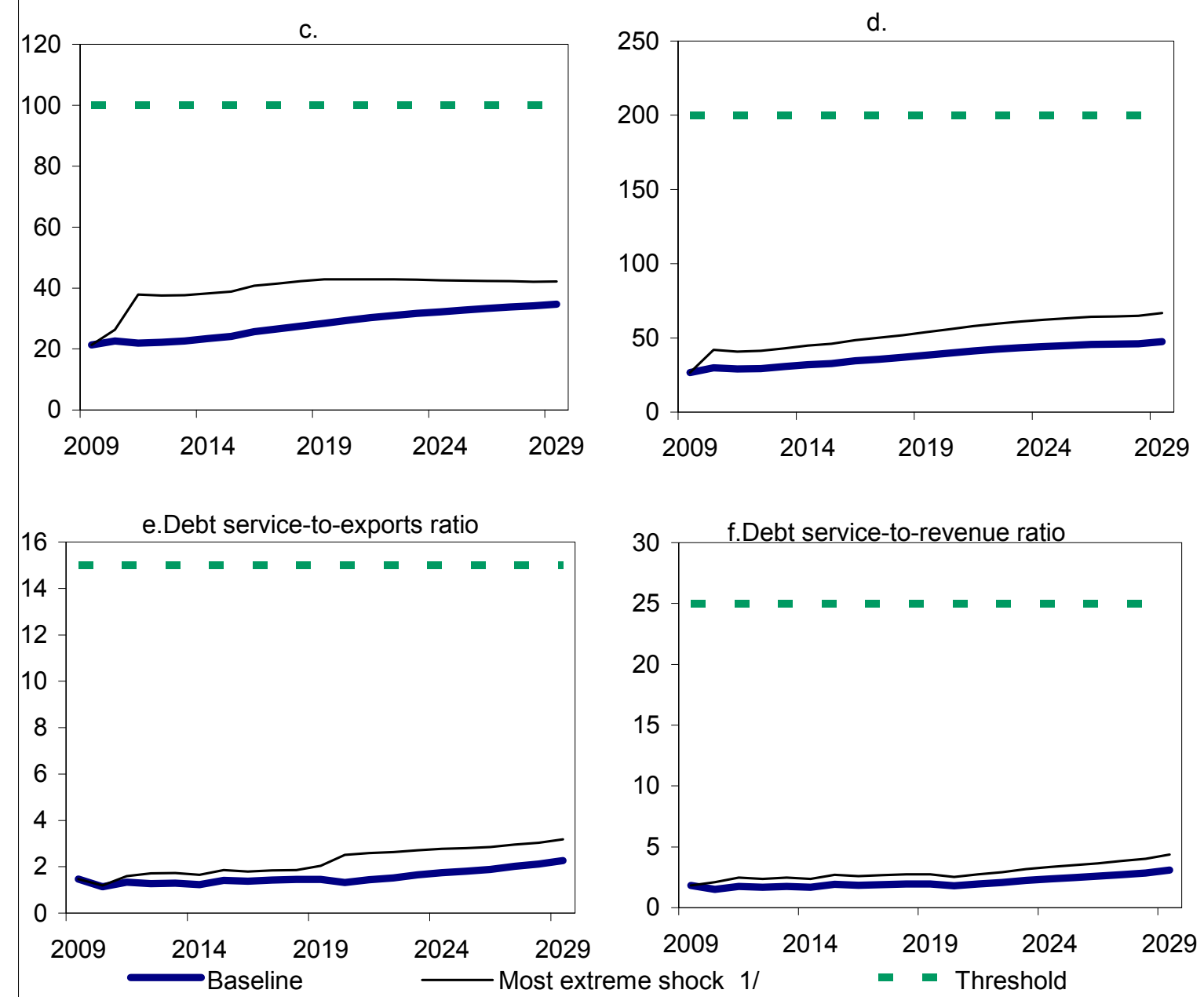

Source: Staff projections and simulations.

1/ The most extreme stress test is the test that yields the highest ratio in 2019. In Figure (b) it corresponds to a Onetime depreciation shock; in (c) to a Exports shock; in (d) to a One-time depreciation shock; in (e) to an Exports shock and in Figure (f) to a One-time depreciation shock. 
Figure 4. Cameroon: Indicators of Public Debt Under Alternative Scenarios, 2009-2029 1/
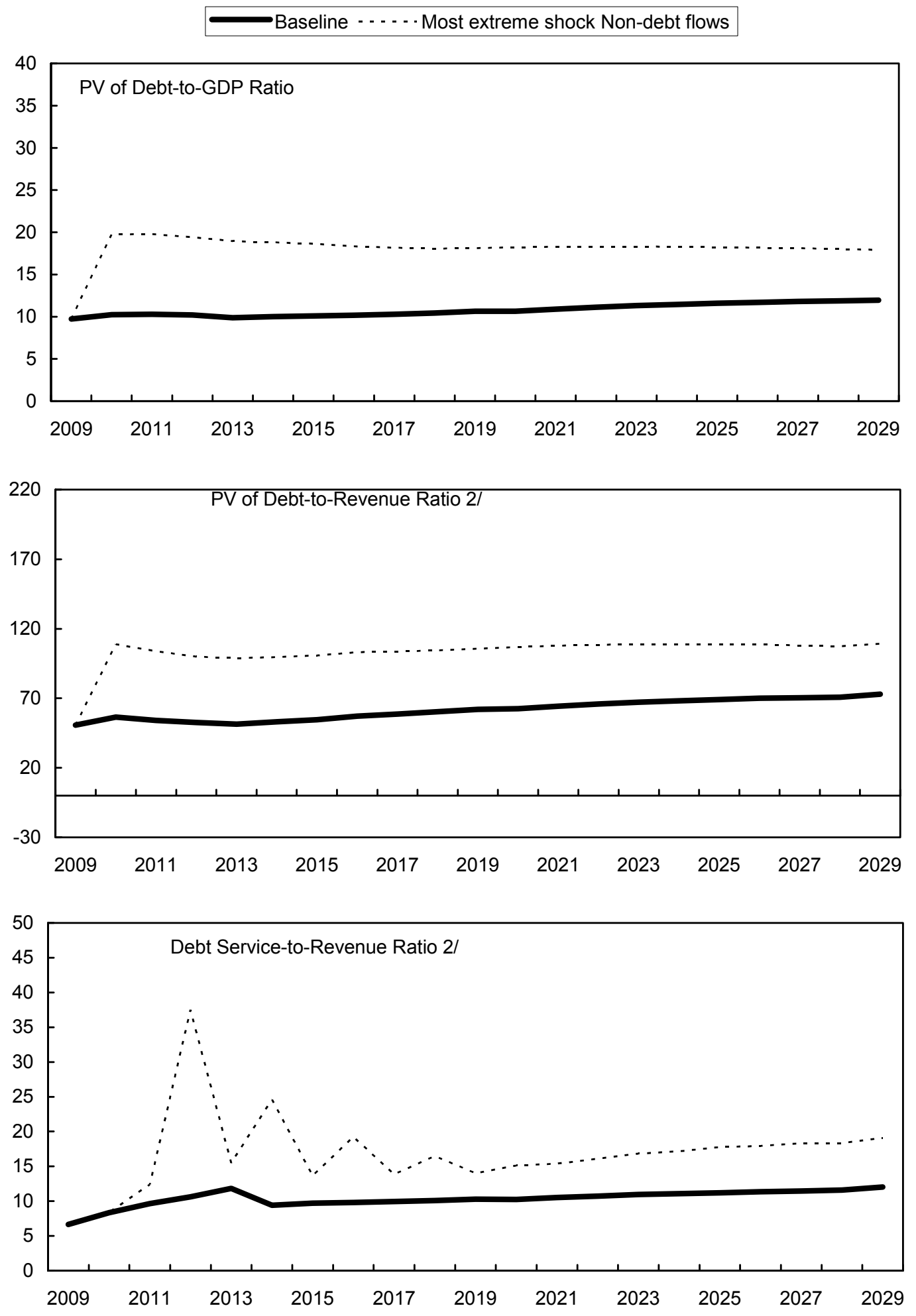

Sources: Country authorities; and Fund staff estimates and projections.

$1 /$ The most extreme stress test is the test that yields the highest ratio in 2019.

2/ Revenues are defined inclusive of grants. 
Table 1a.Cameroon: Public Sector Debt Sustainability Framework, Baseline Scenario, 2006-29 (In percent of GDP, unless otherwise indicated)

\begin{tabular}{|c|c|c|c|c|c|c|c|c|c|c|c|c|c|c|c|}
\hline & \multicolumn{3}{|c|}{ Actual } & \multirow[b]{2}{*}{$\begin{array}{r}\text { 1999-2008 } \\
\text { Average }\end{array}$} & \multirow[b]{2}{*}{$\begin{array}{l}\text { Standard } \\
\text { Deviation }\end{array}$} & \multicolumn{5}{|l|}{ Estimate } & \multicolumn{5}{|c|}{ ojections } \\
\hline & 2006 & 2007 & 2008 & & & 2009 & 2010 & 2011 & 2012 & 2013 & 2014 & $\begin{array}{l}2009-14 \\
\text { Average }\end{array}$ & 2019 & 2029 & $\begin{array}{l}2015-29 \\
\text { Average }\end{array}$ \\
\hline $\begin{array}{l}\text { Public sector debt } 1 / \\
\text { o/w foreign-currency denominated }\end{array}$ & $\begin{array}{r}15.7 \\
6.3\end{array}$ & $\begin{array}{r}11.8 \\
5.6\end{array}$ & $\begin{array}{l}9.8 \\
5.5\end{array}$ & & & $\begin{array}{r}12.4 \\
7.5\end{array}$ & $\begin{array}{r}13.1 \\
8.0\end{array}$ & $\begin{array}{r}13.2 \\
8.3\end{array}$ & $\begin{array}{r}13.3 \\
8.6\end{array}$ & $\begin{array}{r}13.0 \\
8.8\end{array}$ & $\begin{array}{r}13.2 \\
9.1\end{array}$ & & $\begin{array}{r}13.8 \\
9.7\end{array}$ & $\begin{array}{l}14.9 \\
10.8\end{array}$ & \\
\hline $\begin{array}{l}\text { Change in public sector debt } \\
\text { dentified debt-creating flows }\end{array}$ & $\begin{array}{l}-36.1 \\
-392\end{array}$ & $\begin{array}{l}-3.9 \\
-8.8\end{array}$ & $\begin{array}{l}-2.0 \\
-5.0\end{array}$ & & & $\begin{array}{r}2.6 \\
-2.4\end{array}$ & $\begin{array}{r}0.7 \\
-2.1\end{array}$ & $\begin{array}{r}0.1 \\
-27\end{array}$ & $\begin{array}{r}0.0 \\
-26\end{array}$ & $\begin{array}{l}-0.3 \\
-2.1\end{array}$ & $\begin{array}{r}0.2 \\
-18\end{array}$ & & $\begin{array}{l}0.2 \\
0.4\end{array}$ & $\begin{array}{l}0.0 \\
0.7\end{array}$ & \\
\hline Primary deficit & -33.6 & -4.7 & -1.5 & -6.6 & 9.6 & -0.7 & 0.3 & -0.7 & -0.9 & -0.5 & -0.2 & -0.5 & 1.6 & 1.4 & 1.5 \\
\hline Revenue and grants & 47.6 & 20.0 & 21.3 & & & 19.2 & 18.1 & 19.1 & 19.4 & 19.1 & 18.9 & & 17.3 & 16.6 & \\
\hline of which: grants & 28.4 & 1.2 & 0.9 & & & 1.0 & 0.8 & 0.7 & 0.5 & 0.5 & 0.4 & & 0.2 & 0.1 & \\
\hline Primary (noninterest) expenditure & 14.0 & 15.3 & 19.8 & & & 18.5 & 18.4 & 18.4 & 18.5 & 18.6 & 18.7 & & 18.9 & 18.0 & \\
\hline Automatic debt dynamics & -3.8 & -1.1 & -0.8 & & & 0.7 & -0.4 & -0.5 & -0.5 & -0.5 & -0.6 & & -0.5 & -0.6 & \\
\hline Contribution from interest rate/growth differential & -2.7 & -0.6 & -0.5 & & & 0.0 & -0.2 & -0.4 & -0.4 & -0.5 & -0.5 & & -0.5 & 0.1 & \\
\hline of which: contribution from average real interest rate & -1.1 & -0.1 & -0.1 & & & 0.3 & 0.1 & 0.1 & 0.1 & 0.1 & 0.1 & & 0.1 & 0.7 & \\
\hline of which: contribution from real GDP growth & -1.6 & -0.5 & -0.4 & & & -0.2 & -0.3 & -0.5 & -0.5 & -0.6 & -0.6 & & -0.6 & -0.6 & \\
\hline Contribution from real exchange rate depreciation & -1.1 & -0.5 & -0.3 & & & 0.7 & -0.2 & -0.1 & 0.0 & 0.0 & 0.0 & & $\ldots$ & $\ldots$ & \\
\hline Other identified debt-creating flows & -1.8 & -3.0 & -2.7 & & & -2.4 & -2.0 & -1.6 & -1.2 & -1.1 & -1.0 & & -0.7 & -0.1 & \\
\hline Privatization receipts (negative) & 0.0 & 0.0 & 0.0 & & & 0.0 & 0.0 & 0.0 & 0.0 & 0.0 & 0.0 & & 0.0 & 0.0 & \\
\hline Recognition of implicit or contingent liabilities & 0.0 & 0.0 & 0.0 & & & 0.0 & 0.0 & 0.0 & 0.0 & 0.0 & 0.0 & & 0.0 & 0.0 & \\
\hline Debt relief (HIPC and other) & -1.8 & -3.0 & -2.7 & & & -2.4 & -2.0 & -1.6 & -1.2 & -1.1 & -1.0 & & -0.7 & -0.1 & \\
\hline Other (specify, e.g. bank recapitalization) & 0.0 & 0.0 & 0.0 & & & 0.0 & 0.0 & 0.0 & 0.0 & 0.0 & 0.0 & & 0.0 & 0.0 & \\
\hline Residual, including asset changes & 3.1 & 4.8 & 3.0 & & & 5.1 & 2.8 & 2.9 & 2.6 & 1.8 & 2.0 & & -0.1 & -0.7 & \\
\hline \multicolumn{16}{|l|}{ Other Sustainability Indicators } \\
\hline PV of public sector debt & 9.4 & 6.1 & 7.8 & & & 9.7 & 10.2 & 10.3 & 10.2 & 9.9 & 10.0 & & 10.6 & 12.0 & \\
\hline $\mathrm{o} / \mathrm{W}$ foreign-currency denominated & 0.0 & 0.0 & 3.6 & & & 4.8 & 5.1 & 5.3 & 5.5 & 5.7 & 5.9 & & 6.6 & 7.8 & \\
\hline o/w external & $\ldots$ & $\ldots$ & 3.6 & & & 4.8 & 5.1 & 5.3 & 5.5 & 5.7 & 5.9 & & 6.6 & 7.8 & \\
\hline PV of contingent liabilities (not included in public sector debt) & & $\ldots$ & & & & $\ldots$ & & $\ldots$ & & & $\ldots$ & & & & \\
\hline Gross financing need $2 /$ & -28.3 & -2.2 & 0.4 & & & 0.6 & 1.8 & 1.2 & 1.1 & 1.8 & 1.5 & & 3.3 & 3.4 & \\
\hline PV of public sector debt-to-revenue and grants ratio (in percent) & 19.8 & 30.6 & 36.7 & & & 50.8 & 56.5 & 54.0 & 52.5 & 51.6 & 53.0 & & 61.5 & 72.2 & \\
\hline PV of public sector debt-to-revenue ratio (in percent) & 49.0 & 32.6 & 38.3 & & & 53.7 & 59.2 & 56.1 & 54.0 & 52.9 & 54.3 & & 62.1 & 72.4 & \\
\hline o/w external $3 /$ & & & 17.5 & & & 26.5 & 29.8 & 29.0 & 29.3 & 30.6 & 31.9 & & 38.2 & 47.4 & \\
\hline Debt service-to-revenue and grants ratio (in percent) $4 /$ & 11.1 & 12.5 & 8.9 & & & 6.6 & 8.3 & 9.6 & 10.6 & 11.9 & 9.4 & & 10.2 & 11.9 & \\
\hline Debt service-to-revenue ratio (in percent) $4 /$ & 27.5 & 13.3 & 9.2 & & & 7.0 & 8.7 & 10.0 & 10.9 & 12.2 & 9.6 & & 10.3 & 11.9 & \\
\hline Primary deficit that stabilizes the debt-to-GDP ratio & 2.5 & -0.7 & 0.5 & & & -3.4 & -0.4 & -0.8 & -1.0 & -0.2 & -0.5 & & 1.3 & 1.4 & \\
\hline \multicolumn{16}{|l|}{ Key macroeconomic and fiscal assumptions } \\
\hline Real GDP growth (in percent) & 3.2 & 3.5 & 3.4 & 3.6 & 1.0 & 2.4 & 2.6 & 4.0 & 4.2 & 4.5 & 5.2 & 3.8 & 5.0 & 4.5 & 5.2 \\
\hline Average nominal interest rate on forex debt (in percent) & 1.1 & 1.4 & 1.4 & 3.1 & 2.0 & 1.7 & 1.2 & 1.5 & 1.5 & 1.5 & 1.5 & 1.5 & 1.4 & 1.4 & 1.4 \\
\hline Average real interest rate on domestic debt (in percent) & -2.7 & -0.5 & -0.7 & -0.6 & 1.8 & 5.4 & 0.7 & 1.9 & 2.5 & 3.1 & 3.7 & 2.9 & 3.9 & 3.5 & 3.8 \\
\hline Real exchange rate depreciation (in percent,+ indicates depreciation) & -3.0 & -7.6 & -5.6 & -6.0 & 3.9 & 12.6 & & $\ldots$ & & & $\ldots$ & $\ldots$ & $\ldots$ & $\ldots$ & $\ldots$ \\
\hline Inflation rate (GDP deflator, in percent) & 3.9 & 2.1 & 1.5 & 2.4 & 1.7 & -3.3 & 2.4 & 2.0 & 2.0 & 2.0 & 2.1 & 1.2 & 2.0 & 2.3 & 2.0 \\
\hline Growth of real primary spending (deflated by GDP deflator, in percent) & 0.0 & 0.1 & 0.3 & 0.1 & 0.1 & 0.0 & 0.0 & 0.0 & 0.0 & 0.1 & 0.1 & 0.0 & 0.0 & 0.0 & 0.0 \\
\hline Grant element of new external borrowing (in percent) & & $\ldots$ & 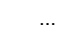 & $\ldots$ & & 38.0 & 42.0 & 41.4 & 41.0 & 40.6 & 40.3 & 40.5 & 37.0 & 36.1 & \\
\hline
\end{tabular}

Sources: Country authorities; and Fund staff estimates and projections.

Tous

deficit plus debt service plus the stock of short-term debt at the end of the last period.

$4 /$ Debt service is defined as the sum of interest and amortization of medium and long-term debt. 
Table 2a.Cameroon: Sensitivity Analysis for Key Indicators of Public Debt, 2009-29

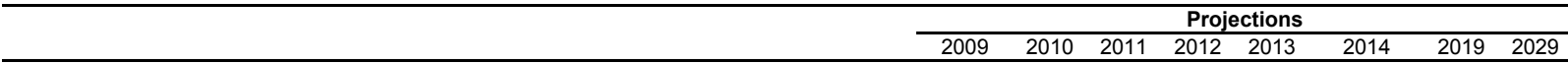

\section{Baseline}

\section{A. Alternative scenarios}

A1. Real GDP growth and primary balance are at historical averages

A2. Primary balance is unchanged from 2009

A3. Permanently lower GDP growth ${ }^{1}$

\section{B. Bound tests}

B1. Real GDP growth is at historical average minus one standard deviations in 2010-2011 B2. Primary balance is at historical average minus one standard deviations in 2010-2011 B3. Combination of B1-B2 using one half standard deviation shocks

B4. One-time 30 percent real depreciation in 2010

B5. 10 percent of GDP increase in other debt-creating flows in 2010

\section{Baseline}

\section{A. Alternative scenarios}

A1. Real GDP growth and primary balance are at historical averages A2. Primary balance is unchanged from 2009

A3. Permanently lower GDP growth

\section{B. Bound tests}

B1. Real GDP growth is at historical average minus one standard deviations in 2010-2011 B2. Primary balance is at historical average minus one standard deviations in 2010-2011

B3. Combination of B1-B2 using one half standard deviation shocks

B4. One-time 30 percent real depreciation in 2010

B5. 10 percent of GDP increase in other debt-creating flows in 2010

\section{Baseline}

\section{A. Alternative scenarios}

A1. Real GDP growth and primary balance are at historical averages A2. Primary balance is unchanged from 2009

A3. Permanently lower GDP growth ${ }^{1}$

\section{B. Bound tests}

B1. Real GDP growth is at historical average minus one standard deviations in 2010-2011 B2. Primary balance is at historical average minus one standard deviations in 2010-2011 B3. Combination of B1-B2 using one half standard deviation shocks

B4. One-time 30 percent real depreciation in 2010

B5. 10 percent of GDP increase in other debt-creating flows in 2010

\section{Baseline}

\section{A. Alternative scenarios}

A1. Real GDP growth and primary balance are at historical averages

A2. Primary balance is unchanged from 2006

A3. Permanently lower GDP growth ${ }^{1}$

\section{B. Bound tests}

B1. Real GDP growth is at historical average minus one standard deviations in 2008-2009

B2. Primary balance is at historical average minus one standard deviations in 2008-2009

B3. Combination of B1-B2 using one half standard deviation shocks

B4. One-time 30 percent real depreciation in 2008

B5. 10 percent of GDP increase in other debt-creating flows in 2008

\section{PV of Debt-to-GDP Ratio}

$\begin{array}{llllllll}10 & 10 & 10 & 10 & 10 & 10 & 11 & 12\end{array}$

$\begin{array}{rrrrrrrr}10 & 8 & 7 & 5 & 4 & 2 & 0 & 0 \\ 10 & 9 & 9 & 9 & 9 & 9 & 1 & 0 \\ 10 & 10 & 10 & 10 & 10 & 11 & 13 & 18\end{array}$

$\begin{array}{rrrrrrrr}10 & 10 & 11 & 11 & 11 & 11 & 13 & 16 \\ 10 & 7 & 5 & 5 & 5 & 5 & 7 & 9 \\ 10 & 7 & 4 & 5 & 4 & 5 & 7 & 9 \\ 10 & 12 & 12 & 12 & 11 & 11 & 11 & 13 \\ 10 & 20 & 20 & 19 & 19 & 19 & 18 & 18\end{array}$

PV of Debt-to-Revenue Ratio ${ }^{2}$

$\begin{array}{llllllll}51 & 56 & 54 & 53 & 52 & 53 & 62 & 72\end{array}$

$\begin{array}{rrrrrrrr}51 & 43 & 35 & 28 & 20 & 13 & 0 & 0 \\ 51 & 51 & 49 & 49 & 47 & 46 & 8 & 0 \\ 51 & 57 & 55 & 54 & 54 & 56 & 73 & 111\end{array}$

$\begin{array}{rrrrrrrr}51 & 57 & 56 & 56 & 56 & 59 & 73 & 94 \\ 51 & 40 & 28 & 28 & 27 & 29 & 39 & 54 \\ 51 & 37 & 23 & 23 & 23 & 25 & 38 & 56 \\ 51 & 67 & 63 & 60 & 59 & 59 & 66 & 77 \\ 51 & 109 & 104 & 100 & 99 & 100 & 105 & 108\end{array}$

Debt Service-to-Revenue Ratio ${ }^{2}$

Sources: Country authorities; and Fund staff estimates and projections.

$1 /$ Assumes that real GDP growth is at baseline minus one standard deviation divided by the length of the projection period.

2/ Revenues are defined inclusive of grants. 
Table 3a.: External Debt Sustainability Framework, Baseline Scenario, 2006-29 (In percent of GDP, unless otherwise indicated)

\begin{tabular}{|c|c|c|c|c|c|c|c|c|c|c|c|c|c|c|c|}
\hline & \multicolumn{3}{|c|}{ Actual } & \multirow{2}{*}{$\begin{array}{c}\text { 1999-2008 } \\
\text { Average }\end{array}$} & \multirow{2}{*}{$\begin{array}{l}\text { Standard } \\
\text { Deviation }\end{array}$} & \multicolumn{6}{|c|}{ Projections } & \multirow[b]{2}{*}{$\begin{array}{l}\text { 2009-2014 } \\
\text { Average } \\
\end{array}$} & \multirow[b]{2}{*}{2019} & \multirow[b]{2}{*}{2029} & \multirow[b]{2}{*}{$\begin{array}{c}\text { 2015-2029 } \\
\text { Average }\end{array}$} \\
\hline & 2006 & 2007 & 2008 & & & 2009 & 2010 & 2011 & 2012 & 2013 & 2014 & & & & \\
\hline External debt (nominal) 1 & 6.3 & 5.6 & 5.5 & & & 7.5 & 8.0 & 8.3 & 8.6 & 8.8 & 9.1 & & 9.7 & 10.8 & \\
\hline $\mathrm{o} / \mathrm{w}$ public and publicly guaranteed (PPG) & 6.3 & 5.6 & 5.5 & & & 7.5 & 8.0 & 8.3 & 8.6 & 8.8 & 9.1 & & 9.7 & 10.8 & \\
\hline Change in external debt & -31.4 & -0.6 & -0.1 & & & 2.0 & 0.5 & 0.3 & 0.4 & 0.2 & 0.2 & & 0.2 & 0.0 & \\
\hline Identified net debt-creating flows & -4.2 & -0.9 & 0.0 & & & 4.8 & 3.1 & 2.4 & 2.1 & 2.1 & 1.9 & & 1.6 & 0.0 & \\
\hline Non-interest current account deficit & -1.0 & 0.7 & 1.0 & 1.5 & 1.5 & 5.8 & 4.1 & 3.5 & 3.2 & 3.1 & 3.0 & & 2.5 & 0.7 & 1.9 \\
\hline Deficit in balance of goods and services & 1.2 & 1.6 & 1.8 & & & 8.9 & 6.7 & 6.2 & 6.4 & 5.8 & 5.5 & & 4.4 & 1.3 & \\
\hline Exports & 28.1 & 32.7 & 35.0 & & & 22.7 & 22.7 & 24.2 & 25.0 & 25.2 & 25.1 & & 23.1 & 22.6 & \\
\hline Imports & 29.3 & 34.3 & 36.8 & & & 31.6 & 29.4 & 30.4 & 31.4 & 31.0 & 30.7 & & 27.5 & 23.9 & \\
\hline Net current transfers (negative $=$ inflow) & -1.4 & -2.0 & -1.8 & -1.5 & 0.4 & -1.7 & -1.9 & -2.1 & -2.3 & -2.2 & -2.1 & & -1.5 & -0.8 & -1.3 \\
\hline $\mathrm{o} / \mathrm{w}$ official & 0.0 & 0.0 & 0.0 & & & 0.0 & 0.0 & 0.0 & 0.0 & 0.0 & 0.0 & & 0.0 & 0.0 & \\
\hline Other current account flows (negative = net inflow) & -0.7 & 1.1 & 0.9 & & & -1.4 & -0.7 & -0.6 & -0.9 & -0.4 & -0.4 & & -0.4 & 0.1 & \\
\hline Net FDI (negative $=$ inflow) & -0.7 & -0.8 & -0.4 & -0.3 & 0.3 & -1.0 & -0.9 & -0.9 & -0.8 & -0.8 & -0.8 & & -0.6 & -0.3 & -0.5 \\
\hline Endogenous debt dynamics 2 & -2.5 & -0.8 & -0.5 & & & 0.0 & -0.1 & -0.2 & -0.2 & -0.2 & -0.3 & & -0.3 & -0.3 & \\
\hline Contribution from nominal interest rate & 0.4 & 0.1 & 0.1 & & & 0.1 & 0.1 & 0.1 & 0.1 & 0.1 & 0.1 & & 0.1 & 0.1 & \\
\hline Contribution from real GDP growth & -1.1 & -0.2 & -0.2 & & & -0.1 & -0.2 & -0.3 & -0.3 & -0.4 & -0.4 & & -0.4 & -0.5 & \\
\hline Contribution from price and exchange rate changes & -1.7 & -0.6 & -0.4 & & & & & & & & & & 0.7 & & \\
\hline $\begin{array}{l}\text { Residual (3-4) }{ }^{3} \\
\text { o/w exceptional financing }\end{array}$ & -27.2 & $\begin{array}{l}0.3 \\
0.0\end{array}$ & $\begin{array}{r}-0.1 \\
0.0\end{array}$ & -4.9 & 10.0 & -2.8 & -2.6 & -2.1 & -1.8 & -1.8 & -1.7 & -2.1 & -1.4 & 0.0 & -0.9 \\
\hline o/w exceptional financing & -1.0 & & 0.0 & & & 0.0 & 0.0 & 0.0 & 0.0 & 0.0 & 0.0 & & 0.0 & 0.0 & \\
\hline$P V$ of external debt ${ }^{4}$ & $\ldots$ & $\ldots$ & 3.6 & & & 4.8 & 5.2 & 5.3 & 5.5 & 5.7 & 5.9 & & 6.5 & 7.8 & \\
\hline In percent of exports & $\ldots$ & $\ldots$ & 10.2 & & & 21.3 & 22.7 & 21.9 & 22.2 & 22.6 & 23.4 & & 28.4 & 34.7 & \\
\hline PV of PPG external debt & $\ldots$ & $\ldots$ & 3.6 & & & 4.8 & 5.2 & 5.3 & 5.5 & 5.7 & 5.9 & & 6.5 & 7.8 & \\
\hline In percent of exports & $\ldots$ & $\ldots$ & 10.2 & & & 21.3 & 22.7 & 21.9 & 22.2 & 22.6 & 23.4 & & 28.4 & 34.7 & \\
\hline In percent of governm & $\ldots$ & $\ldots$ & 17.5 & & & 26.6 & 29.8 & 29.0 & 29.3 & 30.6 & 31.9 & & 38.2 & 47.4 & \\
\hline Debt service-to-exports ratio (in percent) & 5.2 & 0.8 & 0.7 & & & 1.5 & 1.1 & 1.3 & 1.3 & 1.3 & 1.2 & & 1.5 & 2.3 & \\
\hline PPG debt service-to-exports ratio (in percent) & 5.2 & 0.8 & 0.7 & & & 1.5 & 1.1 & 1.3 & 1.3 & 1.3 & 1.2 & & 1.5 & 2.3 & \\
\hline PPG debt service-to-revenue ratio (in percent) & 7.6 & 1.4 & 1.2 & & & 1.8 & 1.5 & 1.8 & 1.7 & 1.8 & 1.7 & & 2.0 & 3.1 & \\
\hline Total gross financing need (Billions of U.S. dollars) & 0.0 & 0.0 & 0.2 & & & 1.1 & 0.8 & 0.7 & 0.7 & 0.7 & 0.7 & & 1.0 & 0.7 & \\
\hline Non-interest current account deficit that stabilizes debt ratio & 30.4 & 1.3 & 1.1 & & & 3.8 & 3.6 & 3.2 & 2.8 & 2.9 & 2.8 & & 2.3 & 0.7 & \\
\hline \multicolumn{16}{|l|}{ Key macroeconomic assumptions } \\
\hline Real GDP growth (in percent) & 3.2 & 3.5 & 3.4 & 3.6 & 1.0 & 2.4 & 2.6 & 4.0 & 4.2 & 4.5 & 5.2 & 3.8 & 5.0 & 4.5 & 5.2 \\
\hline GDP deflator in US dollar terms (change in percent) & 4.8 & 11.3 & 8.6 & 5.5 & 8.5 & -10.7 & 3.6 & 2.2 & 2.1 & 2.0 & 2.1 & 0.2 & 2.0 & 2.3 & 2.0 \\
\hline Effective interest rate (percent) 5 & 1.1 & 1.4 & 1.4 & 3.1 & 2.0 & 1.7 & 1.2 & 1.5 & 1.5 & 1.5 & 1.5 & 1.5 & 1.4 & 1.4 & 1.4 \\
\hline Growth of exports of G\&S (US dollar terms, in percent) & 24.4 & 33.8 & 20.4 & 14.2 & 12.0 & -40.6 & 6.5 & 13.3 & 9.8 & 7.7 & 7.1 & 0.6 & 6.9 & 5.8 & 6.6 \\
\hline Growth of imports of G\&S (US dollar terms, in percent) & 7.3 & 34.8 & 20.6 & 12.3 & 9.4 & -21.3 & -1.0 & 10.0 & 9.8 & 5.4 & 6.2 & 1.5 & 5.5 & 3.5 & 5.5 \\
\hline Grant element of new public sector b & & & & & $\ldots$ & 38.0 & 42.0 & 41.4 & 41.0 & 40.6 & 40.3 & 40.5 & 37.0 & 36.1 & 36.9 \\
\hline ercent of GDP) & 19.3 & 18.8 & 20.4 & & & 18.1 & 17.3 & 18.4 & 18.9 & 18.7 & 18.5 & & 17.1 & 16.5 & 17.1 \\
\hline Aid flows (in Billions of US dollars) 6 & 5.1 & 0.2 & 0.2 & & & 0.4 & 0.4 & 0.3 & 0.3 & 0.3 & 0.3 & & 0.4 & 0.7 & \\
\hline o/w Grants & 5.1 & 0.2 & 0.2 & & & 0.2 & 0.2 & 0.2 & 0.1 & 0.1 & 0.1 & & 0.1 & 0.1 & \\
\hline $\mathrm{o} / \mathrm{w}$ Concessional loans & 0.0 & 0.0 & 0.0 & & & 0.2 & 0.2 & 0.2 & 0.2 & 0.2 & 0.2 & & 0.3 & 0.6 & \\
\hline Grant-equivalent financing (in percent of GDP) $\quad 7$ & $\ldots$ & $\ldots$ & $\ldots$ & & & 1.7 & 1.3 & 1.1 & 0.9 & 0.9 & 0.8 & & 0.5 & 0.5 & 0.5 \\
\hline Grant-equivalent financing (in percent of external financing) & $\ldots$ & $\ldots$ & $\ldots$ & & & 61.7 & 67.2 & 66.4 & 60.6 & 60.1 & 57.6 & & 45.7 & 39.9 & 44.3 \\
\hline \multicolumn{16}{|l|}{ Memorandum items: } \\
\hline Nominal GDP (Billions of US dollars) & 18.0 & 20.7 & 23.2 & & & 21.3 & 22.6 & 24.1 & 25.6 & 27.3 & 29.3 & & 43.4 & 84.6 & \\
\hline Nominal dollar GDP growth & 8.2 & 15.2 & 12.3 & & & -8.5 & 6.4 & 6.3 & 6.4 & 6.6 & 7.4 & 4.1 & 7.1 & 6.9 & 7.3 \\
\hline PV of PPG external debt (in Billions of US dollars) & & & 0.8 & & & 1.0 & 1.2 & 1.3 & 1.4 & 1.6 & 1.7 & & 2.8 & 6.6 & \\
\hline (PVt-PVt-1)/GDPt-1 (in percent) & & & & & & 0.9 & 0.6 & 0.5 & 0.6 & 0.5 & 0.6 & 0.6 & 0.7 & 0.6 & 0.6 \\
\hline
\end{tabular}

Source: Staff simulations.

'Includes both public and private sector external debt.

${ }^{2}$ Derived as $[r-g-r(1+g)](1+g+r+g r)$ times previous period debt ratio, with $r=$ nominal interest rate; $g=$ real GDP growth rate, and $r=$ growth rate of GDP deflator in U.S. dollar terms.

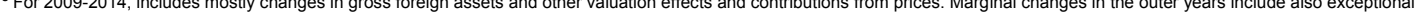

financing (i.e., changes in arrears and debt relief); changes in gross foreign assets; and valuation adjustments. For projections also includes contribution from price and exchange rate changes.

Assumes that PV of privale sector debt is equivalent to its face value.

6 Current-year interest payments divided by previous per.
6 Defined as grants, concessional loans, and debt relief.

${ }^{7}$ Grant-equivalent financing includes grants provided directly to the government and through new borrowing (difference between the face value and the PV of new debt). 
Table 3b.Cameroon: Sensitivity Analysis for Key Indicators of Public and Publicly Guaranteed External Debt, 2009-29 (In percent)

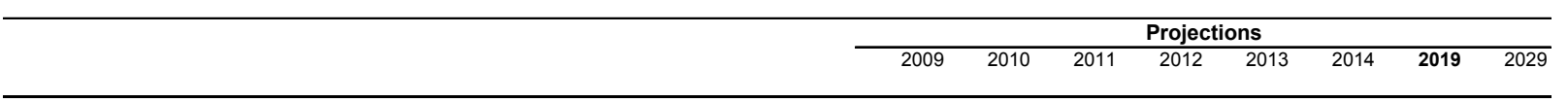

\section{Baseline}

\section{A. Alternative Scenarios}

A1. Key variables at their historical averages in $2009-2029^{1}$

A2. New public sector loans on less favorable terms in $2009-2029^{2}$

\section{B. Bound Tests}

B1. Real GDP growth at historical average minus one standard deviation in 2010-2011

B2. Export value growth at historical average minus one standard deviation in 2010-2011 ${ }^{3}$

B3. US dollar GDP deflator at historical average minus one standard deviation in 2010-2011

B4. Net non-debt creating flows at historical average minus one standard deviation in 2010-2011 ${ }^{4}$

B5. Combination of B1-B4 using one-half standard deviation shocks

B6. One-time 30 percent nominal depreciation relative to the baseline in $2010^{5}$

\section{Baseline}

\section{A. Alternative Scenarios}

A1. Key variables at their historical averages in 2009-2029 1/

A2. New public sector loans on less favorable terms in 2009-2029 2

\section{B. Bound Tests}

B1. Real GDP growth at historical average minus one standard deviation in 2010-2011

B2. Export value growth at historical average minus one standard deviation in 2010-2011

B3. US dollar GDP deflator at historical average minus one standard deviation in 2010-2011

B4. Net non-debt creating flows at historical average minus one standard deviation in 2010-2011

B5. Combination of B1-B4 using one-half standard deviation shocks

B6. One-time 30 percent nominal depreciation relative to the baseline in $2010^{5}$

\section{Baseline}

\section{A. Alternative Scenarios}

A1. Key variables at their historical averages in 2009-2029 1/

A2. New public sector loans on less favorable terms in 2009-2029 2

\section{B. Bound Tests}

B1. Real GDP growth at historical average minus one standard deviation in 2010-2011

B2. Export value growth at historical average minus one standard deviation in 2010-2011 ${ }^{3}$

B3. US dollar GDP deflator at historical average minus one standard deviation in 2010-2011

B4. Net non-debt creating flows at historical average minus one standard deviation in 2010-2011 ${ }^{4}$

B5. Combination of B1-B4 using one-half standard deviation shocks

B6. One-time 30 percent nominal depreciation relative to the baseline in $2010^{5}$

\section{PV of debt-to GDP ratio}

5
5

$\begin{array}{ll}5 & 5 \\ 5 & 6\end{array}$

5

$\begin{array}{rrrrrrr}5 & 5 & 6 & 6 & 6 & \mathbf{7} & 8 \\ 6 & 8 & 8 & 8 & 8 & 9 & 8 \\ 6 & 6 & 6 & 6 & 7 & \mathbf{7} & 9 \\ 6 & 8 & 8 & 8 & 8 & \mathbf{8} & 8 \\ 6 & 8 & 8 & 8 & 8 & \mathbf{8} & 8 \\ 7 & 7 & 8 & 8 & 8 & 9 & 11\end{array}$

\section{PV of debt-to-exports ratio}

21
22

22

23

23

28

35

$\begin{array}{llllllll}21 & 20 & 21 & 22 & 24 & 32 & 74\end{array}$

$\begin{array}{llllllll}21 & 23 & 22 & 22 & 23 & 23 & \mathbf{2 8} & 35 \\ 21 & 26 & 38 & 38 & 38 & 38 & \mathbf{4 3} & 42 \\ 21 & 23 & 22 & 22 & 23 & 23 & \mathbf{2 8} & 35 \\ 21 & 28 & 32 & 31 & 31 & 32 & \mathbf{3 9} & 38 \\ 21 & 25 & 32 & 32 & 32 & 32 & \mathbf{3 7} & 37 \\ 21 & 23 & 22 & 22 & 23 & 23 & \mathbf{2 8} & 35\end{array}$

\section{PV of debt-to-revenue ratio}

$\begin{array}{rrrrrrrr}27 & 30 & 29 & 29 & 31 & 32 & \mathbf{3 8} & 47 \\ & & & & & & & \\ 27 & 27 & 26 & 28 & 30 & 32 & \mathbf{4 3} & 102 \\ 27 & 30 & 29 & 29 & 31 & 32 & \mathbf{3 8} & 48 \\ & & & & & & & \\ & & & & & & & \\ 27 & 30 & 29 & 30 & 31 & 32 & \mathbf{3 9} & 48 \\ 27 & 33 & 43 & 43 & 44 & 45 & \mathbf{5 0} & 50 \\ 27 & 32 & 33 & 33 & 34 & 36 & \mathbf{4 3} & 53 \\ 27 & 36 & 42 & 41 & 43 & 44 & \mathbf{4 8} & 48 \\ 27 & 34 & 42 & 42 & 43 & 44 & \mathbf{4 9} & 51 \\ 27 & 42 & 41 & 41 & 43 & 45 & \mathbf{5 4} & 67\end{array}$


Table 3b.Cameroon: Sensitivity Analysis for Key Indicators of Public and Publicly Guaranteed External Debt, 2009-29 (continued) (In percent)

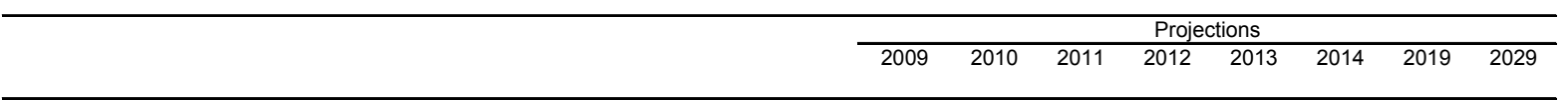

\section{Debt service-to-exports ratio}

\section{Baseline}

\section{A. Alternative Scenarios}

A1. Key variables at their historical averages in $2009-2029^{1}$

A2. New public sector loans on less favorable terms in $2009-2029^{2}$

\section{B. Bound Tests}

B1. Real GDP growth at historical average minus one standard deviation in 2010-2011

B2. Export value growth at historical average minus one standard deviation in 2010-2011

B3. US dollar GDP deflator at historical average minus one standard deviation in 2010-2011

B4. Net non-debt creating flows at historical average minus one standard deviation in 2010-2011 ${ }^{4}$

B5. Combination of B1-B4 using one-half standard deviation shocks

B6. One-time 30 percent nominal depreciation relative to the baseline in $2010^{5}$

\section{Debt service-to-revenue ratio}

\section{Baseline}

\section{A. Alternative Scenarios}

A1. Key variables at their historical averages in $2009-2029^{1}$

A2. New public sector loans on less favorable terms in $2009-2029^{2}$

\section{B. Bound Tests}

B1. Real GDP growth at historical average minus one standard deviation in 2010-2011

B2. Export value growth at historical average minus one standard deviation in 2010-2011

B3. US dollar GDP deflator at historical average minus one standard deviation in 2010-2011

B4. Net non-debt creating flows at historical average minus one standard deviation in 2010-2011 ${ }^{4}$

B5. Combination of B1-B4 using one-half standard deviation shocks

B6. One-time 30 percent nominal depreciation relative to the baseline in $2010^{5}$

Memorandum item:

Grant element assumed on residual financing (i.e., financing required above baseline) ${ }^{6}$

$\begin{array}{llllllll}1 & 1 & 1 & 1 & 1 & 1 & 1 & 2 \\ 1 & 1 & 1 & 1 & 1 & 1 & 1 & 3 \\ 1 & 1 & 1 & 1 & 1 & 1 & 2 & 2\end{array}$

3

Source: Staff projections and simulations.

${ }^{1}$ Variables include real GDP growth, growth of GDP deflator (in U.S. dollar terms), non-interest current account in percent of GDP, and non-debt creating flows.

${ }^{2}$ Assumes that the interest rate on new borrowing is by 2 percentage points higher than in the baseline., while grace and maturity periods are the same as in the baseline.

${ }^{3}$ Exports values are assumed to remain permanently at the lower level, but the current account as a share of GDP is assumed to return to its baseline level after the shock (implicitly assuming an offsetting adjustment in import levels).

${ }^{4}$ Includes official and private transfers and FDI.

${ }^{5}$ Depreciation is defined as percentage decline in dollar/local currency rate, such that it never exceeds 100 percent.

${ }^{6}$ Applies to all stress scenarios except for A2 (less favorable financing) in which the terms on all new financing are as specified in footnote 2. 


\section{INTERNATIONAL MONETARY FUND}

\section{CAMEROON}

\section{Staff Report for the 2009 Article IV Consultation and Request for Disbursement Under the Rapid-Access Component of the Exogenous Shocks Facility \\ Informational Annex}

\section{Prepared by the African Department}

Approved by Mark Plant and Dhaneshwar Ghura

June 19, 2009

Contents

Page

I. Relations with the Fund $\underline{2}$

II. Bank-Fund Joint Managerial Action Plan, 2009-10 ………………............................. $\underline{8}$

III. Table of Common Indicators Required for Surveillance 


\section{RELATIONS WITH THE FUND}

(As of May 31, 2009)

I. Membership Status: Joined 07/10/1963; Article VIII

II. General Resources Account:

Quota

Fund holdings of currency

Reserve position in Fund

III. SDR Department:

Net cumulative allocation

Holdings

IV. Outstanding Purchases and Loans:

PRGF arrangements $\underline{\text { SDR million }}$

185.70

184.88

0.83

$\underline{\text { SDR million }}$

24.46

2.96

$\underline{\text { SDR million }}$

18.57
\%Quota

100.00

99.56

0.45

\%Allocation

100.00

12.09

\%Quota

10.00

V. Latest Financial Arrangements:

$\begin{array}{ccccc}\underline{\text { Type }} & \begin{array}{c}\text { Arrangement } \\ \text { Araf }\end{array} & \begin{array}{c}\text { Expiration } \\ \text { date }\end{array} & \begin{array}{c}\text { Amount approved } \\ \text { (SDR million) }\end{array} & \begin{array}{c}\text { Amount drawn } \\ \text { (SDR million) }\end{array} \\ \text { PRGF } & 10 / 24 / 2005 & 01 / 31 / 2009 & 18.57 & 18.57 \\ \text { PRGF } & 12 / 21 / 2000 & 12 / 20 / 2004 & 111.42 & 79.59 \\ \text { PRGF } & 08 / 20 / 1997 & 12 / 20 / 2000 & 162.12 & 162.12\end{array}$


VI. Projected Payments to Fund (SDR million; based on existing use of resources and present holdings of SDRs):

\begin{tabular}{lccccc} 
& \multicolumn{5}{c}{ Forthcoming } \\
\cline { 2 - 6 } & $\underline{\underline{2009}}$ & $\underline{\underline{2010}}$ & $\underline{\underline{2011}}$ & $\underline{\underline{2012}}$ & $\underline{\underline{2013}}$ \\
Principal & & & 0.80 & 1.59 & 2.39 \\
Charges/interest & 0.14 & 0.19 & 0.19 & 0.19 & 0.18 \\
Total & 0.14 & 0.19 & 0.99 & 1.78 & 2.56
\end{tabular}

VII. Implementation of HIPC Initiative:

Enhanced

framework

I. Commitment of HIPC assistance

Decision point date

Oct. 2000

Assistance committed ${ }^{1}$

By all creditors (US\$ million)

Of which: Fund assistance (US\$ million)

$1,267.00$

(SDR equivalent in millions)

28.62

Completion point date

Apr. 2006

II. Delivery of Fund assistance (SDR million)

Amount disbursed

Interim assistance

11.25

Completion point

Additional disbursement of interest income ${ }^{2}$

Total disbursements

33.67

\footnotetext{
${ }^{1}$ Assistance committed under the original framework is expressed in net present value (NPV) terms at the completion point, and assistance committed under the enhanced framework is expressed in NPV terms at the decision point. Hence these two amounts cannot be added.

${ }^{2}$ Under the enhanced framework, an additional disbursement is made at the completion point corresponding to interest income earned on the amount committed at the decision point but not disbursed during the interim period.
} 
VIII. Implementation of MDRI Assistance:

I. MDRI-eligible debt (SDR million) ${ }^{1} \quad 173.26$

Financed by: MDRI Trust $\quad 149.17$

Remaining HIPC Resources $\quad 24.09$

II. Debt Relief by Facility (SDR million)

Eligible Debt

$\begin{array}{llll}\frac{\text { Delivery }}{\text { Date }} & \text { GRA } & \frac{\text { PRGF }}{173.26} & \frac{\text { Total }}{173.26} \\ \text { April 2006 } & \text { N/A } & \end{array}$

${ }^{1}$ The MDRI provides 100 percent debt relief to eligible member countries that qualified for the assistance. Grant assistance from the MDRI Trust and HIPC resources provide debt relief to cover the full stock of debt owed to the Fund as of end-2004 that remains outstanding at the time the member qualifies for such debt relief.

\section{Safeguards Assessments:}

The Bank of the Central African States (BEAC) is the regional central bank of the Central African States. The most recent safeguards assessment of the BEAC was completed on August 30, 2004. The assessment found that the Bank has implemented a number of measures to strengthen its safeguards framework since the 2001 safeguards assessment, and recommended further enhancements in the areas of external and internal audits, and financial reporting. Latest monitoring results indicate the existence of certain vulnerabilities including in the system of internal controls. These and other aspects of the BEAC safeguards framework will be reviewed in the context of the 2008 update safeguards assessment of BEAC that is underway.

\section{Exchange Arrangements:}

Cameroon participates in a currency union with five other members of the CEMAC and has no separate legal tender. Cameroon's currency, the CFA franc, is pegged to the euro at the fixed rate of CFAF 655.957 per euro. Local currency equivalent: CFAF 729=SDR 1, as of June 17, 2009. Effective January 1, 2007, the exchange arrangement of the CEMAC countries has been reclassified to the category of conventional pegged arrangement from the category of exchange arrangement with no separate legal tender. The new classification is based on the behavior of the common currency, whereas the previous classification was based on the lack of a separate legal tender. The new classification thus reflects only a definitional change, and is not based on a judgment that there has been a substantive change in the exchange regime or other policies of the currency union or its members. 
Cameroon maintains an exchange system free of restrictions on the making of payments and transfers for current international transactions, except for restrictions maintained for security reasons that have been notified to the Fund pursuant to Executive Board decision 144-152/51.

\section{Article IV Consultation:}

The last Article IV consultation with Cameroon was concluded by the Executive Board on June 18, 2007.

An Article IV consultation mission visited Yaoundé, Cameroon during March 26-April 9, 2009.

\section{FSAP Participation and ROSCs:}

The Financial System Stability Assessment (FSSA) report of May 24, 2000 is based on the findings of the joint IMF-World Bank mission that visited Cameroon during February 29-March 14, 2000. The findings of the Financial Sector Assessment Program (FSAP) mission were presented to the authorities on March 13-14, 2000 in the context of the 2000 Article IV consultation. An updated assessment was carried out by a joint IMF-World Bank FSAP mission in June 2007.

The Report on the Observance of Standards and Codes (ROSC) on fiscal transparency and transparency of monetary and financial policies was issued on June 16, 2000.

The data module of the ROSC was issued on August 24, 2001 (CR/01/150).

A fiscal ROSC reassessment mission visited Yaoundé, Cameroon during May 6-18, 2009.

\section{Technical Assistance:}

November 2008: FAD mission on customs administration.

June 2008: $\quad$ MCM mission (jointly with World Bank) on debt management strategy.

May 2008: $\quad$ FAD mission on the implementation of the new public finance system law.

April 2008: $\quad$ FAD mission on tax administration.

October 2006: FAD mission on poverty and social impact assessment of the current petroleum price mechanism. 
October 2006: FAD mission (jointly with World Bank) to assess preparation of the new organic budget law, and review expenditure classification system.

March 2006: $\quad$ STA mission on balance of payments statistics compilation.

September 2005: Placement of an FAD resident expert for fiscal administration (shared with other countries in the region).

July 2005: $\quad$ FAD mission on tax policy.

May 2005: $\quad$ FAD mission on tax and customs administration.

December 2004: STA mission on the compilation of national accounts and follow-up by FAD expert on public expenditure management.

October 2003: $\quad$ STA mission on the compilation of national accounts.

September 2003: FAD mission on non-oil revenue mobilization and follow-up by FAD expert on public expenditure management.

June 2003: $\quad$ FAD mission on public expenditure management.

March 2003: $\quad$ FAD mission on public expenditure management.

November 2002: FAD mission on public expenditure management.

May 2002: $\quad$ FAD mission on public expenditure management.

April 2002: $\quad$ FAD mission follow-up on the personal income tax system.

March 2002: $\quad$ FAD mission on the implementation of the action plan for government revenue and expenditure.

October-

November 2001: FAD mission on tax and customs administration.

September 2001: FAD missions on the audit of the treasury and poverty tracking.

June 2000: $\quad$ FAD mission on the modernization of customs.

April 2000: $\quad$ STA mission on General Data Dissemination System (GDDS/ROSC). 
November 1999: FAD mission on modernization of the tax department.

June-July 1999: FAD mission on customs.

May-June 1999: FAD follow-up mission on value-added tax (VAT) and tax administration.

January-

March 1999: $\quad$ Placement of an FAD advisor for the introduction of the VAT.

November 1998: Placement of an FAD resident advisor on public expenditure management.

October-

November 1998: STA mission on metadata project.

September 1998: Placement of FAD advisor for the VAT.

July 1998: $\quad$ FAD mission on preparation of a VAT.

February 1998: FAD mission on review of public expenditure management.

November 1997: FAD mission on preparation for the introduction of the VAT.

January-

February 1997: AFR/PDR mission, in collaboration with experts from the World Bank and the French government, on external debt statistics.

May 1996: $\quad$ AFR mission, in collaboration with a team from the French Treasury and the Banque de France, on the system of fiscal reporting and monitoring.

February 1996: FAD mission on direct taxation and agricultural sector taxation.

May-June 1995: STA mission on balance of payments statistics.

XIV. Resident Representatives:

The post of IMF Resident Representative has been maintained in Yaoundé continuously since 1989. The current Resident Representative, Ms. Kabedi-Mbuyi, has been in her post since July 2005. 


\section{BANK-Fund JoINt MANAgerial ACtion PLAN, 2009-10}

\begin{tabular}{|c|c|c|c|}
\hline \multicolumn{2}{|l|}{ Products } & Mission timing & Expected delivery \\
\hline \multicolumn{4}{|c|}{ A. Mutual information on relevant work programs } \\
\hline \multicolumn{4}{|l|}{ The Fund work program } \\
\hline \multicolumn{4}{|c|}{$\begin{array}{l}\text { Strategy: Fund's policy advice and technical assistance will focus on helping Cameroon preserve fiscal sustainability and } \\
\text { economic stability, while expanding priority spending to accelerate growth and poverty reduction. }\end{array}$} \\
\hline $\begin{array}{l}2009 \text { Article IV consultation and } \\
\text { request for an ESF-RAC }\end{array}$ & \multicolumn{2}{|c|}{ March-April 2009} & Board discussion in early July 2009 \\
\hline Public debt management & \multicolumn{2}{|c|}{ September 2009} & $\begin{array}{l}\text { Aide-mémoire at the end of the } \\
\text { mission }\end{array}$ \\
\hline Strengthening revenue administration & \multicolumn{2}{|c|}{$\begin{array}{l}\text { Three missions: September 2009; } \\
\text { November 2009; and February } 2010\end{array}$} & $\begin{array}{l}\text { Aide-mémoire at the end of the } \\
\text { mission }\end{array}$ \\
\hline $\begin{array}{l}\text { Implementation of new public finance } \\
\text { law }\end{array}$ & \multicolumn{2}{|c|}{ October 2009} & $\begin{array}{l}\text { Aide-mémoire at the end of the } \\
\text { mission }\end{array}$ \\
\hline National account statistics & \multicolumn{2}{|c|}{ December 2009} & $\begin{array}{l}\text { Aide-mémoire at the end of the } \\
\text { mission }\end{array}$ \\
\hline \multicolumn{4}{|l|}{ The World Bank program } \\
\hline \multicolumn{4}{|c|}{$\begin{array}{l}\text { Strategy: The new Country Assistance Strategy will aim at improving governance and accelerating growth and productive } \\
\text { employment. To complement fiscal consolidation and improved public financial management, the Bank will support the } \\
\text { government in removing bottlenecks to growth and development, including improving business climate, increasing energy } \\
\text { supply, and addressing constraints to agriculture development. }\end{array}$} \\
\hline \multicolumn{2}{|l|}{ Country Assistance Strategy } & September 2008 & Board presentation by September 2009 \\
\hline \multicolumn{2}{|l|}{ Private sector development (lending, TA) } & $\begin{array}{l}\text { Two missions: dates to be } \\
\text { decided }\end{array}$ & $\begin{array}{l}\text { Aide-mémoire and Board presentation by } \\
\text { December } 2009\end{array}$ \\
\hline \multicolumn{2}{|l|}{$\begin{array}{l}\text { Electricity sector development (Partial Risk } \\
\text { Guarantee, TA) }\end{array}$} & $\begin{array}{l}\text { One mission: date to be } \\
\text { decided }\end{array}$ & $\begin{array}{l}\text { Aide-mémoire and Board presentation by } \\
\text { September } 2009\end{array}$ \\
\hline \multicolumn{2}{|l|}{$\begin{array}{l}\text { Transparency and accountability capacity } \\
\text { building: TA and policy dialogue }\end{array}$} & $\begin{array}{l}\text { Two missions: dates to be } \\
\text { decided }\end{array}$ & Aide-mémoire \\
\hline \multicolumn{2}{|l|}{ Urban sanitation (investment operation) } & $\begin{array}{l}\text { Two missions: dates to be } \\
\text { determined }\end{array}$ & $\begin{array}{l}\text { Concept review by September 2009, with } \\
\text { Board presentation before end June } 2010\end{array}$ \\
\hline \multicolumn{2}{|l|}{ Social Protection - analytic work } & $\begin{array}{l}\text { Two missions: dates to be } \\
\text { decided }\end{array}$ & $\begin{array}{l}\text { Concept paper to be circulated before } \\
\text { December } 2009 \text {, with final report for } \\
\text { delivery by end June } 2010\end{array}$ \\
\hline \multicolumn{2}{|c|}{$\begin{array}{l}\text { Supervision and policy dialogue: agriculture, } \\
\text { education, health, environment, forest } \\
\text { reforms, community development programs, } \\
\text { transport, financial sector, water supply and } \\
\text { urban development, infrastructure }\end{array}$} & $\begin{array}{l}\text { Two missions for each } \\
\text { sector/theme }\end{array}$ & Aide-mémoire \\
\hline \multicolumn{4}{|c|}{ B. Requests for work program inputs } \\
\hline \multicolumn{4}{|l|}{ Fund request to Bank } \\
\hline \multicolumn{4}{|l|}{ Periodic update on progress } \\
\hline \multicolumn{4}{|l|}{ Bank request to Fund } \\
\hline \multicolumn{4}{|l|}{ Periodic macro update } \\
\hline \multicolumn{4}{|c|}{ C. Agreement on joint products and missions } \\
\hline DSA update & & March-April 2009 & Board discussion in July 2009 \\
\hline
\end{tabular}




\section{TABLE OF COMMON INDICATORS REQUIRED FOR SURVEILLANCE}

(As of May 31, 2009)

\begin{tabular}{|c|c|c|c|c|c|}
\hline & $\begin{array}{c}\text { Date of } \\
\text { latest } \\
\text { observation }\end{array}$ & $\begin{array}{l}\text { Date } \\
\text { received }\end{array}$ & $\begin{array}{c}\text { Frequency } \\
\text { of } \\
\text { data }^{1}\end{array}$ & $\begin{array}{l}\text { Frequency } \\
\text { of } \\
\text { reporting }\end{array}$ & $\begin{array}{l}\text { Frequency of } \\
\text { publication }^{1}\end{array}$ \\
\hline Exchange rates & March 2009 & April 2009 & M & M & M \\
\hline $\begin{array}{l}\text { International reserve assets and reserve } \\
\text { liabilities of the monetary authorities }{ }^{2}\end{array}$ & March 2009 & April 2009 & M & M & M \\
\hline Reserve/Base money & March 2009 & April 2009 & M & M & M \\
\hline Broad money & March 2009 & April 2009 & M & M & M \\
\hline Central bank balance sheet & March 2009 & April 2009 & M & M & M \\
\hline $\begin{array}{l}\text { Consolidated balance sheet of the banking } \\
\text { system }\end{array}$ & March 2009 & April 2009 & M & M & M \\
\hline Interest rates ${ }^{3}$ & March 2009 & April 2009 & M & M & M \\
\hline Consumer price index & April 2009 & May 2009 & Q & Q & Q \\
\hline $\begin{array}{l}\text { Revenue, Expenditure, Balance and } \\
\text { Composition of financing }{ }^{4}-\text { General } \\
\text { government }^{5}\end{array}$ & NA & NA & NA & NA & NA \\
\hline $\begin{array}{l}\text { Revenue, Expenditure, Balance and } \\
\text { Composition of financing }{ }^{4}-\text { Central } \\
\text { government }\end{array}$ & March 2009 & May 2009 & M & M & $\begin{array}{l}\text { Partial data } \\
\text { published } \\
\text { monthly }\end{array}$ \\
\hline $\begin{array}{l}\text { Stocks of central government and Central } \\
\text { government-guaranteed debt }\end{array}$ & March 2009 & May 2009 & M & M & M \\
\hline External current account balance & 2007 & Feb. 2008 & A & A & NA \\
\hline Exports and imports of goods and services ${ }^{7}$ & Dec. 2008 & April 2009 & M & M & NA \\
\hline GDP/GNP & Dec. 2007 & Feb. 2008 & A & A & NA \\
\hline Gross external debt & Dec. 2008 & April 2009 & A & A & A \\
\hline International investment position & NA & NA & NA & NA & NA \\
\hline
\end{tabular}

${ }^{1}$ Monthly (M), Quarterly (Q), Annually (A), and Not Available (NA).

${ }^{2}$ Includes reserve assets pledged or otherwise encumbered as well as net derivative positions.

${ }^{3}$ Both market-based and officially determined, including discount rates, money market rates, rates on treasury bills, notes and bonds.

${ }^{4}$ Foreign, domestic bank, and domestic nonbank financing.

${ }^{5}$ The general government consists of the central government (budgetary funds, extra budgetary funds, and social security funds) and state and local governments.

${ }^{6}$ Including currency and maturity composition.

${ }^{7}$ Goods only, data on trade in services are not available. 


\section{IMF Executive Board Approves US\$144.1 Million Disbursement for Cameroon Under the Exogenous Shocks Facility}

The Executive Board of the International Monetary Fund (IMF) today approved an SDR 92.85 million (about US\$144.1 million) disbursement under the rapid access component of the Exogenous Shocks Facility (ESF) to help Cameroon weather the effects of the global shocks on its balance of payments. The approval enables the disbursement of the full amount immediately.

The IMF financial assistance will help contain the decline in Cameroon's foreign reserves and ensure that priority outlays (investment, health, and education) are protected.

The ESF is designed to provide policy support and financial assistance to low-income countries facing exogenous but temporary shocks. It is available to countries eligible for the Poverty Reduction and Growth Facility (PRGF) - the IMF's main instrument for financial assistance to low-income countries - but that do not have a PRGF-supported program in place. Financing terms are equivalent to a PRGF arrangement and are more concessional than under other IMF emergency lending facilities.

Following the Executive Board's discussion of Cameroon, Mr. John Lipsky, Deputy Managing Director and Acting Chair, stated:

"The Cameroonian authorities are to be commended for their recent economic achievements. Prudent management of oil windfalls under the recently completed PRGF-supported program has allowed the authorities to accumulate government deposits at the BEAC and contribute to the regional pool of foreign exchange reserves. These savings now provide some welcome buffers that can be used to alleviate the impact of the global crisis.

"The global crisis is however presenting the Cameroonian authorities with a difficult set of challenges. Lower oil prices are reducing exports and fiscal revenues. Considerably weaker external demand is adversely affecting key exports. Tighter external financing conditions have delayed important investment projects. As a result of these sizable shocks, growth is expected to be slower, and the overall fiscal and external balances are projected to turn into a

Washington, D.C. 20431 • Telephone 202-623-7100 • Fax 202-623-6772 • www.imf.org 
deficit. In the absence of appropriate social safety nets, the social costs of the downturn could be severe.

"Against this background, the authorities' efforts to deal with the effects of the crisis with Fund support under the rapid access component of the Exogenous Shocks Facility are welcome. Their commitment to preserve macroeconomic stability and tackle structural impediments to growth will contribute to making the country's economy more resilient in the future.

"The implementation of the 2009 budgetary priority spending plans will help to avoid a public sector contraction in a year of slower economic growth. At the same time, efforts will be stepped up to achieve greater nonoil revenue mobilization and strengthen public expenditure management and transparency. Decisive actions are needed to improve governance, make the business environment more attractive, and enhance the role of the financial sector in the development of the economy. The authorities' commitment to address these challenges through a medium-term economic program in the context of a new Poverty Reduction Strategy under preparation is welcome. Although tackling the structural impediments to faster growth will be more challenging in a crisis environment, it will put the country on a stronger footing to reduce poverty in a sustainable way.

"Continued vigilance will be required against downside risks to the financial sector, which could be negatively affected by a protracted economic slowdown. Close monitoring of developments in cooperation with regional supervisors will help ensure that corrective actions are taken as needed," added Mr. Lipsky. 


\section{Statement by Laurean W. Rutayisire, Executive Director for Cameroon}

\section{July 2, 2009}

On behalf of my Cameroonian authorities, I would like to convey my appreciation to the Executive Board and Management for their continued support to Cameroon's efforts to achieve sustained growth and economic development. I would also like to communicate my authorities' appreciation to staff for their constructive policy dialogue and fruitful exchanges in general and their recent visit to Yaoundé in the context of Article IV Consultations in particular.

Cameroon's macroeconomic performance was strengthened under the last PRGF arrangement, which was completed in January 2009. Debt relief in 2006 under the HIPC Initiative and the MDRI, coupled with prudent borrowing policies since that year, helped bring and maintain the country's debt to a sustainable level and create some fiscal space for poverty-reducing spending. Prudent fiscal policy allowed a significant building up of government deposits and an increase in Cameroon's international reserves at the regional central bank (BEAC), while enabling the authorities to raise investment and normalize relations with creditors. At the same time, thanks to appropriate fiscal measures, the authorities have succeeded to contain the social tensions that arose last year following food and fuel price shocks.

Despite these important achievements, Cameroon's economy remains vulnerable to exogenous shocks, and the current global economic crisis is now compounding these vulnerabilities. Lower oil proceeds, reduced exports and fiscal revenues along with tighter financing conditions are delaying important investment projects and threatens employment in key sectors, notably forestry and agriculture. As a result, growth projections, both this year and in the medium-term, have been revised downward; the overall fiscal balance is projected to turn into deficit; and the current account deficit will widen and remain large over the medium-term.

Against this background, my authorities have already taken steps to deal with the current shock, in particular by maintaining the 2009 budgetary priority spending plans to avoid public sector contraction in a year of declining economic growth. This crisis is emerging barely one year after the food and oil price shocks that provoked nationwide strikes and led to catastrophic destruction of properties. My authorities want to act early and proactively in order to avoid a similar situation. Thus, they are requesting assistance under the Exogenous Shocks Facility (ESF). Given the balance of payments financing needs in 2009 resulting from the global economic crisis, my authorities are requesting a disbursement of 50 percent of quota under the Rapid Access Component (RAC) of the ESF. 


\section{IMPACT OF THE CRISIS AND POLICY RESPONSE}

\section{Impact of the Global Economic Crisis}

The global financial crisis has started to affect the Cameroonian economy and is expected to have a greater impact going further into 2009, notably through declining commodity prices, slower external demand for some of the country's main export commodities (cotton, aluminum, timber, rubber), tight financing conditions and lower remittances. As a result, economic activity is projected to slow by 1 percentage point to 2.4 percent in 2009 . The external and fiscal position will also be affected. Absent additional financing, foreign exchange reserves as coverage for imports would decline sharply. The medium-term economic outlook has also been revised downward, as delays in implementing important infrastructure projects will continue to hamper economic growth. In this context, the key challenge facing my authorities is to address the impact of the global crisis within a framework that maintains fiscal and external sustainability, while leaving room to boost growth. That is why they are responding with adequate policy measures while requesting rapid assistance under the ESF.

\section{Policy Response}

To deal with the crisis, my authorities will use fiscal space to boost the economy, while containing the overall fiscal deficit. In this regard, they are preparing a supplementary budget which would allow for some targeted support, a minor increase in domestic investment and a larger allocation for the clearance of arrears, while maintaining the initially planned priority outlays to support economic growth. In this context, my authorities intend to eliminate subsidies on fuel prices and resume implementation of the mechanism for adjusting petroleum prices. To protect the most vulnerable segments of the population, the authorities will strengthen social safety nets and provide assistance to sectors in distress, particularly in order to help small producers in the timber and cotton sectors and provide input subsidies to the agriculture sector. Should downside risks materialize, my authorities are prepared to consider contingent measures to ensure fiscal consolidation.

The authorities are also responding to the crisis by implementing a medium-term threepronged strategy aimed at reducing the vulnerability of the economy to exogenous shocks while maintaining macroeconomic stability. The first pillar of this strategy consists of stepping up efforts to increase nonoil revenue through expanding tax revenues to make up for declining oil receipts and the upcoming reduction of external tariffs. As regards internal revenue, the authorities will simplify tax procedures to improve compliance, tighten tax exemptions, finalize the computer connection between the ministry of Finance and the ministry of Forestry, and update the fiscal cadastre in order to expand the property tax base. Concerning customs, the authorities will enhance data sharing in the electronic one-stop shop and improve computerized systems to combat fraud. They will also strengthen the tracking system for merchandise, in particular for imported tobacco and alcohol.

The second pillar is to improve public expenditure management, in order to achieve savings that can be reallocated to priority outlays. In this regard, the authorities will undertake a 
quarterly revision of the reference prices for government orders to strengthen the effectiveness of public spending. At the same time, they will step up capital spending to reduce the severe infrastructure bottlenecks and provide renewed impetus for growth. They will also improve fiscal transparency by publishing the quarterly reports on budget execution and, more broadly, by implementing the new public finance system law which introduces more stringent accounting and control rules.

The third pillar is to develop alternative sources of domestic financing by working with relevant regional agencies and taking measures to speed up the development of the domestic bond market, while strengthening the debt management capacity to preserve Cameroon's sustainable debt profile.

\section{OTHER MEDIUM-TERM REFORMS}

Beyond the fiscal policies and reforms laid out above, my authorities strive to reduce impediments to stronger growth by promoting a healthy and stable financial sector and ensuring an investment climate conducive to the expansion of the private sector.

\section{Financial Sector}

To assure the stability of the financial sector, my authorities will continue to work with the relevant regional authorities to strengthen surveillance of the banking system, ensure adequate provisions against nonperforming loans, enforce corrective actions in bank regulatory compliance where needed, and limit any potential cost to the budget. At the same time, they intend to accelerate the implementation of measures to deepen financial intermediation by improving credit information, setting up a court dedicated to commercial matters and settlements, and introducing financial instruments for SMEs.

\section{Growth-oriented Structural Reforms}

My authorities are committed to stepping up efforts to accelerate economic growth. In this vein, priority will be given to private sector development to expand and diversify the production base, in order to help reduce the vulnerability of the economy to exogenous shocks.

In this endeavor, the authorities have initiated dialogue with the private sector and development partners to identify concrete measures to improve the business environment and streamline procedures for establishing companies. The authorities are also putting emphasis on improving governance and combating corruption, building on the progress achieved in recent years.

My authorities are cognizant that further progress in reforming public enterprises would also help improve the business environment. They are taking steps to clarify reform strategies in the telecommunications and air transport sectors and prepare for a new impetus to the privatization program once international financial conditions improve. 
The authorities are also planning further trade liberalization efforts, in order to stimulate economic growth. In this context, they will continue to work with their regional partners to further liberalize intra-CEMAC trade and finalize the regional economic partnership with the EU.

\section{CONCLUSION}

My Cameroonian authorities have continued to make good progress in the implementation of reforms in spite of a difficult international environment. To pursue their structural agenda, my Cameroonian authorities intend to move rapidly to a new PRGF arrangement articulated around the new PRSP which is being finalized, and they have initiated discussions with other multilateral partners for additional financing. In the meantime, Cameroon is facing immediate financing needs due to the global economic crisis. In view of the magnitude of the shock, the resulting balance of payments needs, my Cameroonian authorities' commitment to maintain sound policies going forward, coupled with the country's capacity to repay the Fund, I would appreciate the Board's support to my authorities' request for disbursement under the Rapid Access Component of the ESF. 